UNIVERSIDADE ESTADUAL PAULISTA “JÚLIO DE MESQUITA FILHO” FACULDADEDECIÊNCIAS AGRONÔMICAS CAMPUSDEBOTUCATU

\title{
DESENVOLVIMENTO DE UMA BASE DE DADOS DE IMAGENS DIGITAIS DE MADEIRA SERRADA DE CONÍFERAS
}

\author{
ROGER CRISTHIAN GOMES
}

Dissertação apresentada à Faculdade de Ciências Agronômicas da UNESP - Campus de Botucatu, para obtenção do título de Mestre em Agronomia (Programa de Pós-Graduação em Agronomia - Energia na Agricultura). 
UNIVERSIDADEESTADUAL PAULISTA “JÚLIO DE MESQUITA FILHO”

FACULDADEDECIÊNCIAS AGRONÔMICAS

CAMPUSDEBOTUCATU

\section{DESENVOLVIMENTO DE UMA BASE DE DADOS DE IMAGENS \\ DIGITAIS DE MADEIRA SERRADA DE CONÍFERAS}

\section{ROGER CRISTHIAN GOMES}

Orientador: Prof. Dr. Adriano Wagner Ballarin

Dissertação apresentada à Faculdade de Ciências Agronômicas da UNESP - Campus de Botucatu, para obtenção do título de Mestre em Agronomia (Programa de Pós-Graduação em Agronomia - Energia na Agricultura). 
FICHA CATALOGRÁFICA ELABORADA PELA SEÇÃO TÉCNICA DE AQUISIÇÃO E TRATAMENTO DA INFORMAÇÃO - SERVIÇO TÉCNICO DE BIBLIOTECA E DOCUMENTAÇA̧O - UNESP - FCA - LAGEADO - BOTUCATU (SP)

Gomes, Roger Cristhian, 1975-

G633d Desenvolvimento de uma base de dados de imagens digitais de madeira serrada de coníferas / Roger Cristhian Gomes. Botucatu : [s.n.], 2013

x, 95 f. : ils. color., tabs., grafs., fots. color.

Dissertação (Mestrado) - Universidade Estadual Paulista, Faculdade de Ciências Agronômicas, Botucatu, 2013

Orientador: Adriano Wagner Ballarin

Inclui bibliografia

1. Madeira serrada. 2. Conífera. 3. Madeira - Classificação. 4. Madeira - Base de dados. I. Ballarin, Adriano Wagner. II. Universidade Estadual Paulista "Júlio de Mesquita Filho" (Campus de Botucatu). Faculdade de Ciências Agronômicas. III. Título. 
UNIVERSIDADE ESTADUAL PAULISTA “JÚLIO DE MESQUITA FILHO” FACULDADE DE CIÊNCIAS AGRONÔMICAS

CAMPUS DE BOTUCATU

CERTIFICADO DE APROVAÇÃO

TÍTULO: "DESENVOLVIMENTO DE UMA BASE DE DADOS DE IMAGENS DIGITAIS DE MADEIRA SERRADA DE CONÍFERAS"

ALUNO: ROGER CRISTHIAN GOMES

ORIENTADOR: PROF. DR. ADRIANO WAGNER BALLARIN

Aprovado pela Comissão Examinadora
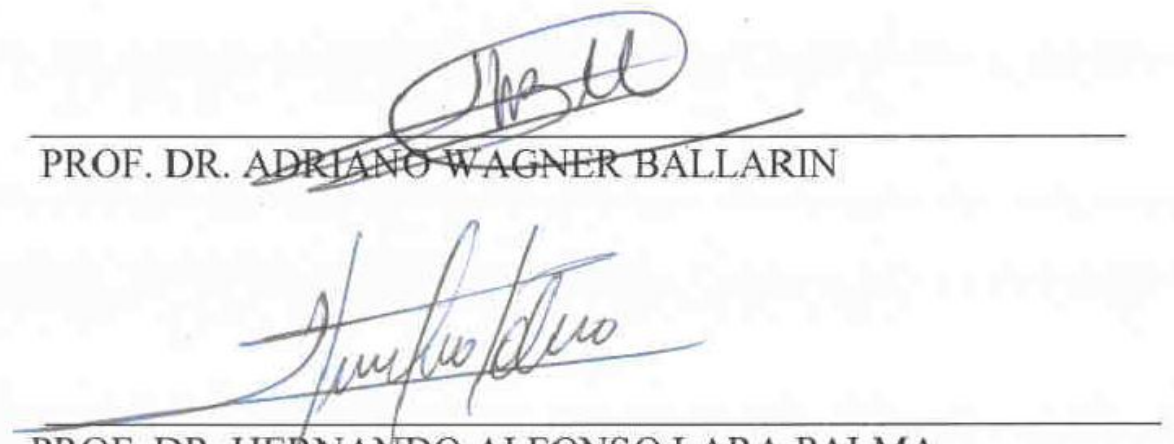

PROF. DR. HERNANDO ALFONSO LARA PALMA

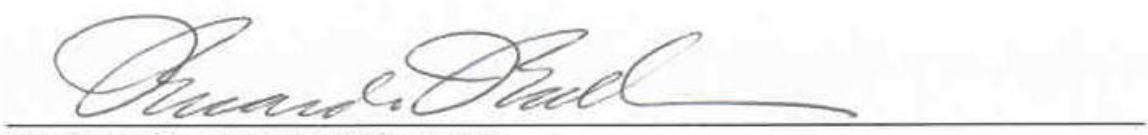

PROF. DR. RICARDO RALL

Data da Realização: 16 de agosto de 2013 


\section{DEDICATÓRIA}

Dedico este trabalho a Deus, que me iluminou nos dias de esforço e falta de inspiração, abrandando meu coração nas atribulações.

Dedico aos meus familiares, em especial a minha eterna companheira Ângela que, diante de tudo, sempre me apóia.

Dedico a minha filha Ana Alice, que um dia entenderá esse esforço e passará pela mesma experiência que estou passando, sendo essa uma forma de incentivo. 


\section{AGRADECIMENTOS}

Em primeiro lugar agradeço ao professor Dr. Adriano Wagner Ballarin, por ter acreditado em minha capacidade e ter me aceitado como orientado. E acima de tudo por ter me apoiado em todas as situações sendo, mais que um orientador, um amigo. A ele toda minha admiração, amizade, consideração e respeito.

Meus sinceros agradecimentos aos professores Dr. Hernando Alfonso Lara Palma e ao professor Dr. Ricardo Rall, pela ajuda nos trabalhos efetuados no Horto Florestal de Manduri - SP, além das contribuições em outros aspectos do desenvolvimento desse trabalho. Agradeço ainda por participarem de minha banca de qualificação contribuindo com pertinentes e valiosas sugestões dadas na ocasião.

Agradeço de coração meu amigo Osvaldo Cesar Pinheiro de Almeida por toda ajuda despendida no desenvolvimento do sistema web. E por todas as suas contribuições em discussões sobre o trabalho como um todo. Agradeço também a sua esposa Raquel, que por diversas vezes nos preparou um café em nossas reuniões para nos dar ânimo e também me incentivou muito.

Também agradeço a todos os colegas de sala de aula de mestrado e aos professores das disciplinas que muito contribuíram para minha formação, também a todas as pessoas que me acompanharam nesse longo período e que, de alguma forma, me apoiaram nesta empreitada.

A todos os funcionários do Horto florestal de Manduri - SP que ajudaram no desdobro das arvores em toras e tábuas e no processo de aquisição das imagens.

À Seção de Pós-Graduação da FCA, por todo o apoio.

Por fim, agradeço aos meus pais por terem me dado todas as condições para que eu pudesse, nesse momento da minha vida, obter tal êxito. 


\section{SUMÁRIO}

Página

LISTA DE TABELAS.................................................................................. VIII

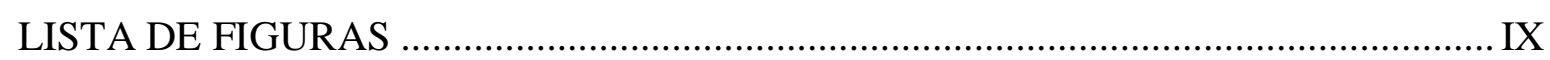

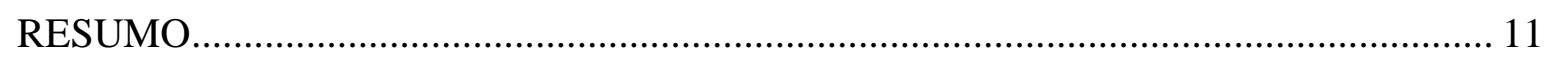

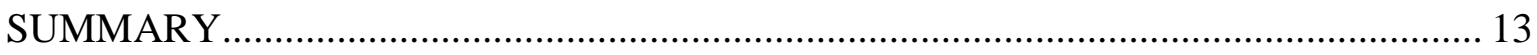

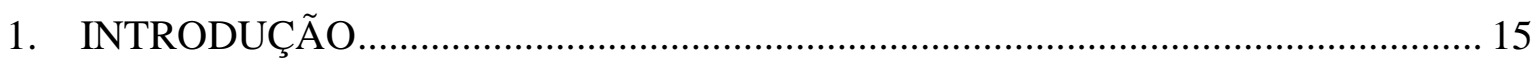

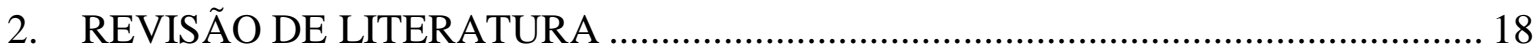

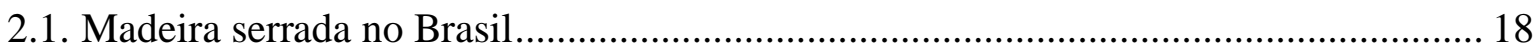

2.2. A madeira de Pinus e as espécies Pinus taeda L. e Pinus elliottii .............................. 19

2.3. Classificação de tábuas de madeira e defeitos........................................................... 21

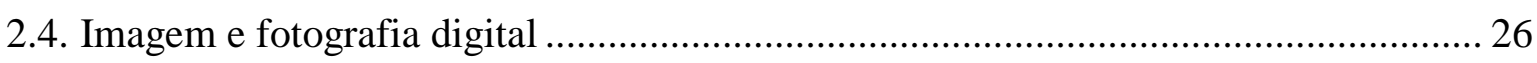

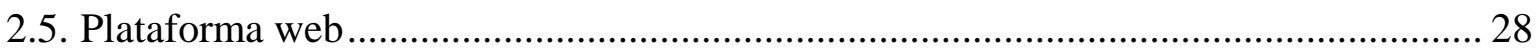

2.6. Modelagem e documentação de banco de dados ........................................................... 29

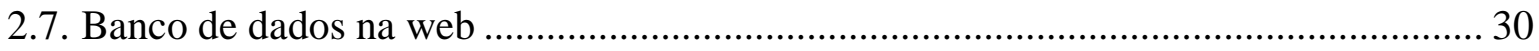

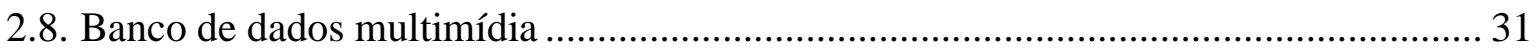

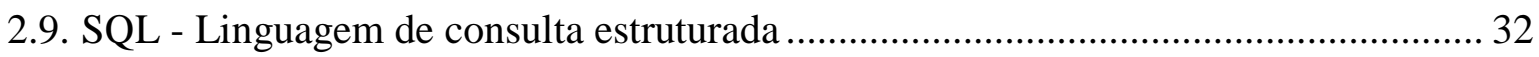

2.10. Sistema de gerenciamento de banco de dados MySQL ...................................... 33

2.11. Desenvolvimento de programas para plataforma web com JAVA....................... 34

2.11.1. Linguagem de programação Java ................................................................. 34

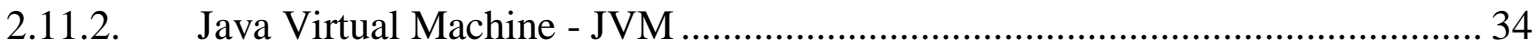

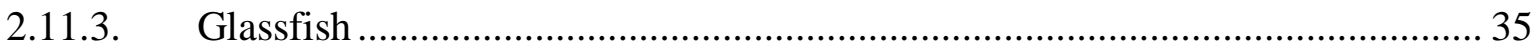

2.11.4. Plataforma de desenvolvimento de software Netbeans IDE 7.2.1 .................. 37

2.11.5. Tecnologias de classificação automatizada de madeira serrada......................... 38

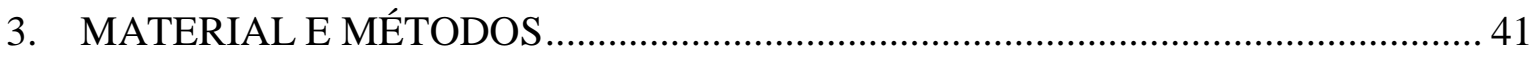

3.1. Geração das imagens digitais e metadados para a base de dados................................ 41

3.1.1. Desdobro das árvores e processamento mecânico das tábuas .............................. 42

3.1.2. Montagem do ambiente para aquisição das imagens .......................................... 46

3.1.3. Aquisição das imagens digitais das tábuas .......................................................... 49

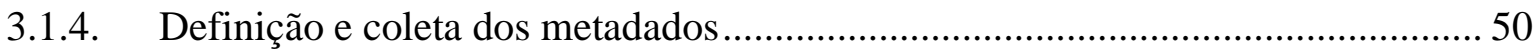

3.1.5. Recorte das regiões pertinentes das imagens ................................................... 51

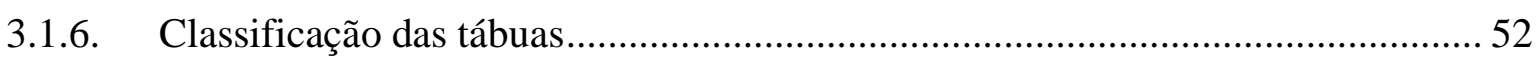


3.1.7. Caracterização das imagens e blocos de defeitos ................................................. 54

3.2. Desenvolvimento do banco de dados de tábuas ......................................................... 54

3.3. Construção e povoamento do banco de dados no SGBD ........................................... 55

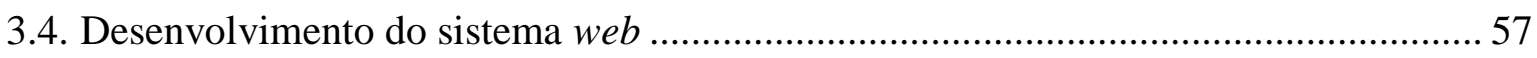

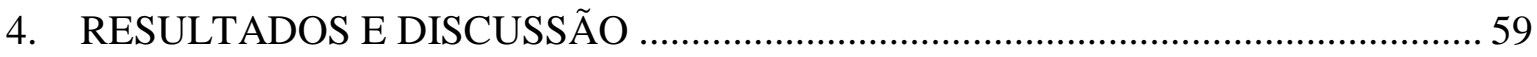

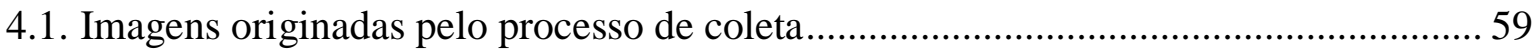

4.2. Classificação das imagens através do software SAIMP ............................................. 61

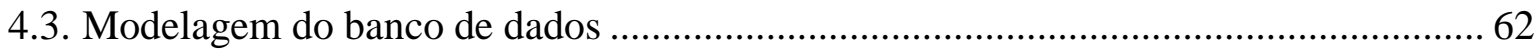

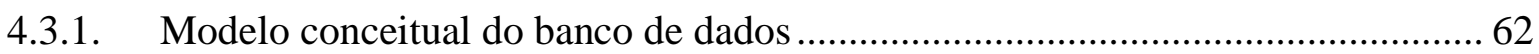

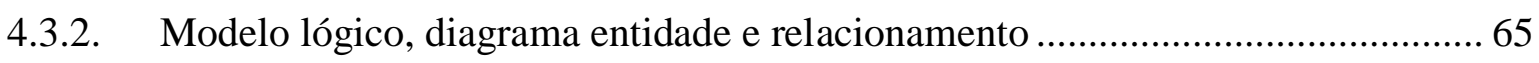

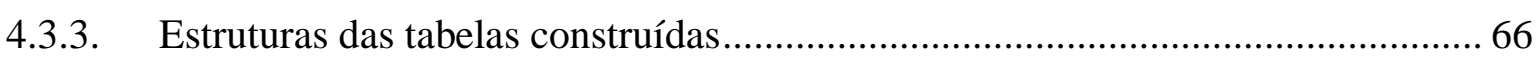

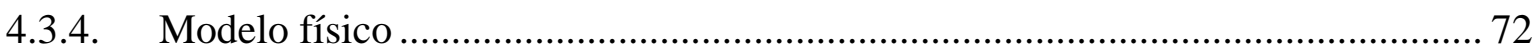

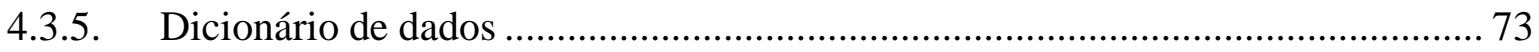

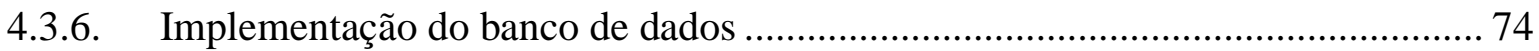

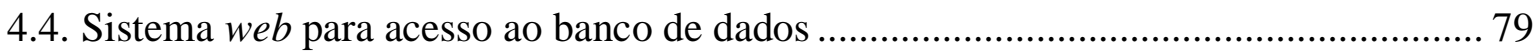

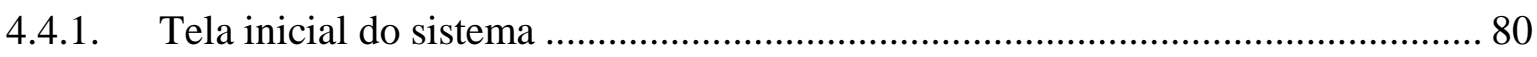

4.4.2. Tela de consulta de imagens e metadados das tábuas ........................................... 81

4.4.3. Tela de detalhamento do resultado da pesquisa .................................................. 82

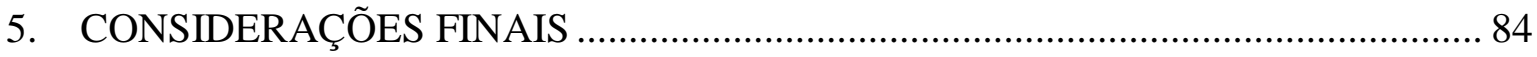

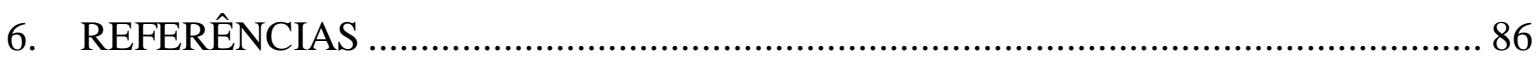

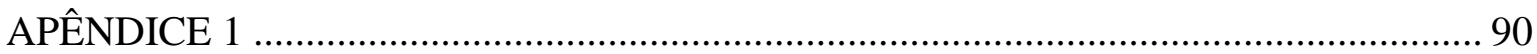

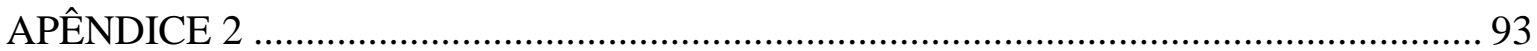




\section{LISTA DE TABELAS}

Página

Tabela 1-Dimensões padronizadas de madeira serrada de coníferas de reflorestamento 19

Tabela 2 - Classificação de madeira serrada de coníferas provenientes de reflorestamento. Compilado por Rall (2010), a partir da norma NBR 11700.

Tabela 3 - Resolução espacial de imagens digitais ......................................................... 27

Tabela 4 - Resumo da quantidade de imagens obtidas por grupo de tábuas....................... 50

Tabela 5 - Classificação das tábuas do grupo 1 ................................................................. 53 


\section{LISTA DE FIGURAS}

Página

Figura 1 - Localização das plantações de Pinus no Brasil................................................ 20

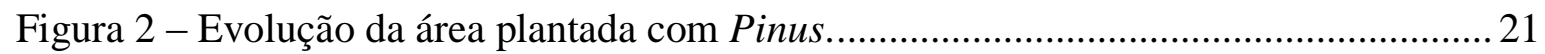

Figura 3 - Principais espécies de Pinus plantadas no Brasil............................................. 21

Figura 4 - a) Defeito caracterizado como nó firme; b) Defeito caracterizado como nó

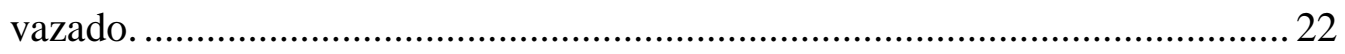

Figura 5 - Defeito caracterizado como bolsa de resina.................................................... 23

Figura 6 - Defeito caracterizado como medula.............................................................. 23

Figura 7 - Presença de nó firme em tábua de classe Super................................................. 24

Figura 8 - Presença de nó vazado em tábua de Terceira classe ........................................ 24

Figura 9 - Etapas para construção e execução de aplicação em linguagem Java. .............. 36

Figura 10 - Arquitetura básica de um servidor de aplicação ........................................... 37

Figura 11 - Vista geral do talhão de Pinus elliottii - Horto Florestal de Manduri............. 43

Figura 12 - Detalhe das toras de 2,5m de comprimento no pátio, para processamento

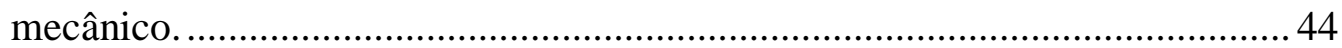

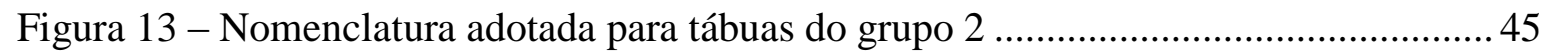

Figura 14 - Processamento mecânico das tábuas do grupo 2. a) vista geral da serra fita dupla. b) detalhe de algumas tábuas desdobradas, antes do refilamento.

Figura 15 - Procedimento de aplainamento das tábuas na carpintaria do Horto Florestal de

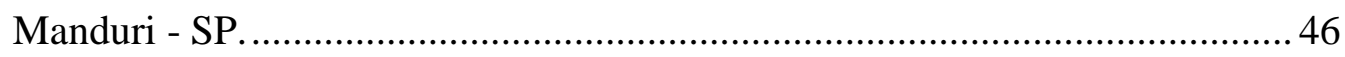

Figura 16 - Estúdio de aquisição de imagens........................................................... 47

Figura 17 - Distribuição dos objetos no estúdio de aquisição de imagens

Figura 18 - Estrutura construída e instalada no ambiente de aquisição de imagens, para suporte e fixação da iluminação artificial. .48

Figura 19 - Esquema da estrutura de suporte da iluminação. ......................................... 48

Figura 20 - Imagem digital original da tábua antes do recorte ......................................52

Figura 21 - Imagem digital após recorte no Microsoft Office Picture Manager .................52

Figura 22 - Tela de implementação do SGBD MySQL ......................................................57

Figura 23 - Imagens das tábuas do grupo 3 após manipulação para armazenamento no banco de dados. 60

Figura 24 - Detalhe de alguns defeitos apresentados nas imagens colhidas. 61 
Figura 25 - Modelo conceitual do banco de dados de tábuas diagramado no software BrModelo

Figura 26 - Diagrama de entidade e relacionamento (DER) construído do software MySQL Workbench. 66

Figura 27 - Estrutura da tabela que receberá metadados e imagens das tábuas 68

Figura 28 - Estrutura da tabela que receberá metadados e imagens dos blocos de defeito 68

Figura 29 - Estrutura da tabela que receberá dados sobre as espécies. 69

Figura 30 - Estrutura da tabela que receberá dados sobre tratamentos aplicados 69

Figura 31 - Estrutura da tabela que receberá dados sobre a região de plantio da árvore .... 70

Figura 32 - Estrutura da tabela que armazenara defeitos catalogados na norma ................ 70

Figura 33 - Estrutura da tabela que armazenara as classes catalogadas na norma ............. 71

Figura 34 - Estrutura da tabela que armazenara dados sobre as árvores de origem das tábuas 71

Figura 35 - Modelo físico do banco de dados de tábuas gerado pelo mysqldump.............. 72

Figura 36 - Dicionário de dados com descrição das tabelas de defeito, espécie e tábua.... 75

Figura 37 - Dicionário de dados com descrição das tabelas de plantio e árvore .76

Figura 38 - Dicionário de dados com descrição das tabelas de tratamento e bloco de defeito

Figura 39 - Dicionário de dados - tabela de tábuas. 78

Figura 40 - Banco de dados sendo desenvolvido no MySQL Workbench

Figura 41 - Tela de processo de desenvolvimento do sistema web no ambiente de desenvolvimento de softwares Netbeans. 80

Figura 42 - Tela inicial do sistema web (home) 81

Figura 43 - Tela de consulta do sistema web 82

Figura 44 - Tela de detalhamento da imagem e download 83 


\section{RESUMO}

A utilização de Pinus proveniente de plantações na indústria madeireira brasileira é expressiva e tem sido crescente nos últimos anos. Particularmente para a madeira serrada desse gênero, utilizada em larga escala na confecção de móveis e estruturas, há a necessidade imperiosa de sua classificação quanto aos defeitos, agravada pelo uso cada vez maior de madeiras advindas de florestas jovens. Essa realidade exige a classificação da madeira serrada quanto à sua qualidade, o que pode ser feito por meio de visão humana (análise visual desempenhada por graduadores humanos) ou de máquina. Essa classificação segue, no Brasil, as normas estabelecidas pela Associação Brasileira de Normas Técnicas (ABNT), porém as mesmas não contemplam, por meio de arquivos digitais, todas as variações que possam surgir nesse campo particular. Promovendo uma pesquisa nos meios digitais constatou-se a falta de material que demonstre, por meio de imagens digitalizadas, os defeitos e variações de defeitos que possam ocorrer durante a classificação visual de peças de madeira serrada de Pinus no dia a dia das serrarias e indústrias que utilizam essa madeira serrada como matéria prima, bem como para os pesquisadores que buscam referências a tais ocorrências em suas pesquisas. Este trabalho teve como objetivo principal a elaboração de uma base de dados de imagens digitais de amostras de madeira serrada de Pinus, apresentando uma gama significativa de defeitos e possíveis variações de defeitos encontrados em madeiras serradas de árvores de reflorestamento. Para o desenvolvimento dessa base de dados de imagens de tábuas de Pinus foram utilizadas árvores do Horto Florestal da cidade de Manduri - SP, sendo desdobradas tábuas, que foram fotografadas em um ambiente preparado (estúdio), em 
diversas etapas de seu beneficiamento (desdobro primário, secagem e aplainamento), gerando um conjunto de 408 imagens de tábuas. As tábuas, por fim, foram classificadas quanto a defeitos (NBR 11700), sendo, adicionalmente, catalogadas imagens isoladas dos principais defeitos. Além da modelagem e implementação do banco de dados, foi desenvolvido um sistema de informação, provido de ferramentas de pesquisas para acesso direto a imagens de tábuas ou defeitos específicos e seus metadados. O banco de dados será hospedado em sítio, para acesso público via internet. $\mathrm{O}$ banco de dados gerado e disponibilizado por sistema de informação específico, com ferramentas de download das imagens e seus dados associados, demonstrou, de imediato, sua utilidade no desenvolvimento de novas tecnologias de classificação automatizada de tábuas, mais baratas e acessíveis que as disponíveis atualmente.

Palavras chave: madeira serrada, tábuas, Pinus, defeitos, classificação, banco de imagens, dados multimídia. 
DEVELOPMENT OF A DATABASE OF CONIFERS SAWNWOOD IMAGES AIMING ITS TECHNOLOGICAL CHARACTERIZATION.

Botucatu, 2013. 97p. Dissertação (Mestrado em Energia da Agricultura) - Faculdade de Ciências Agronômicas, Universidade Estadual Paulista.

Author : ROGER CRISTHIAN GOMES

Adviser: ADRIANO WAGNER BALLARIN

\section{SUMMARY}

The use of pine from plantations in the Brazilian timber industry is significant and has been growing in recent years. Particularly for Pinus lumber, used extensively on making furniture and wooden structures, there is the imperative necessity of its classification for defects, aggravated by the increasing use of wood coming from young forests. This fact requires the classification of lumber for quality, which can be done by human eye (visual analysis performed by human graders) or machine. This classification follows, in Brazil, standards established by Brazilian Association of Technical Standards (ABNT), however they do not include, by means of digital files, all changes that may arise in this particular field. Ulterior research in digital media points the lack of material that present, by means of scanned images, the defects and variations of defects that may occur during the visual grading of sawn wood of Pinus in in-field practice on sawmills and industries, as well as for researchers seeking references to such occurrences in their research. This work aimed the development of a database of digital images of boards of Pinus, showing a significant range of defects and possible variations of defects found in this lumber from reforestation. For the development of this database trees from Horto Florestal city Manduri-SP were sawn into boards, which were photographed in a prepared environment (studio) in various stages of its processing (after primary sawing, drying and planing), generating a set of 382 board pictures. The boards finally were classified for defects (NBR 11700) being additionally cataloged images isolated of its major defects. Besides the modeling and implementation of the database it was also developed an information system, equipped with research tools for direct access to images of boards or specific defects and their 
metadata. The database will be hosted on the site for public access via the Internet. The database generated and made available by information system specific tools to download the images and their associated data, immediately demonstrated its usefulness in the development of new and cheaper technologies for automated classification of boards.

Keywords: sawnwood, boards, Pinus, defects, sorting, image database, multimedia database. 


\section{INTRODUÇÃO}

Em toda pesquisa acadêmica, científica, ou de cunho comercial, o acesso à informação atualizada, confiável e em tempo é primordial. Atualmente os pesquisadores buscam informações não só em bibliografias de referência, onde são garantidas as características da informação como confiabilidade e disponibilidade, mas também nas grandes bases de dados públicas, criadas e gerenciadas por instituições idôneas. Essas bases de dados se beneficiam da infraestrutura da internet, que hoje conta com diversas técnicas de segurança de dados e de rede, que tornam essas pesquisas possíveis e seguras.

Pesquisando sobre a existência de bases de dados pública de imagens digitais de madeira serrada no Brasil, disponíveis para consulta, não foram encontradas nos meios de busca, nem mesmo referência sobre a existência de tais bases. As poucas bases de consulta sobre o assunto não são de imagens digitalizadas, omitem diversas características e, principalmente, informações sobre a classificação da madeira quanto à sua qualidade, sobretudo no quesito defeitos. Essas bases de dados de imagens digitais de madeira serrada seriam particularmente importantes para a madeira de Pinus, por diversos aspectos. Para a ABIMCI (2008) - Associação Brasileira de Madeira Processada Mecanicamente, a principal espécie florestal plantada destinada ao seu processo produtivo é o Pinus (conífera). Além disso, o uso cada vez mais frequente de madeira de florestas jovens, em ciclos mais curtos de produção, tem motivado uma incidência muito grande de defeitos que comprometem a sua qualidade. Ainda segundo a 
ABIMCI (2008), entre os principais produtos fabricados a partir do Pinus destacam-se as lâminas, o compensado, a madeira serrada e os PMVA - produto de maior valor agregado.

A classificação da qualidade da madeira é um importante processo, na produção de madeira serrada. O que pauta essa classificação é, principalmente, a quantidade e tipo de defeitos observados na madeira. Graduadores humanos, que classificam madeira, possuem uma taxa de acerto em torno de $48 \%$. Isso indica um baixo índice de acertos no processo não automatizado. Processos automatizados procuram aumentar esse nível de acertos, para que a caracterização qualitativa da madeira seja mais confiável e, consequentemente, haja um ganho no valor agregado das madeiras com alto grau de qualidade (KLINE, et al. 2003).

Apesar do grande avanço nas tecnologias desenvolvidas para a análise visual da madeira, ainda existem dificuldades encontradas nesse processo. Os principais desafios encontrados no processo de análise visual de madeiras estão na identificação e diferenciação dos vários tipos de defeitos da madeira, principalmente os tipos de nós, medula e bolsas de resina. Para que seja possível aumentar o grau de confiabilidade na determinação desses vários tipos de defeito é imprescindível que haja um detalhamento e um melhor entendimento de suas características de origem e desenvolvimento.

Este trabalho busca trazer contribuições para o avanço tecnológico do setor madeireiro no Brasil, fornecendo uma base consistente de imagens de tábuas de Pinus com grande qualidade e informações associadas (da madeira em si, dos defeitos da amostra e da classificação segundo normas da ABNT) para pesquisas que envolvam a análise desse tipo de madeira, abrindo a possibilidade para novos estudos tecnológicos. Por sua oportunidade traz benefícios imediatos a projetos de sistemas de classificação automática de madeira serrada, já que tem como referência uma base de dados de imagens digitais de madeira serrada já classificada, confiável e disponível pode contribuir significativamente no treinamento e aprendizado desses sistemas. Outro aspecto que motiva o seu desenvolvimento é a carência da indústria de madeira serrada no Brasil por tecnologias que permitam agregar valor aos produtos produzidos. $\mathrm{O}$ fato das principais tecnologias disponíveis para o setor serem importadas, aliadas a uma série de dificuldades envolvendo a aquisição de novas tecnologias produtivas, acaba por inviabilizar a adoção de processos automatizados na indústria, devido aos altos custos de aquisição de equipamentos e tecnologias. O trabalho baseia-se na definição e construção de uma base de 
imagens em alta definição de tábuas de madeira serrada de Pinus para uso geral. Associada a cada imagem constam dados referentes à árvore que gerou a amostra, aos defeitos constantes na imagem da tábua e à classificação da mesma quanto sua qualidade. Essa base se beneficia de um sistema computacional para permitir a ampla distribuição e acesso às imagens. Com isso, espera-se que este projeto apóie e incentive a integração entre as áreas de conhecimento voltadas ao setor madeireiro e à computação.

Os estudos tecnológicos envolvidos no desenvolvimento desse projeto contribuem, ainda, para o enriquecimento da base de conhecimento tecnológico local, regional e nacional, dado que a base de dados será disponibilizada a comunidade como um todo, via internet.

O objetivo desse trabalho é a definição e construção de uma base pública de imagens digitais de tábuas de madeira serrada de coníferas, analisando as características de defeitos da madeira, usando um sistema computacional para permitir a ampla distribuição e acesso das imagens, de forma a controlar inserção, distribuição e acesso a essa base.

O projeto tem ainda os seguintes objetivos específicos:

1. Caracterização e separação das imagens adquiridas em conjuntos que representem a tábua serrada e também blocos de imagens das regiões com apresentação de defeitos;

2. Definição da estrutura de metadados e implementação de um banco de dados multimídia para armazenamento das imagens digitais adquiridas e os blocos de imagens que representam seus respectivos defeitos;

3. Desenvolvimento de um sistema computacional de plataforma web para administrar o banco de imagens, possibilitando o armazenamento, consulta e acesso ao conjunto de imagens armazenadas; 


\section{REVISÃO DE LITERATURA}

\subsection{Madeira serrada no Brasil}

A terminologia madeira serrada é aplicada a todos os produtos resultantes do desdobro de uma tora de madeira. Esse processo de desdobro gera vários produtos, sendo os principais: pranchas, blocos, tábuas, dormentes, madeira aplainada, madeira beneficiada, semielaboradas, os perfis e as vigas. As dimensões da madeira serrada proveniente do desdobro de coníferas devem seguir as especificações determinadas na norma NBR 12.498, conforme apresentado na Tabela 1.

Outros produtos, obtidos do reprocessamento da madeira serrada de reflorestamento (Pinus e Eucalipto) com o objetivo de agregar valor ao produto primário, como portas, molduras, painel colado lateral e pisos de madeira, são conhecidos e designados como produtos de maior valor agregado - PMVA (ABIMCI, 2008).

No Brasil, a madeira serrada representa um importante fator econômico. Em 2012, foram produzidos aproximadamente 9,2 milhões de metros cúbicos de madeira serrada de Pinus, sendo que, desses, 90\% foram destinados ao consumo doméstico. Há projeções de um crescimento anual de aproximadamente $1 \%$ na produção e 2,7\% no consumo interno da madeira serrada de Pinus (ABRAF, 2013). 
Tabela 1- Dimensões padronizadas de madeira serrada de coníferas de reflorestamento

\begin{tabular}{lcc}
\hline Tipo de peça & $\begin{array}{l}\text { Espessura Nominal }-\mathbf{e} \\
(\mathbf{m m})\end{array}$ & Largura Nominal $-\ell(\mathbf{m m})$ \\
\hline Caibro & $50 \leq \mathrm{e} \leq 100$ & $50 \leq \ell \leq 100$ \\
Pontalete & $\mathrm{e}=75$ & $\ell=75$ \\
Prancha ou Pranchão & $\mathrm{e} \geq 50$ & $\ell>150$ \\
Pranchinha & $\mathrm{e}=38$ & $\iota \geq 100$ \\
Quadradinho & $\mathrm{e}=25$ & $\iota=25$ \\
Ripa & $\mathrm{e}<25$ & $\ell<100$ \\
Sarrafo & $25 \leq \mathrm{e}<50$ & $25 \leq \ell<100$ \\
Tábua & $25 \leq \mathrm{e}<38$ & $\ell \geq 100$ \\
\hline & & Fonte: NBR $12498(1991)$.
\end{tabular}

\subsection{A madeira de Pinus e as espécies Pinus taeda L. e Pinus elliottii}

Segundo Berni et al. (1979), o gênero Pinus é composto por uma gama de, aproximadamente, cem espécies e é oriundo de regiões temperadas e tropicais. No Brasil, a espécie de Pinus mais usada é a Pinus taeda L., espécie que é aplicada na produção de madeira serrada para: molduras, embalagens, estruturas, móveis e chapas de diversos tipos (SHIMIZU, 2004). As plantações de Pinus taeda L. respondem por cerca de 1,56 milhões de hectares plantados de Pinus em 2012, o que corresponde a $22 \%$ da área plantada do país (ABRAF, 2013).

O Pinus elliottii é uma espécie nativa do sudeste dos Estados Unidos da América e é amplamente cultivada no Brasil, em regiões de clima subtropicais. É uma conífera pertencente à família Pinaceae de gimnosperma, que é caracterizada por produzir resina. A produção natural de oleoresina (mistura complexa de mono, sesqui e diterpenos), pelas espécies de coníferas, é uma autodefesa contra insetos e microrganismos patogênicos. Essa espécie também é muito cultivada na China e Índia. Suas principais aplicações comerciais no Brasil são a destinação da madeira serrada à indústria moveleira, a produção de resina e a extração de oleoresina, devido a seus derivados voláteis, breu e terebintina, por encontrarem muitas aplicações nas indústrias farmacêuticas e químicas. A extração de resina de árvores de Pinus elliottii possibilitou, no Brasil, o surgimento de uma atividade econômica importante no setor florestal que é a produção, processamento e exportação de resina (KRONKA et al., 2005). 
As regiões onde são cultivadas as plantações de Pinus no Brasil são ilustradas na Figura 1 e a evolução da área plantada, de 2005 até 2010, é ilustrada na Figura 2.

A Figura 3 mostra uma relação das principais espécies de Pinus plantadas no Brasil e a quantidade de cada uma no montante de área plantada dessa espécie.

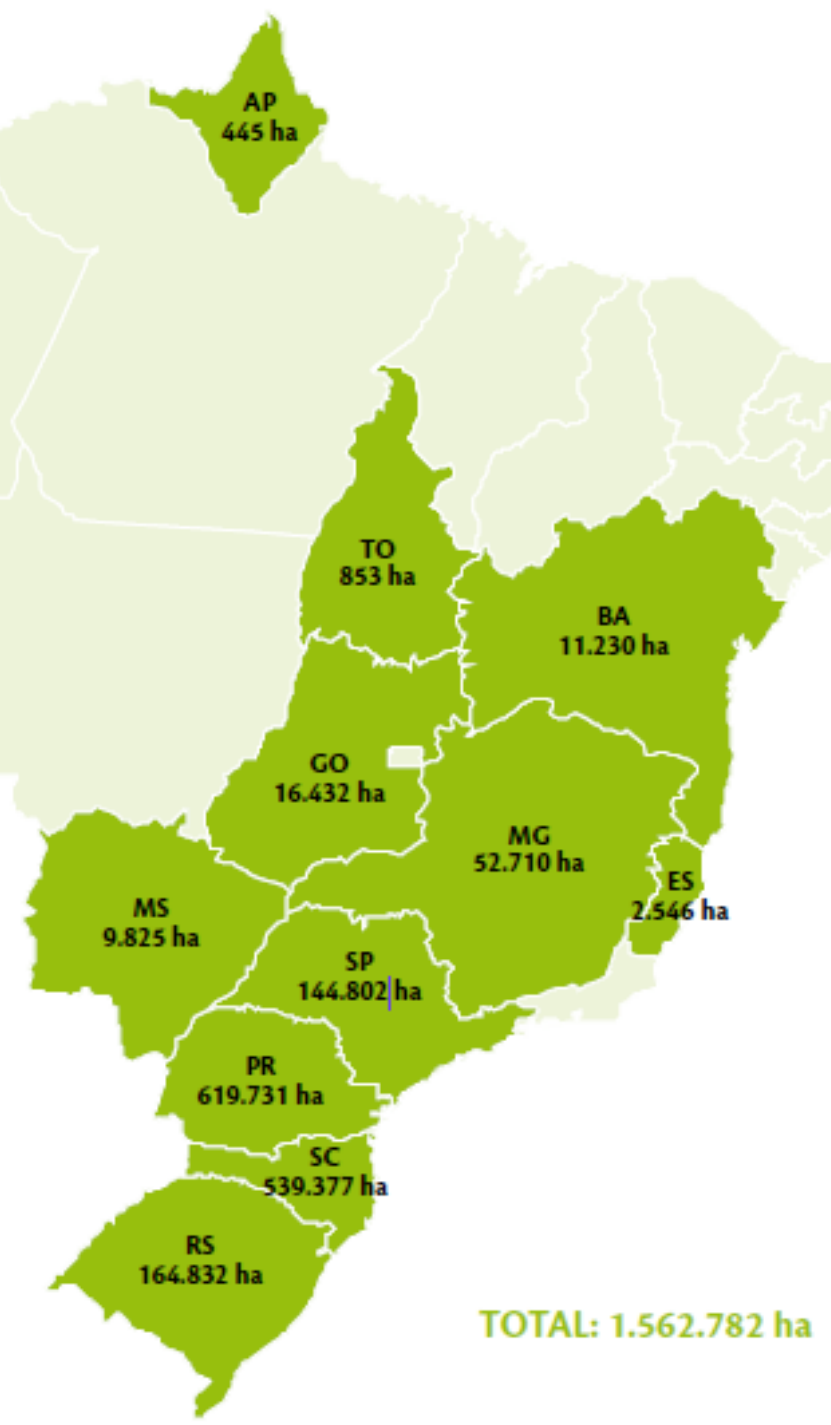

Figura 1 - Localização e áreas das plantações de Pinus no Brasil. 


\section{PINUS}

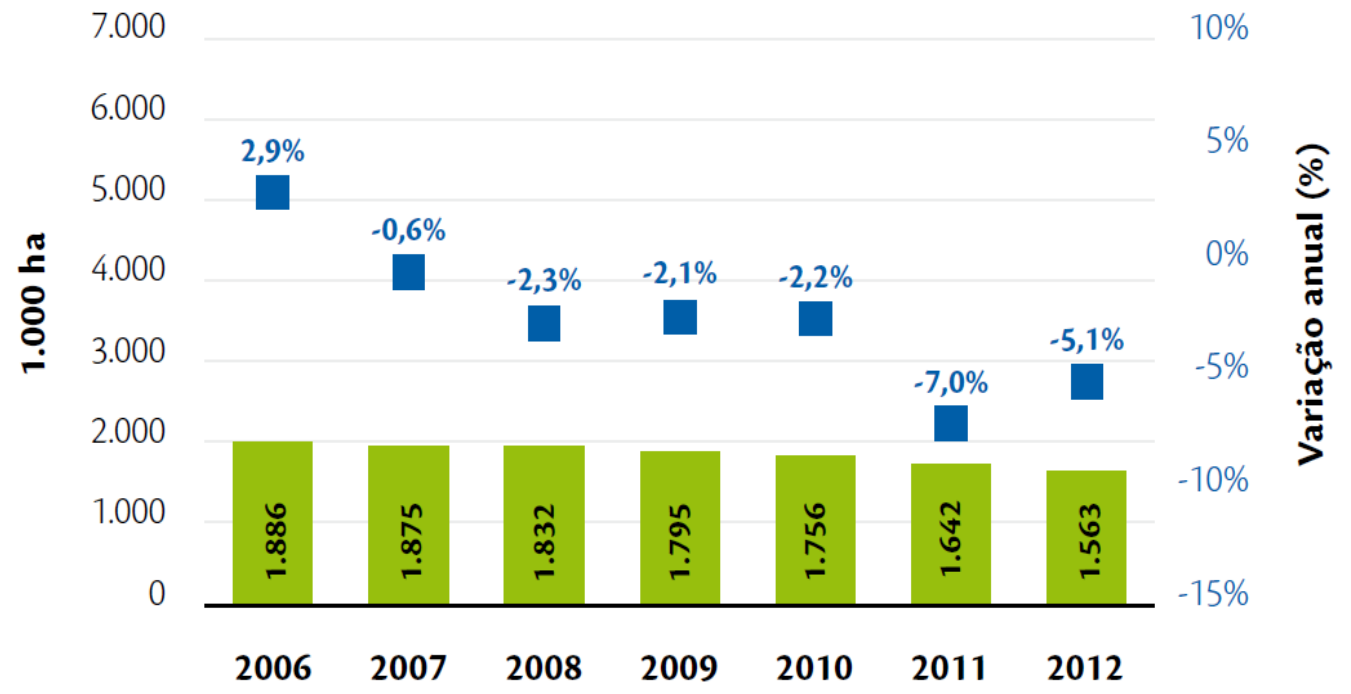

Figura 2 - Evolução da área plantada com Pinus.

Fonte: ABRAF, 2013

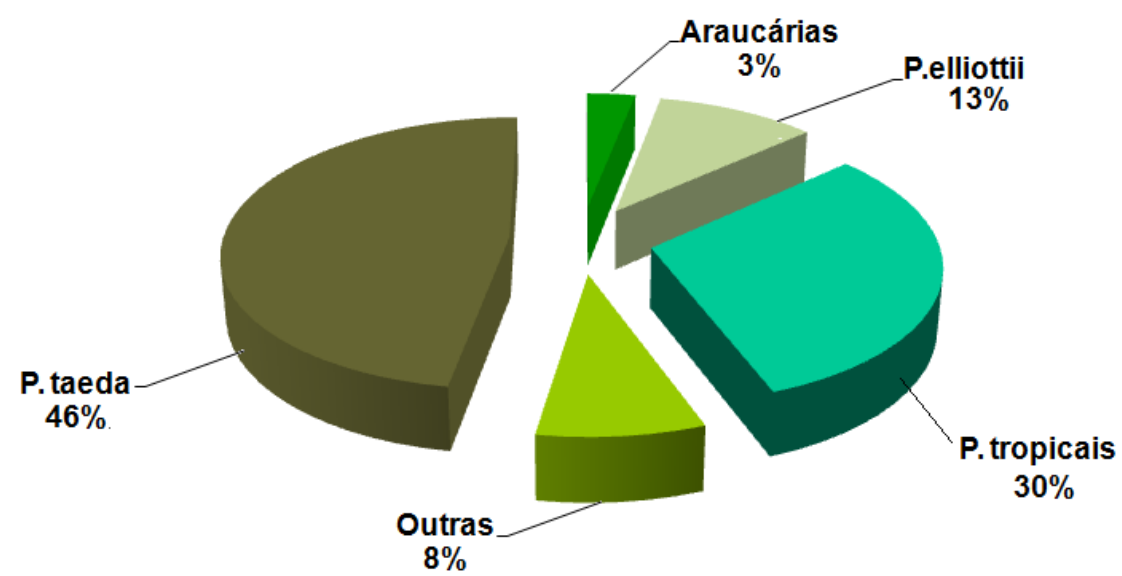

Figura 3 - Principais espécies de Pinus plantadas no Brasil.

Fonte: STPC, 2008

\subsection{Classificação de tábuas de madeira e defeitos}

A classificação de tábuas de madeira serrada é feita através da medição e quantificação dos defeitos apresentados nas duas faces da amostra de madeira serrada considerando-se, para efeitos finais, a face mais prejudicada. $\mathrm{O}$ estudo efetivo dos 
defeitos e a classificação das tábuas são baseados em conceitos e definições amplamente difundidas. A Associação Brasileira de Normas Técnicas (ABNT) disponibiliza normas que preconizam as práticas para a quantificação e classificação de madeira serrada de coníferas no Brasil. A norma NBR-12297 (ABNT, 1991a) fixa as condições exigíveis para a medição de defeitos em madeira serrada de coníferas provenientes de reflorestamento, para uso geral. A referida norma elenca os seguintes defeitos: nós, bolsas de resina, empenamentos, esmoado, furos de insetos inativos, rachas, medição e quantificação da medula, desbitolamento e fendilhado, medição e quantificação da grã.

O nó é o defeito mais comumente encontrado nas tábuas sendo, portanto, um defeito importante ao se classificar madeiras de coníferas. Segundo a norma NBR-12297 (ABNT, 1991a), são destacados vários tipos de nós: nó de face, nó de quina, nó de gravata, grupo de nós, feixe de nós, nó firme, nó cariado, nó solto e nó vazado. As Figuras $4 \mathrm{a}$ e $4 \mathrm{~b}$ ilustram o defeito caracterizado como nó firme e nó solto em tábuas de madeira serradas de coníferas, respectivamente.
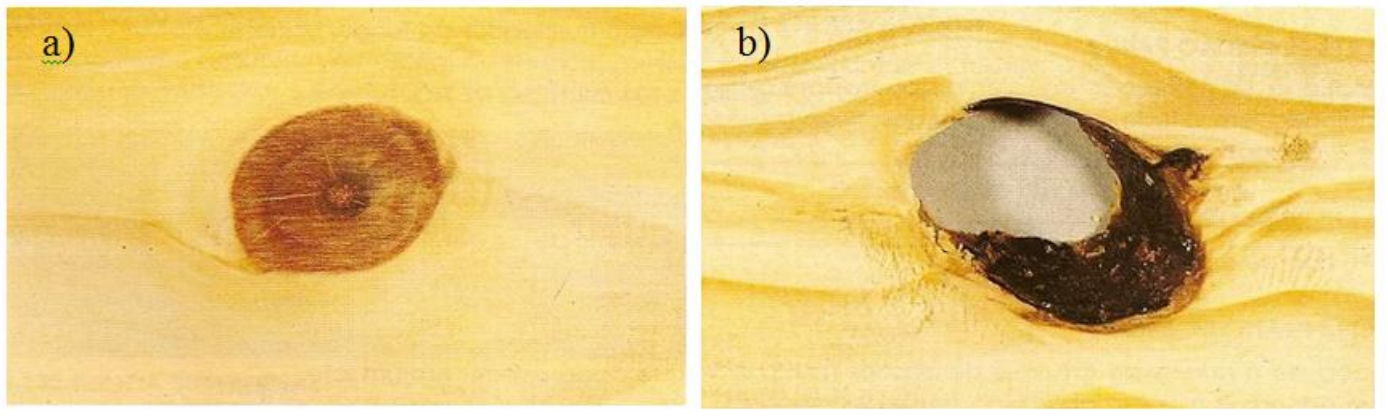

Figura 4 - a) Defeito caracterizado como nó firme; b) Defeito caracterizado como nó vazado.

Fonte: ABPM, 2001

As Figuras 5 e 6 ilustram os defeitos caracterizados como bolsa de resina e medula, encontrados em tábuas de madeira serradas de coníferas. Ilustrações dos demais defeitos podem ser encontradas na norma NBR-12297 e imagens nos catálogos da ABPM (2001). 


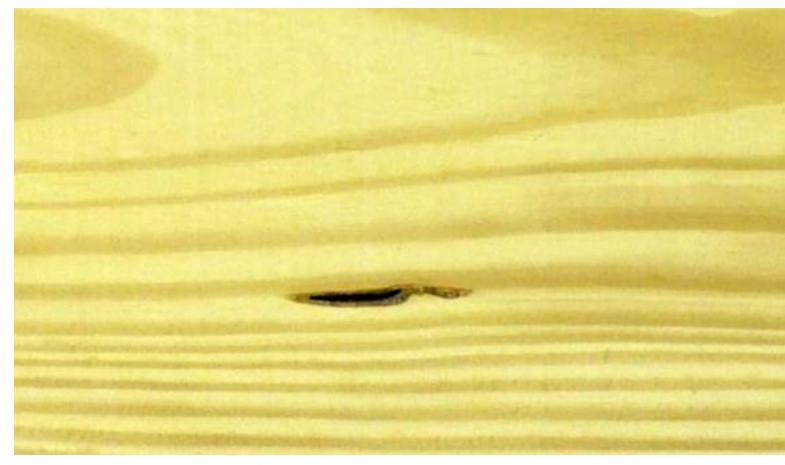

Figura 5 - Defeito caracterizado como bolsa de resina.

Fonte: ABPM (2001)

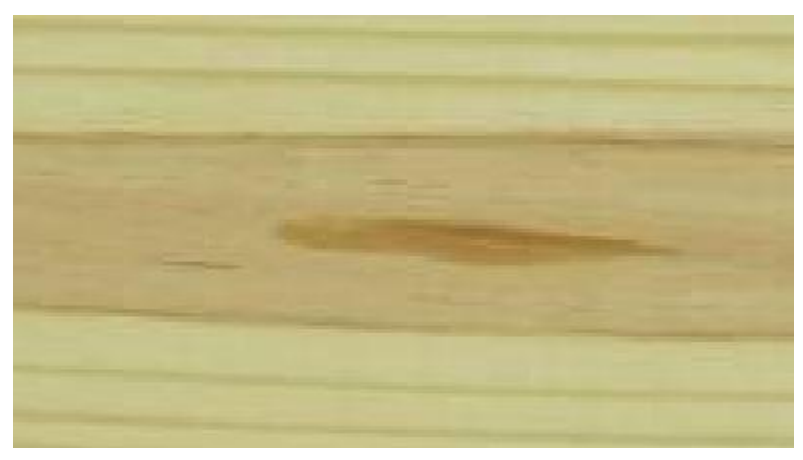

Figura 6 - Defeito caracterizado como medula. Fonte: Rall (2010)

No que se refere à classificação de madeiras serradas de coníferas provenientes de reflorestamento, a norma brasileira NBR-11700 (ABNT, 1991b) norteia esse procedimento, definindo as classes e estabelecendo as condições e as metodologias a serem adotadas. Determina como critérios para a classificação da madeira: o número de defeitos encontrados na madeira serrada, o tipo de defeito e sua importância, além de estabelecer os limites em porcentagem que o defeito pode ocupar da área total da tábua. Com isso, por esse código normativo, as madeiras serradas podem ser classificadas quanto à sua qualidade, em: super, extra, primeira classe, segunda classe e terceira classe. As Figuras 7 e 8 mostram exemplos de imagens de tábuas que seriam classificadas, segundo essa norma, como Super (Figura 7) e Terceira classe (Figura 8). As figuras também evidenciam que, apesar das madeiras apresentarem o mesmo tipo de defeito nó, o tipo desse defeito nó firme ou nó solto, condiciona a classe da tábua, podendo variar de Super, classe mais elevada, para terceira classe, pior classe. 


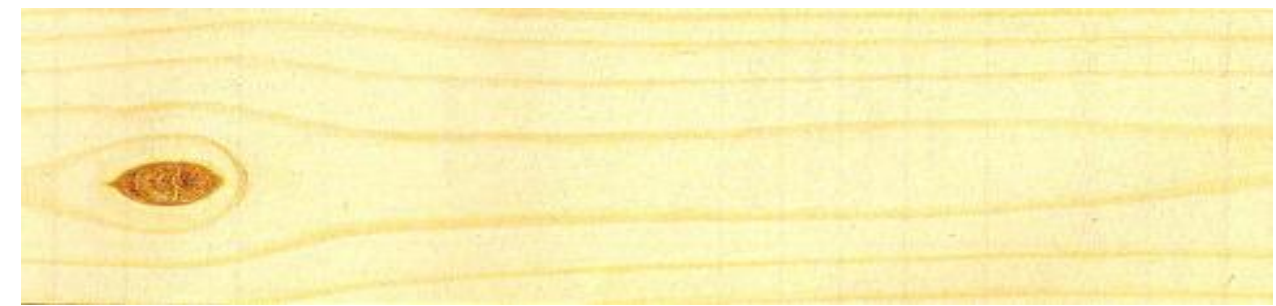

Figura 7 - Presença de nó firme em tábua de classe Super

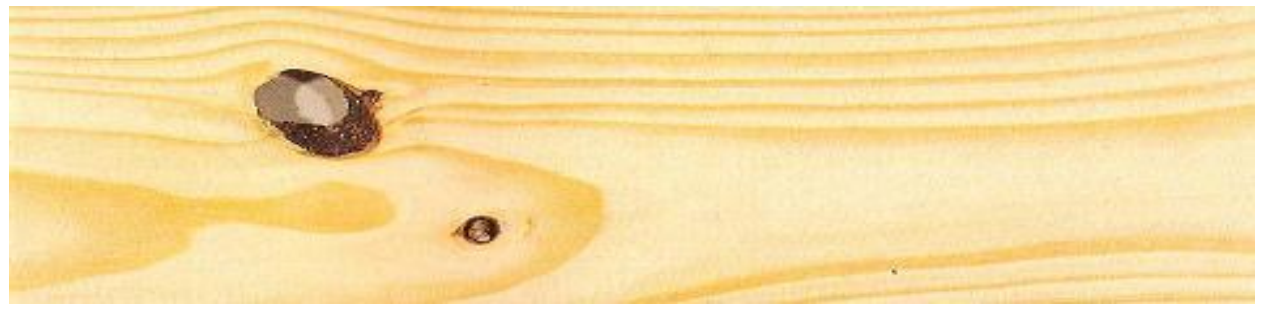

Figura 8 - Presença de nó vazado em tábua de Terceira classe

A Tabela 2 apresenta uma síntese dos defeitos e das cinco classes de madeira serrada estabelecidas pelo código normativo. 
Tabela 2 - Classificação de madeira serrada de coníferas provenientes de reflorestamento. Compilado por Rall (2010), a partir da norma NBR 11700.

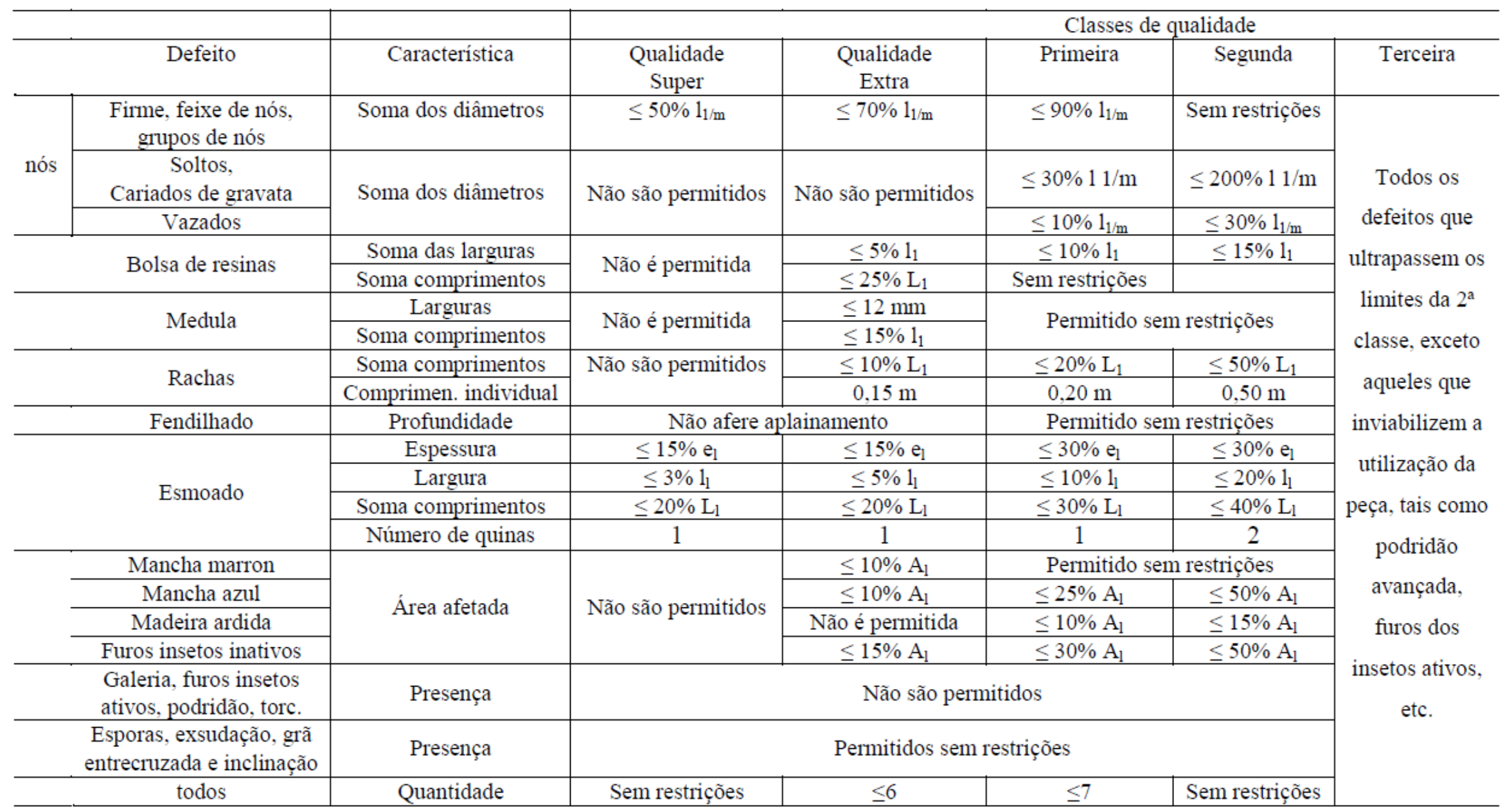

Legendas e abreviações: $\mathrm{L}_{1}$ : comprimento real da peça; $\mathrm{l}_{1}$ : largura real da peça; $\mathrm{e}_{1}$ : espessura real da peça; $\mathrm{A}_{1}$ : área da face classificada da peça; comprimen. comprimento; torc.: torcimento. 


\subsection{Imagem e fotografia digital}

A imagem digital é basicamente um arquivo que guarda os valores de uma função $f(x, y)$, onde esses valores representam a intensidade luminosa no ponto da coordenada $(x, y)$. Esse modelo matemático é necessário para que o computador consiga interpretar e manipular esse arquivo como sendo uma imagem. $\mathrm{O}$ valor dessa função representa o brilho num ponto dado pelas coordenadas espaciais, uma matriz é formada pelo conjunto desses pontos, onde os índices de linha e coluna são as coordenadas $(x, y)$. Esse ponto é o menor elemento da imagem e é chamado de pixel, que é abreviação de picture-element ou elemento da figura, menos comum, mas também usado em algumas literaturas, é o termo pels (GONZALEZ; WOODS, 2000).

A imagem digital é gerada através de um sensor eletrônico que equipa as câmeras fotográficas digitais, conhecidos como Charge-coupled device (CCD), que são responsáveis por converter sinais luminosos em sinais elétricos, os quais são tratados posteriormente por um conversor analógico-digital que associa as tensões elétricas a valores numéricos entre 0 e 255, sendo 0 a tensão mínima e 255 a tensão máxima. Esses valores numéricos são utilizados também para associar as cores do modelo de cor RGB aplicado nas imagens digitais, onde R é vermelho (red) e é associado ao valor $234, \mathrm{G}$ é verde (green) associado ao valor 123 e $\mathrm{B}$ o azul (blue) associado ao 052, sendo que quanto maior esse valor mais intensa é a cor. Neste modelo de cor, RGB, a imagem é formada pela sobreposição de três planos independentes, um para cada espectro de cor primária (verde, vermelho e azul), onde sua combinação produz imagens de cores compostas (TRIGO, 2005). Outro componente da imagem, além da cor, é a iluminância que, segundo Trigo (2005), é a luz de maior importância para aquisição de uma imagem por meio de fotografia e pode ser aferida por um luximetro.

$\mathrm{Na}$ composição das imagens digitais, a Equação 1 avalia a iluminância de uma cor no modelo RGB.

$$
\mathrm{I}=0.299 \mathrm{R}+0.587 \mathrm{G}+0.114 \mathrm{~B}
$$

Essa equação é aplicada na conversão de imagens coloridas, que implementam o modelo RGB, em imagens que são apresentadas em tons de cinza (GOMES; VELHO,1998).

A qualidade visual da imagem se dá através do que se conhece como resolução da imagem, que inclusive determina a capacidade de gerar imagens de 
uma câmera digital e também seu valor de mercado, sendo que, quanto maior a resolução de uma imagem gerada por uma câmera fotográfica digital maior o seu valor de mercado.

A resolução é o produto do número de pixels gerado na vertical pelo número de pixels gerados na horizontal, sendo, tecnicamente, chamada de resolução espacial, que representa o número de pixels que formam a imagem digital e define a qualidade da mesma. Esse número de pixels que uma câmera digital pode gerar é definido pelo tipo e qualidade do sensor instalado no equipamento fotográfico. Uma imagem digital captada com qualidade considerável pode gerar imagens formadas por milhares de pixels, sendo assim utiliza-se um prefixo para determinar a resolução espacial dessa imagem, ou equipamento, e facilitar a leitura. Adota-se o prefixo "mega" representando milhões de pixels, a Tabela 3 apresenta uma relação das resoluções espaciais mais usadas (TRIGO, 2005).

\begin{tabular}{ccc}
\multicolumn{3}{c}{ Tabela 3 - Resolução espacial de imagens digitais } \\
\hline \multicolumn{2}{c}{ Quantidade de pixels } & Resolução \\
Na Horizontal & Na Vertical & \\
\hline 640 & 480 & 0,3 megapixel \\
800 & 600 & 0,5 megapixel \\
1024 & 768 & 0,8 megapixel \\
1280 & 1024 & 1,3 megapixels \\
1600 & 1200 & 1,9 megapixels \\
2240 & 1680 & 3,8 megapixels \\
3072 & 2048 & 6,3 megapixels
\end{tabular}

Outra característica da imagem, que também é determinada pelo sensor eletrônico que equipa a câmera digital utilizada na aquisição da imagem, é a profundidade da cor, que segundo Gonzalez e Woods (2000), representa o número de cores aplicadas na geração de cada pixel que forma a imagem.

A profundidade da cor é expressa em números binários, onde cada bit associa no máximo dois tons, sendo cada tom associado ao estado do bit. A profundidade é determinada pela relação $2^{n}$, sendo " $n$ " a profundidade da cor. Por exemplo, um sensor capaz de trabalhar com 2 bits geraria imagens de $2^{2}$ tons, ou seja 4 tons de determinada cor.

A qualidade da imagem, ou resolução espacial, varia de acordo com a quantidade de pixels com a qual a imagem foi capturada. Quanto maior esse valor maior o tamanho em bytes (unidade de medida de capacidade de armazenamento de mídia 
e tamanho de arquivos de computador) do arquivo de computador gerado pelo equipamento fotográfico. Esse arquivo segue uma codificação que pode variar de acordo com as especificações de cada tipo de arquivo e sistema de armazenamento. Cada codificação se adéqua a aplicações específicas, sendo que os mais utilizados e conhecidos são JPEG - Join Photographics Experts Group, que gera extensão JPG no nome do arquivo de imagem; TIFF - Tagged Image File Format, o qual gera a extensão TIF no nome do arquivo de imagem; GIF - Graphics Interchange Format e BMP - Bitmap (TRIGO, 2005).

\subsection{Plataforma web}

A World Wide Web (WWW), ou simplesmente web, teve seu projeto inicial em 1989 e foi consolidada como ambiente gráfico para internet no consórcio firmado em 1994 com objetivo de desenvolver padrões e incentivar participação entre os diferentes sites da Internet (TITTEL, 2002).

A WWW permite que os usuários acessem e visualizem conteúdos multimídia na Internet, ou seja, documentos com texto, vídeos, gráficos, imagens e sons, sobre os mais variados assuntos. A internet foi criada para ser utilizada por universidades americanas no início dos anos 70; já a web, conforme já afirmando, é um pouco mais recente, surgiu no início dos anos 90 (DEITEL, 2001).

O termo "plataforma web" surgiu devido ao fato de que os softwares e sistemas de informação passaram a ser, cada vez mais, desenvolvidos para funcionarem sobre as regras e metodologias do ambiente da internet criadas para a WWW. Nesta plataforma os usuários, a partir de um navegador, podem acessar um imenso conteúdo armazenado em servidores espalhados pelo mundo. Originalmente a web era baseada em textos e links para acessá-los, hoje, com o aumento da diversidade de conteúdos e tipos de dados, são disponibilizados todo tipo de informação e formato de arquivos, sendo que o conceito de links passou a ser de chamado de hipermídia (TITTEL, 2002).

Para Zaneti (2003), a web foi originalmente concebida para disponibilizar e divulgar o conhecimento científico, porem também tem sido utilizada como meio de acesso e comunicação a vários tipos de sistemas de informação empresariais. O que acarreta em uma variedade de oportunidades de negócio para as organizações. Segundo ele os sistemas de informação baseados na web possuem 
características específicas, que permitem supor que para desenvolver esse tipo de sistema existam diferenças em relação a sistemas convencionais, não web.

\subsection{Modelagem e documentação de banco de dados}

Segundo Date (2004), um banco de dados é um conjunto de dados organizados, relacionados entre si e referentes a algum contexto organizacional. O projeto de um banco de dados deve seguir algumas regras de construção, conhecidas como modelagem do banco de dados. A modelagem do banco de dados pode ser comparada à documentação do projeto de construção de uma casa, que inclui sua planta, seu projeto elétrico e hidráulico, paisagismo, entre outros. O banco de dados não é somente o conjunto de arquivos de computador armazenados em disco; ele consiste, também, de documentos que descrevem esses arquivos e que são associados a eles, além de um sistema de gerenciamento de banco de dados, o SGBD. Segundo o autor, os documentos mais importantes da modelagem são:

- Modelo conceitual do banco de dados: o modelo conceitual de um banco de dados é um documento apresentado em forma de diagrama, onde são representados graficamente os componentes do banco de dados, ou seja, suas entidades que representam a abstração do mundo real. Por exemplo, no contexto do presente trabalho uma árvore se transforma em uma tabela dos dados que representam essa árvore, sendo "árvore" uma entidade do banco de dados. O modelo gerado nesta etapa apresenta de forma gráfica e relativamente simples, o conceito do banco de dados, que o objetivo do mesmo pretende atingir.

- Modelo lógico e diagrama de entidade e relacionamento: o modelo lógico, juntamente com sua representação gráfica designada diagrama entidade e relacionamento (DER), de um banco de dados é um documento construído em forma de diagrama, onde são representados graficamente os componentes do banco de dados, ou seja, suas entidades que representam a abstração do mundo real, o relacionamento e a dependência funcional entre essas entidades. Além de representar os campos que compõem as tabelas (entidades) do banco de dados. Esse é um documento mais técnico que o modelo conceitual e, para seu entendimento, é necessário um conhecimento prévio sobre a teoria de banco de dados. O resultado da aplicação dos conceitos delineados na metodologia do modelo entidade e relacionamento é a geração 
de um documento conhecido, na arquitetura de banco de dados, como Diagrama Entidade Relacionamento, ou simplesmente DER.

- Modelo físico: esse modelo é um documento em forma de texto que representa a construção do banco de dados propriamente dito, ou seja, a geração dos arquivos de computador que compõem o banco de dados. Para que esses arquivos sejam criados é necessária a edição e execução de uma série de comandos, em linguagem de programação e consulta para banco de dados (SQL), a partir da interface de um Sistema de Gerenciamento de Banco de Dados (SGBD), que interpreta tais comandos e os executa criando assim as estruturas lógicas e binárias necessárias para receber os dados e mantê-los armazenados, organizados e com todas as características pertinentes a um banco de dados consistente (DATE, 2004). A esse conjunto de comandos é dado o nome de Modelo físico do banco de dados, sendo que esse conjunto de comandos se executado novamente em qualquer SGBD compatível com o que ele foi criado, gera um banco de dados exatamente igual ao original. Ao inserir e executar comandos em linguagem SQL (utilizada pelo MySQL) para serem executados no SGBD, os mesmos vão sendo armazenados em um histórico configurado no próprio SGBD. Esse histórico é gravado em forma de arquivo texto com os comandos executados em sua sequência original e pode ser recuperado e impresso. Esse texto é o Modelo Físico do banco de dados.

- Dicionário de dados: consiste em uma planilha que descreve a estrutura das tabelas (relações de dados) no que se refere aos seus campos (atributos). Essa planilha contém, geralmente, as colunas do nome do campo, o tipo de dados que o campo recebe, suas restrições que são as determinações das regras de negócio impostas ao modelo de dados tais como campo obrigatório e campo chave (campos que não aceitam dados duplicados e garante a unicidade dos mesmos) e o mais importante, a descrição dos dados, ou seja, que tipo de informação aquele determinado campo ira receber e armazenar, assim, em situações futuras, se pode entender exatamente como recriar o banco de dados e para que foram criados cada campo.

\subsection{Banco de dados na web}

O uso de bases de dados na web tem crescido muito, independente do tipo de coleção de dados. Hospedar bancos de dados em servidores que disponibilizam 
seu conteúdo através de páginas para consulta, manipulação e download, é um procedimento cada vez mais comum. Não importa se a empresa é de grande ou pequeno porte, se a natureza do negócio é estatal, educacional ou pessoal, se tem fins lucrativos ou não, disseminar e reunir informações na web é universal. Um banco de dados, por si só, não pode ser apresentado na web, ele depende de uma aplicação, como um site com funcionalidades, por exemplo, a qual é responsável pela busca, seleção, exibição, alteração e exclusão dos dados através de ferramentas implementadas no aplicativo, que sejam capazes de receber e aplicar critérios de consulta a esses dados (BUYENS, 2001).

\subsection{Banco de dados multimídia}

O termo multimídia é usado para definir a combinação dos diferentes tipos de mídia existentes. Esse termo é utilizado e associado a inúmeras tecnologias. Uma apresentação de slides didática, por exemplo, é um tipo de multimídia quando a mesma faz uso de textos, imagens, áudio, vídeo e gráficos, que são os diversos tipos de mídia existentes. Apesar de textos, imagens e áudio serem considerados tipos de mídia, enquanto os vídeos e animações serem exemplos de multimídia, por serem compostos por mais de um tipo de mídia, o senso comum assume que as imagens também são classificadas como dados multimídia, por não serem tratados como os textos nos meios digitais (JAIMES et al., 2005).

Um Sistema de Gerenciamento de Banco de Dados (SGBD) é um conjunto de programas que tem por função gerenciar coleções de dados e garantir as seguintes propriedades: desacoplamento das aplicações, consistência, persistência, interface, acesso multiusuário e recuperação em caso de falha. Os SGBDs comuns lidam com dados textuais, não interpretados, tendo certas limitações para trabalhar com dados contínuos como imagens, áudio, vídeo e animações (DATE, 2004).

Para gerenciar dados contínuos, conhecidos como dados multimídia (imagem, áudio, vídeo e animações), o SGBD deve ter capacidades distintas e recursos específicos para esse fim. Dados multimídia como imagens e vídeos, por exemplo, tem algumas características que os dados comuns como textos não apresentam, sendo a mais relevante delas o fator tempo. Para gerenciar um banco de dados com dados multimídia e prover recursos de interpretação de conteúdo desses dados existem SGBDs específicos conhecidos como Sistemas de Gerenciamento de Dados Multimídia (SGBDM ou 
MSGBD), apesar de que os SGBDs mais conhecidos no mercado implementam ferramentas e características para dados multimídia sem modificarem sua nomenclatura comercial. Um dos princípios fundamentais dos SGBDs é a garantia da integridade e consistência dos dados durante a pesquisa e recuperação, quando se trata de dados multimídia isso se torna mais importante ainda já que tais dados são formados utilizandose muitos bytes, muitas vezes chegando a gigabytes (FRANÇA, 2012). Ainda, segundo França (2012), existem diferentes mecanismos de armazenamento desse tipo de dados, entre eles são ressaltados dois tipos mais utilizados por SGBDs comuns, são eles:

- Referência externa, que consiste em manter no banco de dados apenas a referência ao arquivo que se deseja buscar, sendo esse arquivo (uma imagem por exemplo) armazenado fora do banco de dados. Esse tipo de mecanismo tem como desvantagem o fato de que, devido ao arquivo estar armazenado fora do banco de dados, o SGBD não consegue garantir a consistência e integridade do dado.

- Armazenamento de dados multimídia não interpretado, esse mecanismo de armazenamento utiliza um tipo de campos do SGBD desenvolvido para objetos multimídia, que são chamados de campo BLOB (binary long object). Esse campo recebe os dados multimídia e os armazena diretamente no banco de dados, mantendo assim sua integridade e consistência. A desvantagem desse tipo de armazenamento é que o objeto não é recuperado pouco a pouco, ele deve ser lido por completo para então ser apresentado, o que pode levar muito tempo, já que os dados multimídia podem resultar em arquivos de tamanho elevado. Um vídeo de alguns minutos de duração com alta resolução de imagem e som chega facilmente a um gigabyte (1 GB).

\subsection{SQL - Linguagem de consulta estruturada}

A SQL (Structured Query Language), ou linguagem de consulta estruturada, é a linguagem padrão para acessar sistemas de gerenciamento de banco de dados relacional (RDBMS). Esta linguagem é utilizada para armazenar, manipular e recuperar dados a partir de um banco de dados e para ele (LARMAN, 2005).

Todo sistema de gerenciamento de banco de dados aceita, ou deve aceitar, os comandos SQL, virtualmente, conforme afirma Buyens (2001). As páginas web que usam banco de dados, em sua maioria, constroem suas próprias instruções SQL, incorporando geralmente opções ou valores de busca recebidas do usuário da web pelo 
navegador. Portanto o desenvolvimento de banco de dados web exige um conhecimento, mínimo ao menos, da linguagem SQL.

\subsection{Sistema de gerenciamento de banco de dados MySQL}

Segundo Date (2004), o SGBD - Sistema de Gerenciamento de Banco de Dados mais utilizado em todo o mundo é o MySQL, por ser muito poderoso e ter um custo baixo em relação a seus concorrentes na sua versão comercial, além de disponibilizar uma versão gratuita. Além disso, Buyens (2001) aponta outras características que o tornam mais utilizado: ser gratuito e de código aberto, rápido, confiável e de fácil utilização, possuir compatibilidade com diversas plataformas, tais como Windows, Linux, OS2, entre outras, suportar acesso por aplicações desenvolvidas em diferentes linguagens de programação, entre outras, proporcionando maior controle e flexibilidade ao sistema desenvolvido e se adaptando perfeitamente a aplicações de sistemas distribuídos, com arquitetura aplicação orientada a serviços, por meio de servidores de aplicação web.

Date (2004) afirma que o SGBD MySQL, por ser um banco de dados relacional, armazena os dados em forma de tabelas e relaciona esses dados entre si, estabelecendo ligações entre os diversos componentes do banco de dados através de dependências referenciais entre as tabelas. Tais tabelas, no MySQL, podem conter dados não contínuos (textos), conhecidos como dados tipo objeto. Esse recurso permite o armazenamento de áudio, vídeo e imagens nas tabelas do banco de dados e, por ser relacional, permite a associação desses objetos a seu metadados, que são dados textuais que descrevem dados do tipo objeto.

É o sistema de gerenciamento de banco de dados que provê interface e ferramentas que possibilitam ao desenvolvedor o acesso, manipulação, armazenamento e consultas aos dados armazenados em um banco de dados. O MySQL oferece um gerenciador e um servidor de banco de dados robusto, com tecnologia de controle para múltiplos usuários em acesso concorrente e suporte a aplicações com distribuição de componentes do banco de dados em diversos servidores. Além de oferecer ferramentas poderosas de segurança de dados, que garantem acesso ao banco de dados restrito somente a pessoas autorizadas. Outra característica do MySQL é que ele implementa linguagem SQL, que é a linguagem de banco de dados mais utilizada no mundo tornando-o, assim, um gerenciador de banco de dados compatível com a maioria dos sistemas. O MySQL foi adquirido da empresa Sun Microsystens pela empresa Oracle 
recentemente, a qual deu continuidade em todos os seus trabalhos e versões do programa, mantendo sua distribuição gratuita e atualizando as versões pagas (MYSQL, 2013).

\subsection{Desenvolvimento de programas para plataforma web com JAVA}

\subsubsection{Linguagem de programação Java}

A linguagem de programação Java foi criada como parte de um projeto chamado "Green Project" em 1991, pela empresa americana Sun Microsystens. A princípio se chamava OAK; foi originalmente concebida para ser aplicada no controle de eletrodomésticos como TV, CD players, microcomputadores e etc., como simples ferramenta de programação. Como a linguagem se mostrou mais poderosa do que era a intenção, passou a ser amplamente utilizada (LEITE, 2006).

Segundo Horstmann (2003), a linguagem Java não foi desenvolvida com objetivos acadêmicos, para o aprendizado de lógica matemática e computacional, como a maioria das linguagens de programação, mas para controlar equipamentos eletrônicos. Por este fato ela é relativamente difícil de ser utilizada para escrever programas básicos, porém, após o seu domínio por parte do desenvolvedor, ela demonstrou um alto desempenho para produção sistemas computacionais completos e funcionais, que rodam perfeitamente em qualquer plataforma de software e hardware. A linguagem Java possui muitos conteúdos adicionais, denominadas como bibliotecas de classes, que incluem funcionalidades extras para desenvolver aplicações substancialmente boas. Além disso, como a linguagem Java foi projetada para Internet ela possui dois atributos que a tornam muito adequadas: segurança e portabilidade. Possui muitas características de segurança que garantem que applets (pequenas aplicações Java) "mal intencionadas" não executem em seu computador, sem isso seria sempre perigoso navegar na web. Outra grande vantagem é a portabilidade, um mesmo programa executará em sistemas operacionais diferentes, com pouca ou nenhuma adaptação, como Linux, Windows, Unix ou Macintosh. Isso é possível devido à maquina virtual Java, que é instalada no computador, quando se executa um applet (HORSTMANN, 2003).

\subsubsection{Java Virtual Machine - JVM}

Para que a linguagem de programação Java forneça a seus programas mais portabilidade que outras linguagens de programação de alto nível ela 
implementa uma arquitetura distinta da empregada nas outras linguagens. Na compilação do código fonte dos programas em Java não é gerado um arquivo executável específico para algum sistema operacional, em vez disso é gerado um código chamado de bytecode. $\mathrm{O}$ bytecode é um código de baixo nível de programação, ou seja, mais próximo da linguagem de máquina, porém, não é específico para algum processador e nem faz interface específica com determinado sistema operacional, ele é um código criado para uma camada de software que já esteja instalada. Essa camada funciona como um sistema operacional genérico, deixando transparentes as particularidades do sistema operacional real (MEDINA; FERTIG, 2005).

Essa camada de software é chamada de Java Virtual Machine (JVM), ou máquina virtual Java. A JVM faz a interpretação dos bytecodes para um código executável no sistema operacional em que se encontra instalado. Esse recurso permite que um programa escrito em Java e que seja compilado para bytecode possa ser executado em qualquer máquina que tenha a versão adequada ao sistema operacional da JVM instalada. Durante a execução, esse código será traduzido em tempo real para a linguagem proprietária e executado. A tradução do código em bytecode é feita em tempo real, durante a execução do programa, o que pode ser entendido como uma espécie de interpretação, portanto, não se pode afirmar que a linguagem de programação Java seja puramente interpretada ou compilada. Devido a essa característica, a linguagem Java passa a ser extremamente interessante para o uso na Internet, visto que um código Java que esteja presente em um site pode ser executado em qualquer plataforma que contenha a JVM instalada. Os browsers, normalmente, já contêm uma JVM para que possam trabalhar com sites que contenham programas Java (MEDINA; FERTIG, 2005).

A Figura 9 apresenta as etapas necessárias para a execução de um programa Java.

\subsubsection{Glassfish}

O Glassfish é um servidor de aplicação, gratuito e de código aberto, criado para ser executado sob a máquina virtual Java, sendo empregado no desenvolvimento e execução de aplicações que rodarão na plataforma web, ou seja, programas de computador que são executados em browsers e funcionam como sites na internet, porém com funcionalidades que páginas comuns da internet não possuem. Em sua 
versão 3.1, o Glassfish conta com funcionalidades que possuem características primordiais para servidores que hospedem aplicações de médio e grande porte. Essas características como alta disponibilidade, escalabilidade, tolerância a falhas, interoperabilidade nativa com outros serviços, backup e recuperação, analisador de desempenho, balanceamento de carga, entre outras resultam em aplicações mais estáveis, confiáveis e otimizadas (SOUZA, 2011).

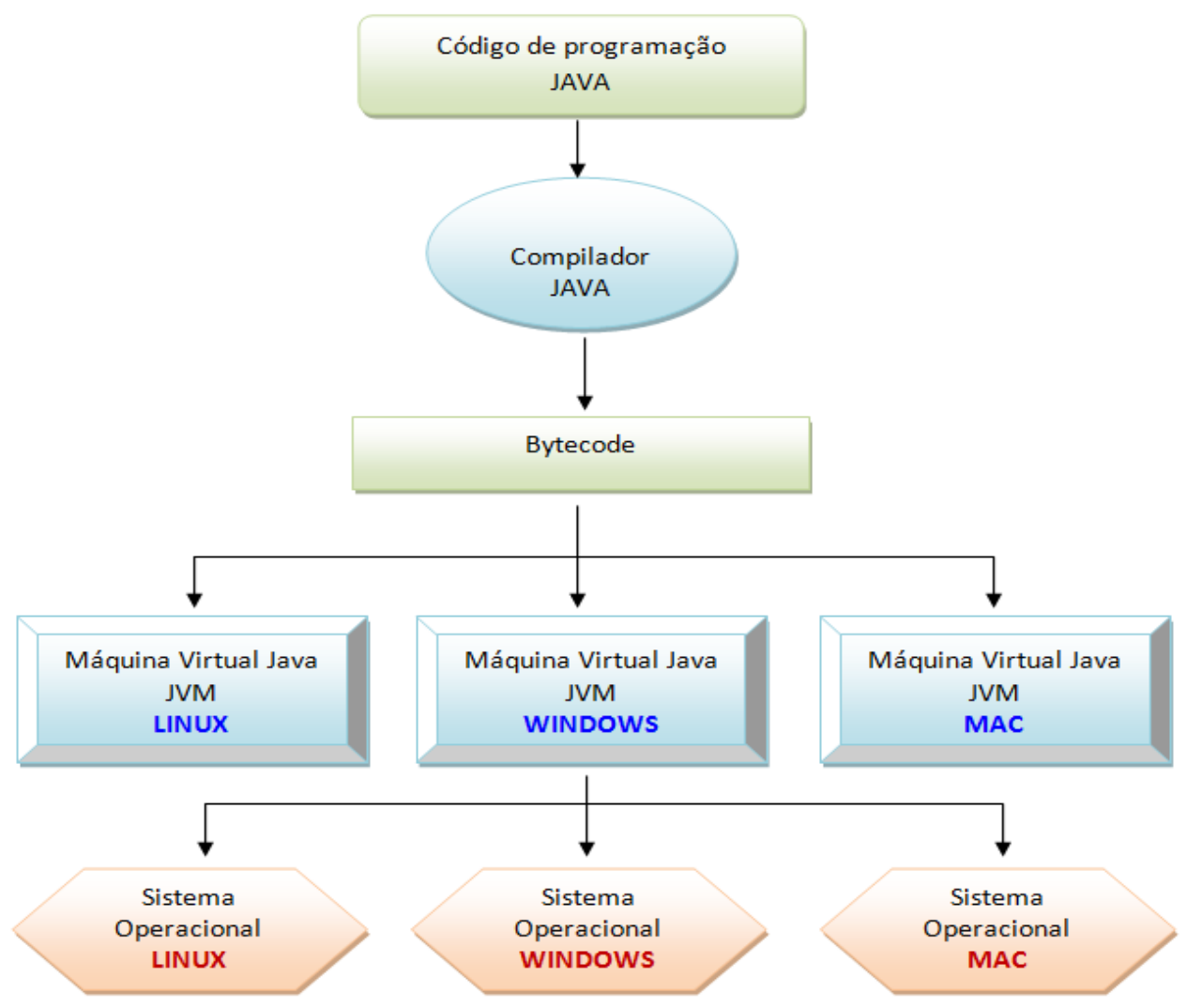

Figura 9 - Etapas para construção e execução de aplicação em linguagem Java.

Servidores de aplicação são programas que fornecem serviços, infraestrutura e ferramentas para o desenvolvedor do software focar seus esforços na implementação da lógica e solução das regras de negócio envolvidas no problema. Sem a utilização de servidores de aplicação o desenvolvedor é obrigado a construir e preparar toda a infraestrutura da aplicação. Esses serviços, fornecidos pelo servidor de aplicação, tem como vantagens e características: diminuir a complexidade do desenvolvimento, controlar o fluxo de dados, gerenciar a segurança e aprimorar o desempenho do programa. Os servidores de aplicações utilizam uma arquitetura distribuída em 3 camadas (cliente, servidor de aplicação e banco de dados). A primeira camada é o front-end, que geralmente 
são browsers, os quais servem para apresentar a aplicação ao usuário, além de fazer algumas validações. A aplicação propriamente dita é considerada a segunda camada, executada no servidor de aplicação e o servidor de banco de dados é a terceira camada (APPLICATION SERVERS, 2003).

A Figura 10 demonstra a arquitetura básica de um servidor de aplicação.

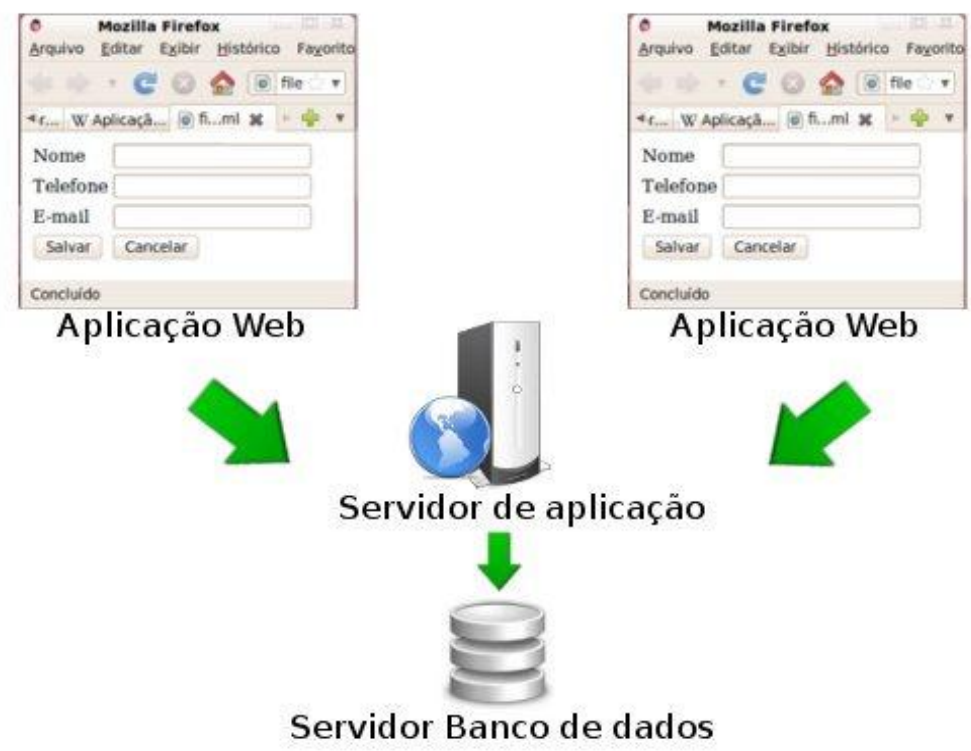

Figura 10 - Arquitetura básica de um servidor de aplicação

Fonte: Souza (2011)

\subsubsection{Plataforma de desenvolvimento de software Netbeans IDE 7.2.1}

O Netbeans é o ambiente de programação mais usado para desenvolvimento de aplicações e serviços web. É um ambiente com muitos recursos e ferramentas que auxiliam o desenvolvedor e agilizam seu trabalho. Tem distribuição gratuita e participa das organizações de softwares livres. O projeto Netbeans partiu de um outro denominado Xelphi, em meados de 1996.Tal projeto despertou interrese por implementar tecnologia Java e deu origem ao surgimento de uma empresa chamada NetBeans. Suas primeiras versões comerciais foram lançadas em 1999. Ainda em meados de 1999 a Sun Microsystems a adquiriu, sendo ainda seu principal patrocinador. No ano de 2000 a Sun lançou sua primeira versão do produto e o vem atualizando desde então. O NetBeans possui interface flexível e customizável, disponibilizando um ambiente 
organizado em janelas com módulos de ferramentas integradas (SEVERO, 2005).

Segundo Severo (2005), ferramentas e plataformas de desenvolvimento são extremamente úteis em grandes projetos de aplicações, produzem ganhos significativos de produtividade. Entre as principais características de uma IDE destacam-se a disponibilidade de um conjunto de ferramentas para auxiliar nas tarefas e a integração em um único ambiente de tudo que é necessário para a construção do software. Recursos como, editor de texto para código fonte, compilador, execução, depuração de erros, editor de propriedades, editor de formulários, tópicos de ajuda, gerenciador, janela de execução, sistema para controle de versões, entre outros.

Os principais recursos da plataforma Netbeans são: interface com o usuário rica em ferramentas, editor de códigos com em recursos visuais, gerenciamento da estrutura do seu projeto localmente ou remotamente, multi-plataforma, ferramentas de gerenciamento de código, depurador e compilador de programas, suporta as linguagens Java, C, C++, suporte à XML e HTML, recursos para desenvolvimento de serviços web, monitoramento de aplicações, indentação automática de código disponível, refatoração básica de código Java, conexão e suporte aos bancos de dados mais utilizados WARKEN (2012).

\subsubsection{Tecnologias de classificação automatizada de madeira serrada}

O processamento de imagens digitais tem sido utilizado na seleção e classificação de diferentes materiais. Vários trabalhos relataram a utilização de softwares comerciais no processamento de imagens digitais podendo-se citar, como exemplos: Spósito (2003), que utilizaram o software SIARCS na avaliação da ação do fungo causador da mancha preta em frutos cítricos, Cruz et al. (2008), com uso do mesmo software emissividade das bandas do verde e do vermelho - na avaliação de coberturas proporcionadas pela semeadura de leguminosas e de gramíneas, Teixeira et al. (2006) na análise de plântulas de milho, que foram submetidas às ferramentas do programa Scilimage e Zabot et al (2008), com o software Sigma Scan Pro v. 5.0, 79 Jandel Scientific na avaliação de plântulas de feijão.

No campo da tecnologia da madeira pode-se citar como trabalho referencial o de Kauppinen (1999), que desenvolveu um classificador para seis tipos de defeitos de tábuas de Pinus, utilizando histogramas - bandas vermelha, verde e azul - e 
obtendo 34\% de erro no processo classificatório. Esse alto índice de erros pode ter ocorrido devido à dificuldade de classificar e diferenciar alguns dos defeitos propostos, como, por exemplo, os nós cariados.

Rall e Ballarin (2007), com o auxílio dos softwares Idrisi e ImageTool, realizaram a segmentação e classificação supervisionada de anéis de crescimento de Pinus Taeda L.

Entretanto, vem sendo relatado o desenvolvimento de vários softwares para a resolução de problemas específicos tanto no campo geral quanto no campo específico da tecnologia da madeira.

Koivo et al. (1989) desenvolveram algoritmo específico para classificar nove classes de defeitos em carvalho vermelho. Kline et al. (2003) desenvolveram uma máquina com múltiplos sensores para classificação de folhosas. Quoirin (2004) desenvolveu um software para o diagnóstico de imagens de madeira, capturadas por tomografia de raios-X, como técnica não-destrutiva de avaliação de defeitos. Gomes et al. (2008) desenvolveram um classificador de imagens para a identificação de defeitos de madeira serrada de eucalipto, usando linguagem C++ e um conjunto de bibliotecas de funções fornecidas pelos fabricantes da câmara. A taxa de acerto foi de $64,3 \%$, quando o referencial eram as normas da ABNT, e de $81 \%$ quando utilizada a padronização de serraria comercial.

Rall (2010), em sua tese de doutorado, desenvolveu um software, em linguagem Java, para classificação de tábuas de Pinus a partir de sua imagem digital. O software obteve um taxa de acerto de $90,50 \%$ na classificação de uma amostra de 84 tábuas. O software de processamento de imagens digitais, agilizou os processos de detecção, classificação dos defeitos (nós, medula e bolsa de resina) e das tábuas, com uma alta porcentagem de acerto. Essa taxa de acerto expressiva foi obtida com o uso de várias técnicas de análise de imagens associadas já que, como ficou demonstrado em sua tese, uma técnica isolada não se mostrou eficaz.

Trabalhos mais recentes têm reportado a utilização do aprendizado de máquina - modelos supervisionados de aprendizado com algoritmos de aprendizagem associados, que analisam os dados e reconhecem padrões - como por exemplo, redes neurais e SVM - Support Vector Machine, no aperfeiçoamento do desempenho dos softwares. Esses procedimentos necessitam de bancos de dados de imagens no processo de aprendizado. 
Khoury et al. (2006), desenvolveram redes neurais artificiais usando percentis das bandas vermelha, verde e azul, como Kauppinen (1999), para avaliação de 80 defeitos de madeira serrada de eucalipto e, dependendo do tamanho de blocos da imagem, obtiveram taxas de exatidão de 83,1\% (blocos de 64x64 pixels) e $76,6 \%$ (32x32 pixels).

Oliveira et al. (2008) desenvolveram método para a detecção de defeitos na madeira de Pinus, a partir de imagens capturadas com o auxílio de uma câmara tipo line scan e processadas para caracterização de cor e textura, como suavidade, aspereza e regularidade. Os autores utilizaram redes neurais e SVM e verificaram que imagens em níveis de cinza apresentaram desempenho mais competitivo em relação ao sensor colorido, de maior custo.

No âmbito comercial cabe destaque ao equipamento WoodEye Innovativ Vision. É um equipamento dotado de scanner óptico, baseado em espectro de luz e laser que capta, em tempo real, a imagem da madeira, alimentada no processo por meio de uma esteira. A imagem é processada digitalmente e o software do equipamento identifica e quantifica uma grande gama de defeitos (nós, medula, esmoados, distorções dimensionais, empenamentos), classificando a madeira e sugerindo eventuais planos de corte otimizados, para suas eliminações. 


\section{MATERIAL E MÉTODOS}

\subsection{Geração das imagens digitais e metadados para a base de dados}

Considerando que o objetivo deste trabalho foi o desenvolvimento de uma base pública de imagens digitais de tábuas de madeira de Pinus, associada a dados referentes a cada uma das imagens das tábuas - metadados - que detalham a espécie da madeira, procedência, idade, altura da árvore, posição da tábua na árvore, dimensões, defeitos, entre outros, foi delineado um método para esta etapa, composto por sete atividades:

1. Desdobro das árvores e processamento mecânico das tábuas

2. Montagem do ambiente para aquisição das imagens

3. Aquisição das imagens das tábuas

4. Definição e coleta dos metadados

5. Recorte das regiões pertinentes das imagens

6. Classificação das tábuas no software SAIMP

7. Caracterização das imagens e blocos de defeitos

Para povoar o banco de dados foram trabalhadas as imagens de tábuas de três grupos:

a) Grupo 1 - tábuas de madeira de Pinus taeda L. do Horto Florestal no município de Manduri - SP (latitude $23^{\circ} 00^{\prime}$ sul, longitude $49^{\circ} 19^{\prime}$ oeste e altitude $700 \mathrm{~m}$ ). Foram 
amostradas, ao acaso, seis árvores com aproximadamente 37 anos de idade, que produziram 84 tábuas com dimensões aproximadas de $225 \mathrm{~cm}$ de comprimento, $2,5 \mathrm{~cm}$ de espessura e larguras variando de 13,5 a $32,5 \mathrm{~cm}$;

b) Grupo 2 - tábuas de madeira de Pinus elliottii, também do Horto Florestal de Manduri. Foram amostradas três árvores, com aproximadamente 52 anos de idade (plantio de 1960), dentre as que apresentavam maior retidão do fuste e grande ocorrência de galhos na região da copa, que resultaram em 81 tábuas com dimensões aproximadas de $250 \mathrm{~cm}$ de comprimento, $2,5 \mathrm{~cm}$ de espessura e largura variando entre $12,0 \mathrm{~cm}$ e $30,5 \mathrm{~cm}$;

c) Grupo 3 - constituído pelas tábuas do grupo 2 após o processo de secagem em estufa a $12 \%$ de umidade e processamento mecânico de aplainamento das duas faces e refilamento das bordas em seu comprimento. O aplainamento das faces reduziu a espessura das tábuas de $2,5 \mathrm{~cm}$ para $2,0 \mathrm{~cm}$ e o refilamento de suas laterais diminuiu sua largura em cerca de $2,0 \mathrm{~cm}$.

\subsubsection{Desdobro das árvores e processamento mecânico das tábuas}

Todas as árvores estudadas nos três grupos foram derrubadas com o uso de motosserra, cortadas em toras com comprimento variando de 2,25m (grupo 1) a 2,5m (grupo 2) no próprio talhão e, na serraria do Horto Florestal de Manduri, foram desdobradas em tábuas.

As tábuas do Grupo 1 foram obtidas por Rall (2010) usando a metodologia descrita em sua tese de doutorado. Foram retiradas das costaneiras laterais esquerdas e direitas das toras, depois de eliminado o pranchão central com $6 \mathrm{~cm}$ de espessura. No total foram obtidas 84 tábuas com dimensões aproximadas de $225 \mathrm{~cm}$ de comprimento, $2,5 \mathrm{~cm}$ de espessura e larguras variadas. A madeira foi secada em um secador industrial da Madeireira Makenboy - Manduri, até atingir a umidade nominal de equilíbrio de $12 \%$.

Na marcenaria da Faculdade de Ciências Agronômicas da UNESP Botucatu/SP, as tábuas foram aplainadas, tiveram seus comprimentos retificados para 200 cm, com a manutenção de suas larguras variáveis entre 13,5 e 32,6 cm (média de 21,5 cm).

Todas as tábuas foram identificadas com um número seqüencial de 1 a 84 e foi mantida, adicionalmente, uma codificação com informações dos locais de sua 
retirada, considerando-se a árvore, a tora e a localização da tábua. A codificação era composta de letras e números que, em qualquer momento, se necessário, poderão ser associadas às propriedades encontradas e à localização na árvore. $\mathrm{O}$ primeiro dígito indicava a árvore e o segundo dígito, após a barra, indicava a tora. Nas tábuas, foi acrescentada uma identificação que representava o desdobro das costaneiras laterais das toras. As letras, "D" e "E", representavam, o lado direito e o lado esquerdo da tábua, respectivamente, seguida do dígito de cada tábua, retirada a partir das costaneiras laterais da tora, sempre do interior para o exterior, adicionando-se um número seqüencial. Assim, como exemplo, a tábua 2/1 D1 foi produzida da árvore 2, da tora $1\left(1^{\mathrm{a}}\right.$ da base para o topo da árvore), da posição "D” em relação a largura, sendo a $1^{\text {a }}$ tábua a partir da medula para casca.

As tábuas que compuseram o Grupo 2, conforme já comentado, foram obtidas de três árvores de Pinus elliottii, selecionadas no talhão dentre as que apresentavam maior incidência de galhos, buscando, com isso, enriquecer as amostras de defeitos no banco de dados. A Figura 11 apresenta uma vista geral do talhão escolhido e a Figura 12 ilustra as toras de 2,5m sendo empilhadas no pátio do Horto Florestal de Manduri, para posterior desdobro em tábuas.

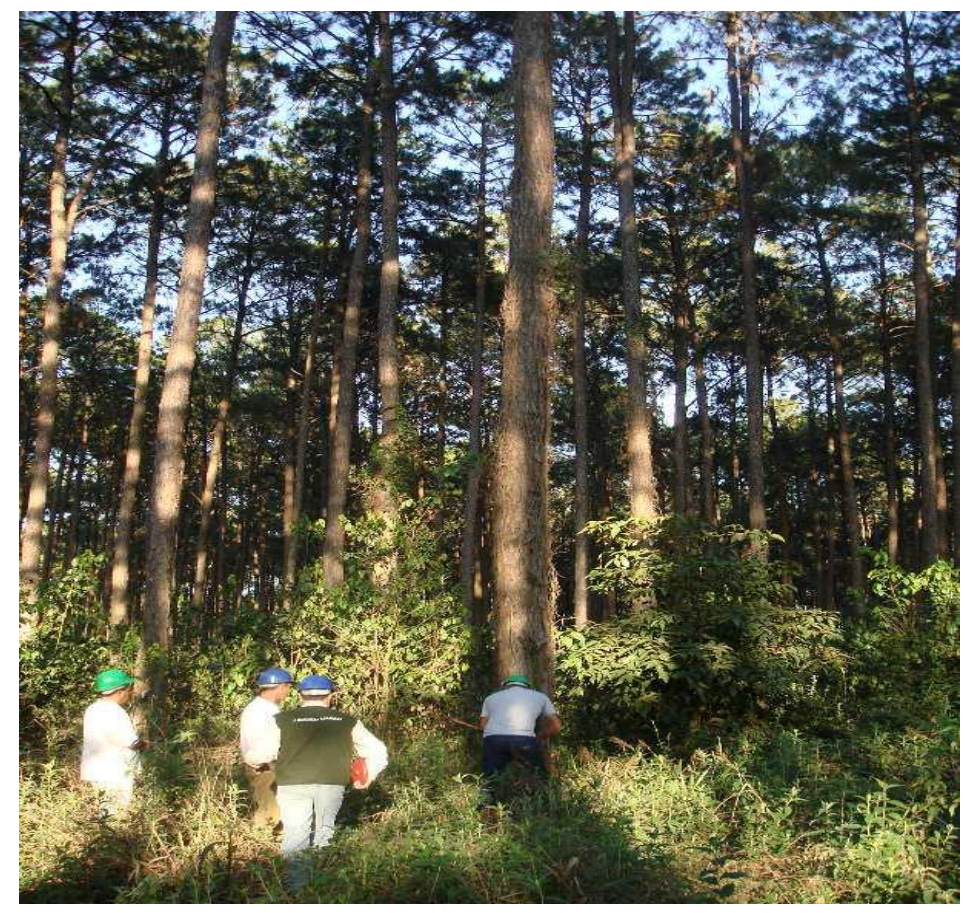

Figura 11 - Vista geral do talhão de Pinus elliottii Horto Florestal de Manduri. 


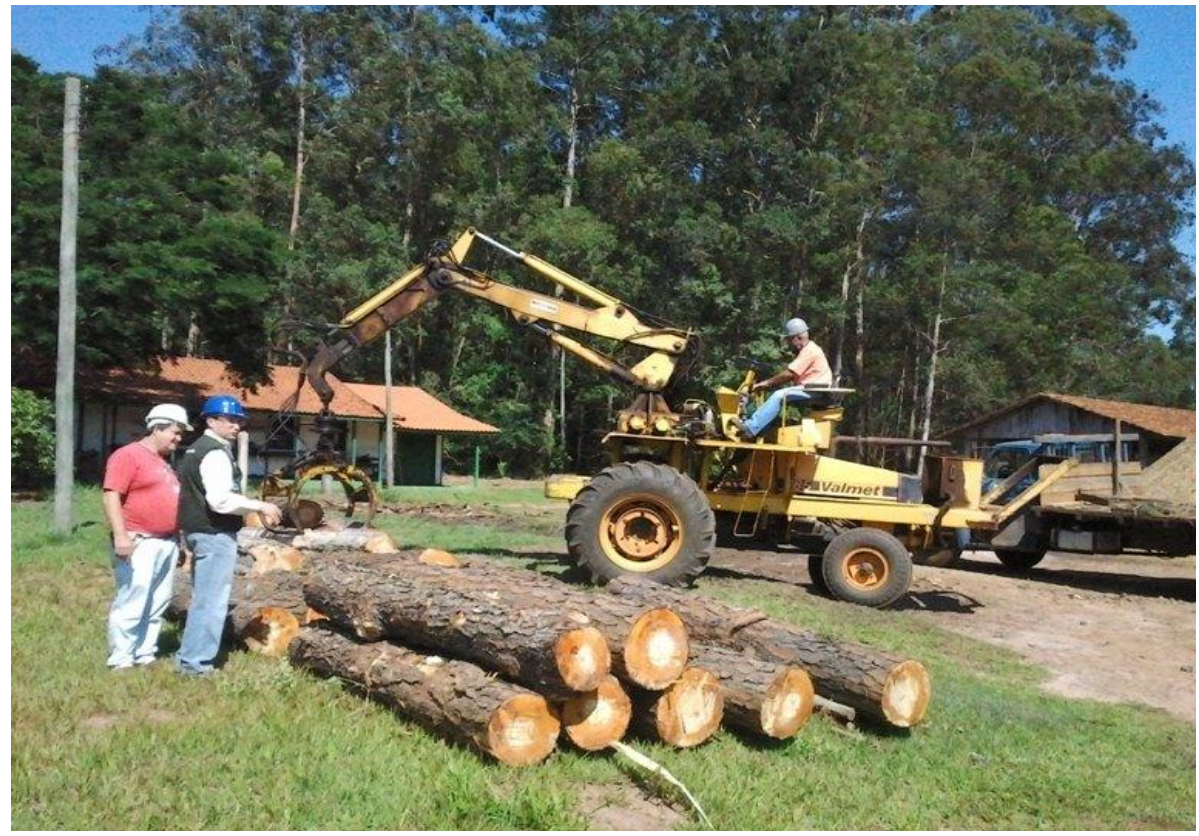

Figura 12 - Detalhe das toras de 2,5m de comprimento no pátio, para processamento mecânico.

As tábuas foram retiradas de todo o fuste das árvores, sem eliminação do pranchão central. Com esse procedimento, foram obtidas 81 tábuas das três árvores.

Também para o grupo 2 foi adotada uma codificação das tábuas, semelhante a já descrita para o grupo 1. Neste caso foi também usada a letra "C", para designar tábuas advindas da região central do fuste da árvore, conforme ilustrada na Figura 13.

As tábuas dos dois grupos receberam os códigos, aplicados com lápis de carpintaria nas suas bordas (topo), com a finalidade de não prejudicar a imagem digitalizada. 

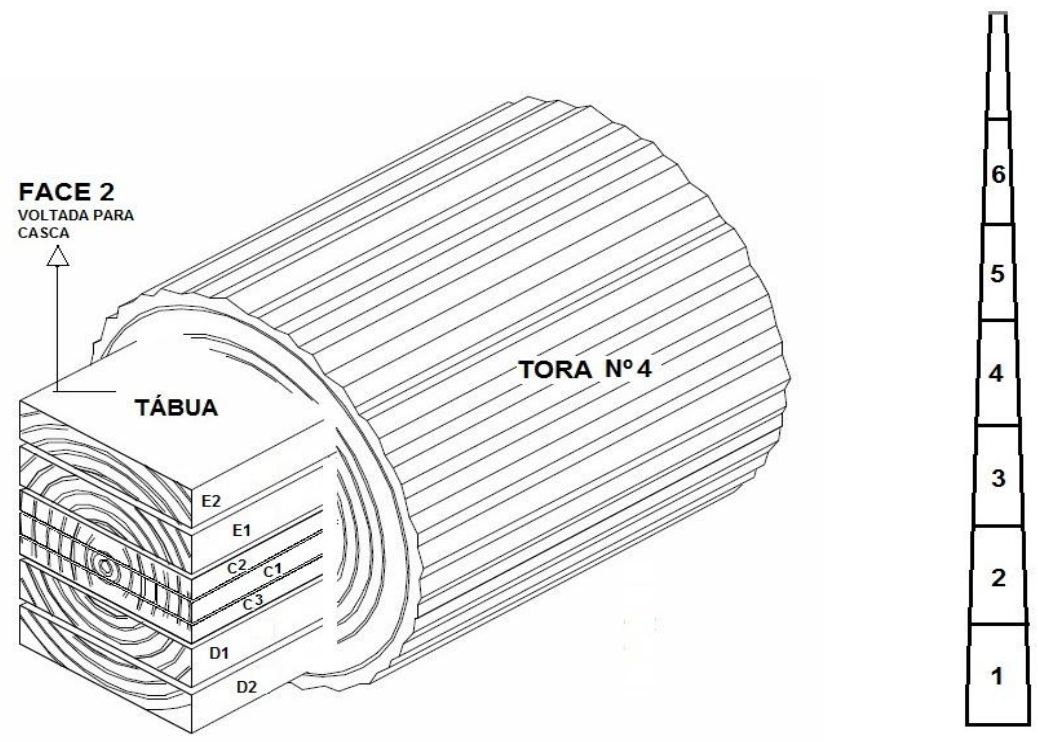

ÁRVORE $\mathbf{N}^{0} 1$

Figura 13 - Nomenclatura adotada para tábuas do grupo 2

Fonte: Rall (2010), com adaptação do autor.

A Figura 14 ilustra etapas do processamento mecânico das tábuas do Grupo 2, que compreendeu o desdobro na serra de fita dupla da serraria do Horto Florestal de Manduri e o refilamento.
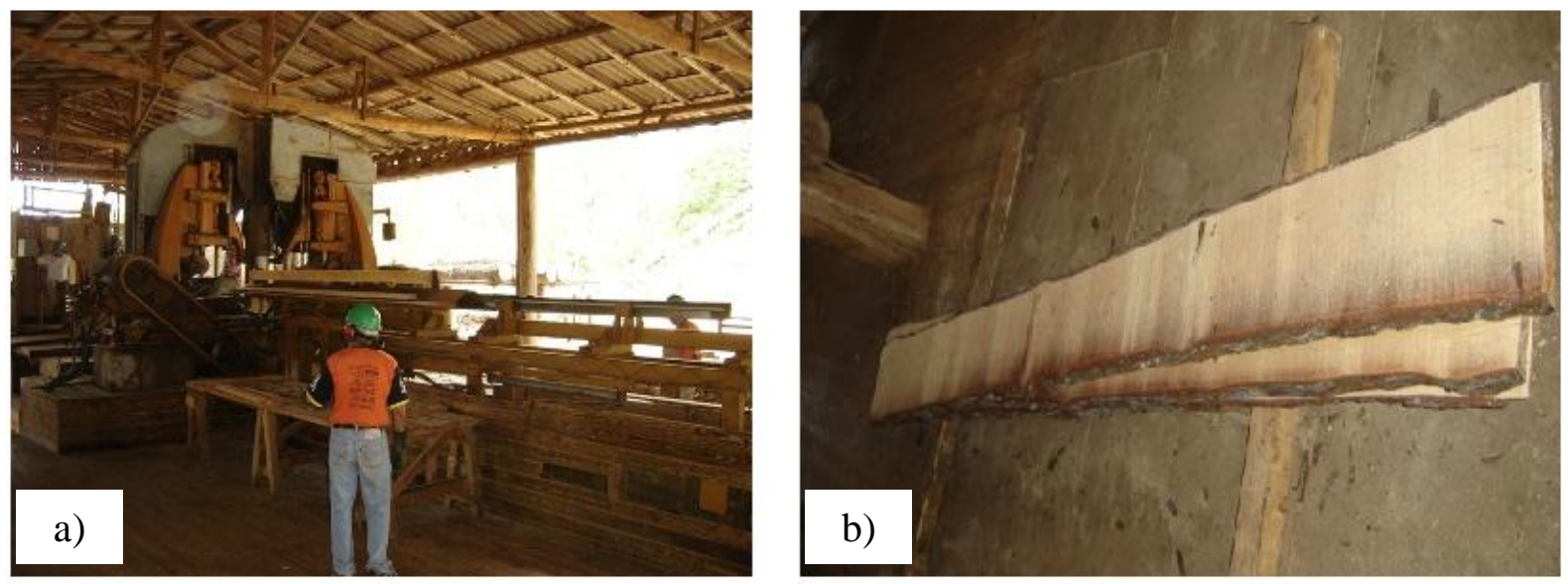

Figura 14 - Processamento mecânico das tábuas do grupo 2. a) vista geral da serra fita dupla. b) detalhe de algumas tábuas desdobradas, antes do refilamento.

As tábuas que compuseram o Grupo 3 são as próprias tábuas do Grupo 2 após a secagem e aplainamento. A secagem a um teor de umidade nominal de 
12\% foi realizada em secador industrial do Laboratório de Secagem e Preservação da Madeira do Departamento de Ciências Florestais - FCA/UNESP - Botucatu. O aplainamento foi realizado na carpintaria do Horto Florestal de Manduri - SP, por funcionários treinados para esse procedimento, conforme ilustra a Figura 15.

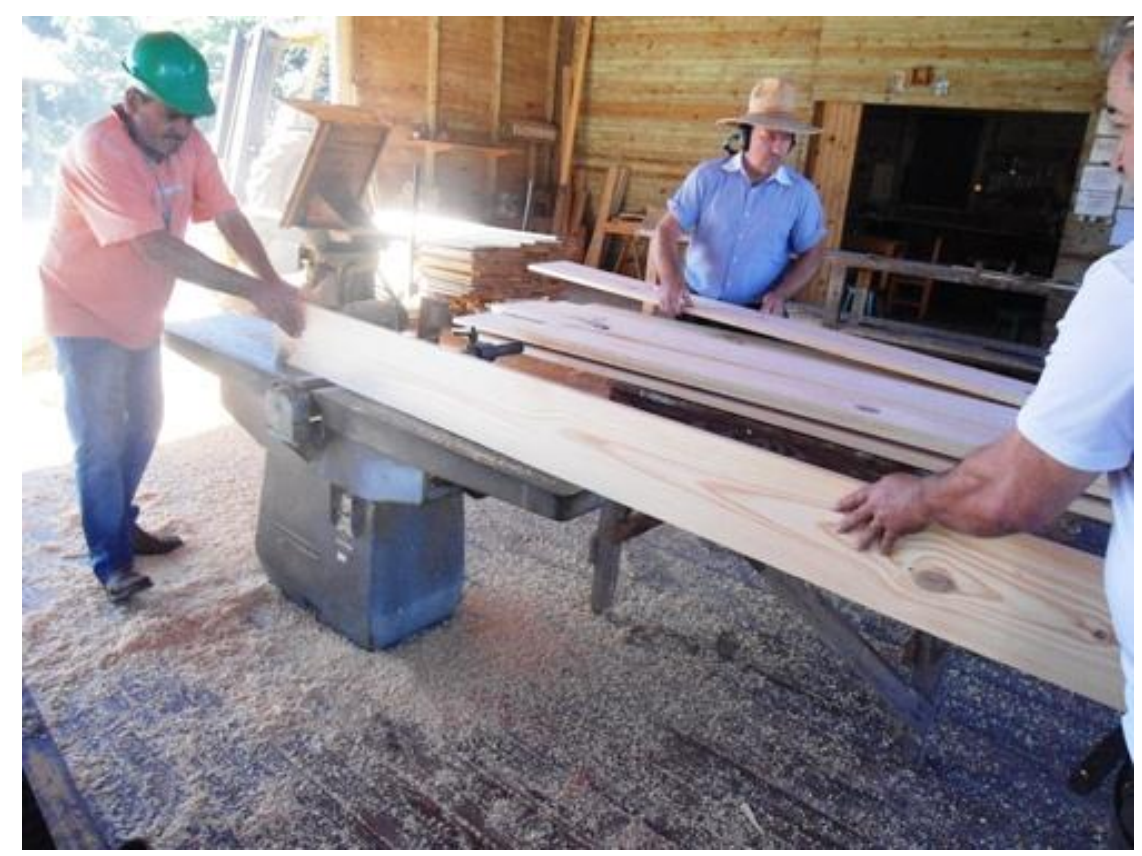

Figura 15 - Procedimento de aplainamento das tábuas na carpintaria do Horto Florestal de Manduri - SP.

\subsubsection{Montagem do ambiente para aquisição das imagens}

Todas as imagens digitais das tábuas foram produzidas em ambiente especialmente preparado para essa finalidade (estúdio), com estrutura especial de iluminação controlada, descrita e avaliada por Rall (2010), conferindo iluminância praticamente constante (média de 972 lux) em todo o campo. As Figuras 16 a 19 ilustram o aparato de sustentação da iluminação e outros detalhes do estúdio concebido. 


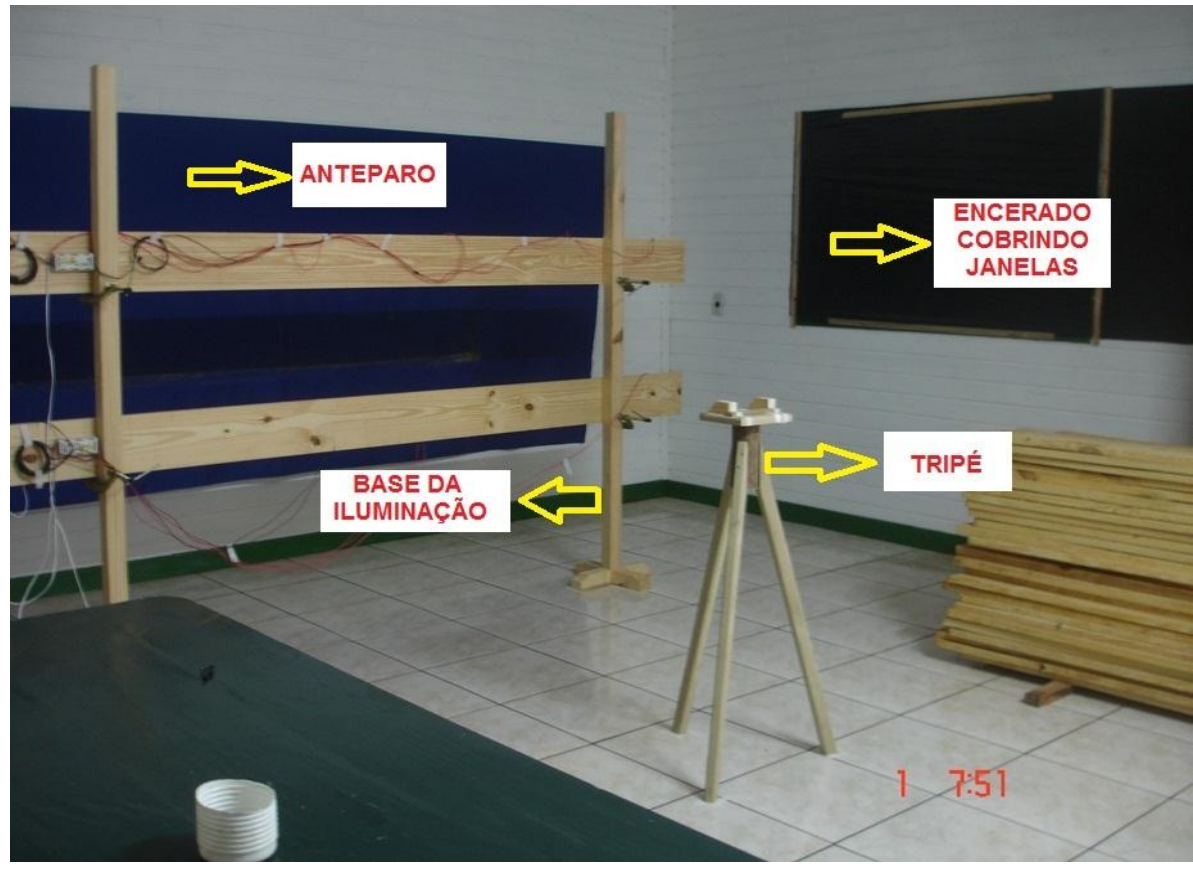

Figura 16 - Estúdio de aquisição de imagens

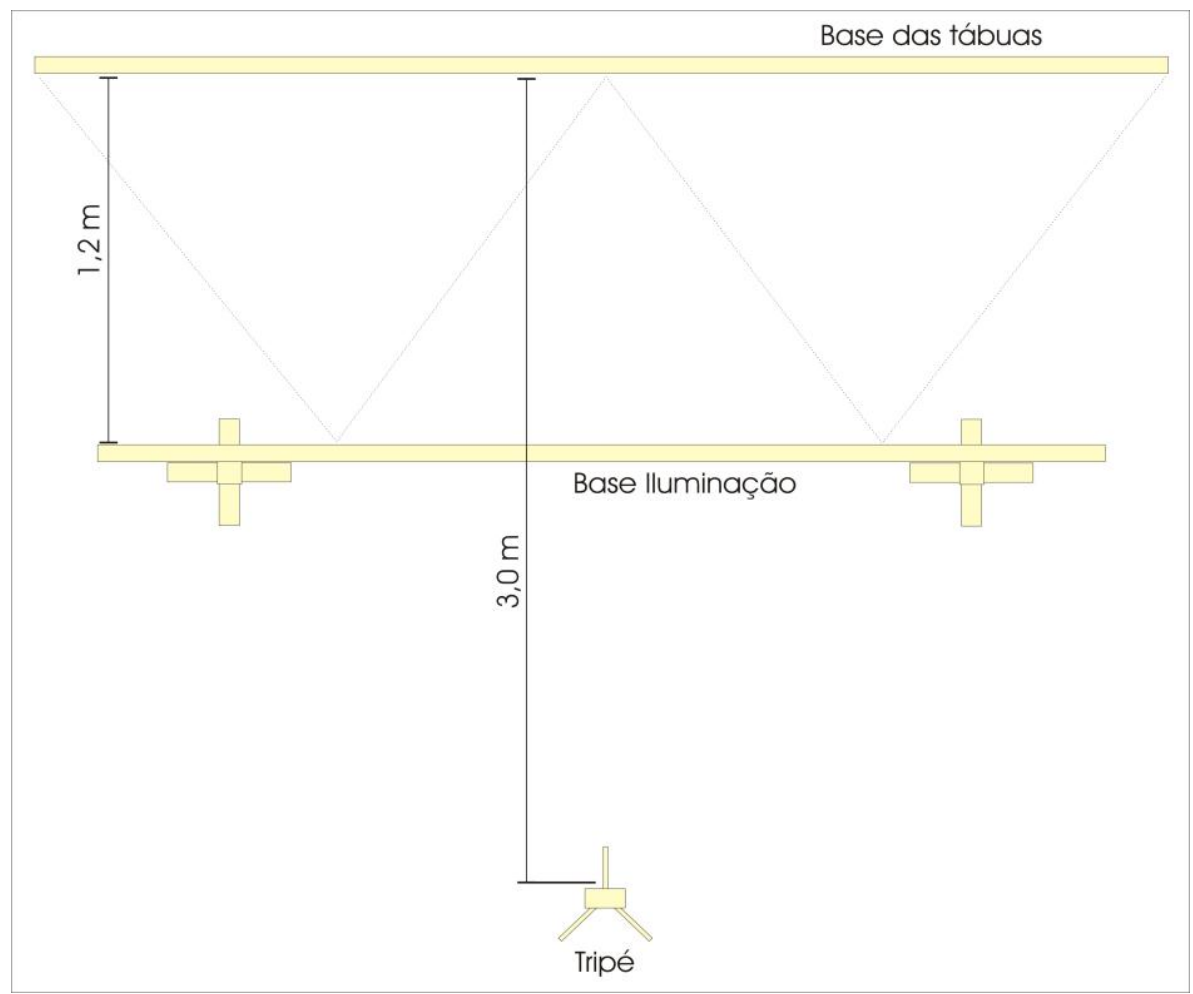

Figura 17 - Distribuição dos objetos no estúdio de aquisição de imagens 

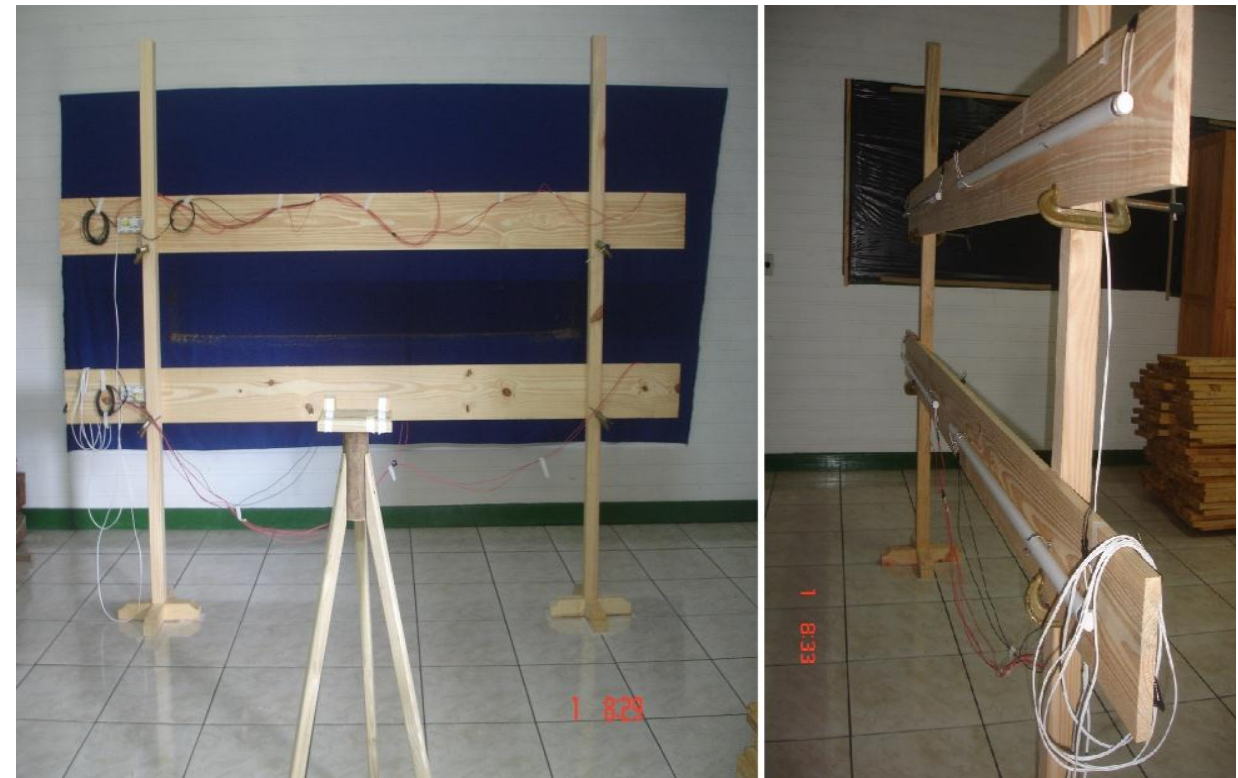

Figura 18 - Estrutura construída e instalada no ambiente de aquisição de imagens, para suporte e fixação da iluminação artificial.

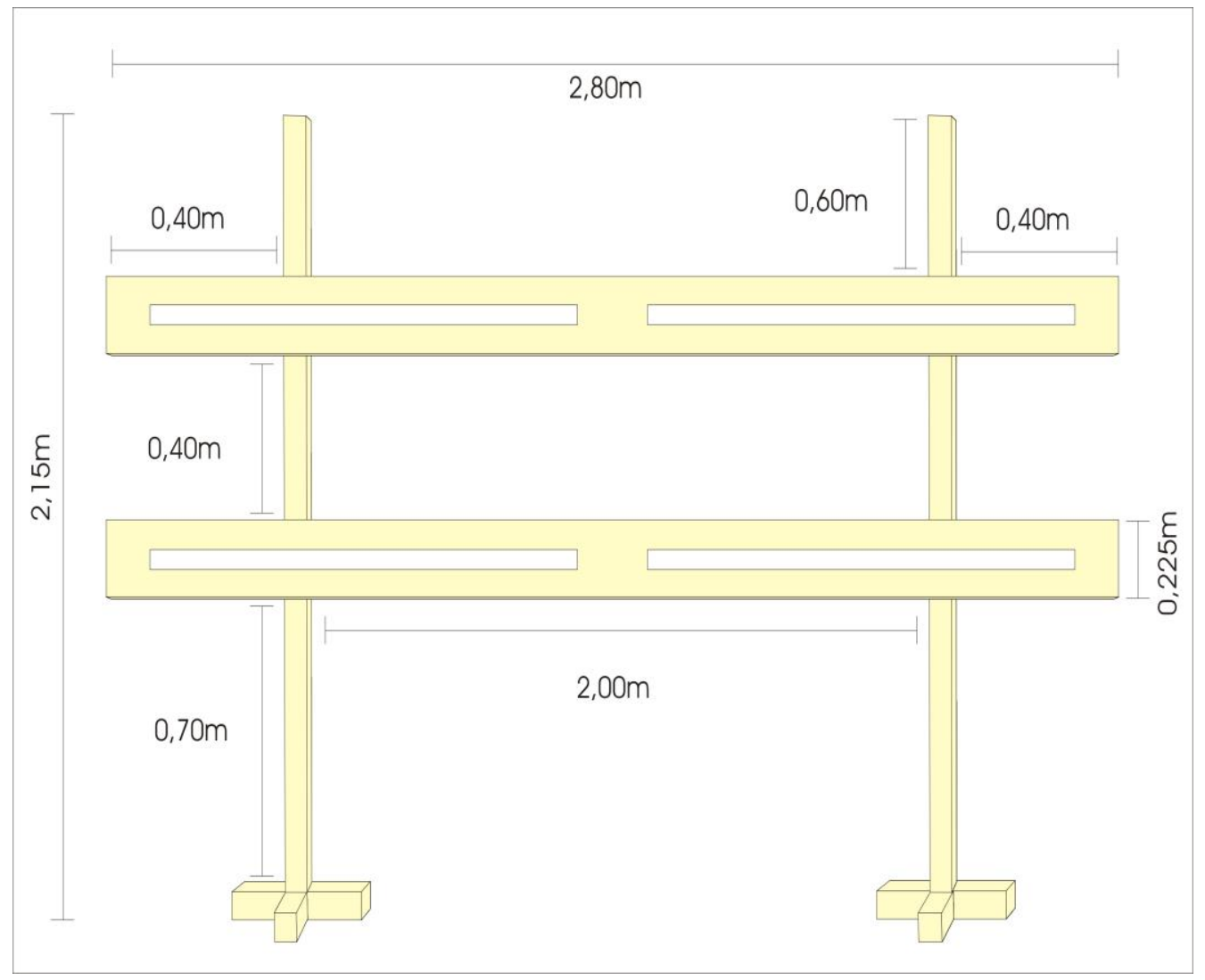

Figura 19 - Esquema da estrutura de suporte da iluminação. 


\subsubsection{Aquisição das imagens digitais das tábuas}

As imagens das tábuas do grupo 1 foram adquiridas por Rall (2010), com uso de câmera fotográfica marca Lumix, do fabricante Panasonic, modelo DMC-LZ26, com resolução máxima de 6 megapixels e zoom óptico de 6x. Todas as imagens foram adquiridas com a resolução de 6 megapixels, com dimensões 3072 x 2048 pixels, gerando arquivos do tipo "jpeg”, com tamanho aproximado de 2 megabytes. Maiores detalhes são descritos em Rall (2010).

As imagens das tábuas dos Grupos 2 e 3 foram adquiridas usando câmera digital semiprofissional de marca Sony modelo Cyber-Shot DSC-P93 de 5.1 Megapixels com flash embutido.

Para gerar uma base de dados com quantidade significativa de amostras de imagens de tábuas, foram coletadas imagens de 81 tábuas. Como foram fotografadas as duas faces das tábuas, esse processo gerou 162 imagens, das quais 12 imagens foram descartadas. A necessidade de obter as imagens das duas faces está no fato de que a classificação da tábua deve ser determinada pela face de pior qualidade, além de que a base de dados deve contemplar o maior número de defeitos para melhor servir ao aprendizado de máquina em softwares que utilizam técnica de inteligência artificial, ademais alguns defeitos presentes em uma face podem não se apresentarem na face oposta da tábua.

As imagens digitais das tábuas foram captadas com resolução aproximada entre 5.0 e 6.0 megapixels e foram armazenadas no formato JPEG, usando o sistema de cores RGB ( $\mathrm{R}$ - vermelho; $\mathrm{G}$ - verde; $\mathrm{B}$ - azul). Isso permite que as imagens mantenham todas as informações sobre cada pixel da imagem, em cada banda de cor RGB. Alguns formatos de imagens digitais podem provocar perda de informações, que eventualmente poderiam prejudicar a análise das imagens em etapas posteriores.

No momento da aquisição das imagens também foram obtidas algumas informações relacionadas à tábua, como a sua largura e o seu comprimento, além de ser anotado seu código, descrito anteriormente. Assim cada imagem foi vinculada há um conjunto de informações que constituirão os metadados das imagens das tábuas.

Em todas as aquisições (Grupos 1, 2 e 3) foi utilizado como fundo da imagem um tecido na cor azul escuro, que proporciona grande contraste com as tábuas. Foi acionado o zoom com ajuste de 0,1x, visando desligar o efeito da lente grande angular, 
presente em algumas câmeras, que distorce as linhas horizontais, na posição central da foto.

Os tripés de sustentação das câmeras foram: da marca Mirage, modelo Lander aplicado na coleta das imagens do Grupo 1 e outro, confeccionado em madeira, para coleta das imagens dos Grupos 2 e 3. Em todas as aquisições os tripés posicionaram as câmeras a $1,0 \mathrm{~m}$ de altura e a 3,0m de afastamento da tábua. A estrutura de iluminação foi posicionada a 1,2m de distância da tábua, conforme ilustrou a Figura 18.

As tábuas dos grupos 1,2 e 3 receberam tratamentos distintos e perfizeram quantidades diferentes de imagens entre os grupos, sendo tais dados sumarizados na Tabela 4.

Tabela 4 - Resumo da quantidade de imagens obtidas por grupo de tábuas

\begin{tabular}{ccccc}
\hline & Tratamento & $\begin{array}{c}\text { Quantidade } \\
\text { inicial }\end{array}$ & $\begin{array}{c}\text { Imagens } \\
\text { descartadas }\end{array}$ & $\begin{array}{c}\text { Quantidade } \\
\text { final }\end{array}$ \\
\hline Grupo 1 & $\begin{array}{c}\text { Refilamento } \\
\text { Destopamento } \\
\text { Secagem } \\
\text { Aplainamento }\end{array}$ & 84 & 0 & 84 \\
\hline Grupo 2 & Nenhum & 162 & 0 & 162 \\
\hline Grupo 3 & $\begin{array}{c}\text { Refilamento } \\
\text { Secagem } \\
\text { Aplainamento }\end{array}$ & 162 & 0 & 162 \\
\hline Total & & & & $\mathbf{4 0 8}$ \\
\hline
\end{tabular}

\subsubsection{Definição e coleta dos metadados}

Os dados mais relevantes nesta pesquisa são a imagem da tábua e os blocos de imagens que representam as regiões da tábua que apresentam defeitos. Uma imagem sem nenhum dado que a descreva - metadados - dados que descrevem dados (GIL et al, 2013) dificilmente expressa algum significado consistente. Por esse motivo, na estruturação do banco de dados escolhido um gerenciador que oferece uma estrutura que manipule dados multimídia e garante a consistência e a integridade das imagens durante os processos de pesquisa e recuperação das mesmas. As imagens foram armazenadas em 
campos BLOB do SGBD, utilizando o mecanismo de armazenamento de dados multimídia não interpretado, garantindo, assim, a consistência e integridade das imagens.

Adotou-se como código único para cada imagem o rótulo atribuído a tábua no momento do seu desdobro, sendo este dado o identificador principal de cada imagem. Outros dados, necessários para caracterizar a tábua e sua imagem digital, foram vinculados diretamente à tábua (dados diretos) ou associados a ela através de dependências indiretas (dados indiretos), conforme segue:

- Dados diretos: comprimento, largura e espessura, classificação na ABNT a qual a tábua se enquadrou após a análise visual ou por visão artificial, tipo de tratamentos aplicados como secagem e aplainamento.

- Dados indiretos: espécie, número da árvore e número da tora da qual foi extraída.

Conforme se pode inferir, alguns dados que compõem os metadados foram obtidos ou gerados a partir dos procedimentos realizados no próprio projeto(dimensões das tábuas, por exemplo) enquanto outros, como idade e espécie da árvore, foram obtidos das entrevistas e questionamentos feitos a funcionários e colaboradores que trabalham no local de coleta das amostras.

\subsubsection{Recorte das regiões pertinentes das imagens}

As imagens das tábuas foram adquiridas com todos os componentes que estão presentes no campo visual da câmera fotográfica, incluindo-se a estrutura de iluminação e o fundo (tecido azul). Como esses componentes não interessam ao projeto e nem devem povoar o banco de dados, fez-se necessária a extração deles, gerando uma segunda amostra com a imagem exclusiva da tábua.

Foi utilizada a ferramenta de corte de imagem disponível no software Microsoft Office Picture Manager, que é distribuído juntamente com o Office, pacote de softwares para escritório da Microsoft. Ao aplicar essa ferramenta para o recorte de imagens o software exige o ajuste dos limites para o corte, o que ele chama de "alças". Para o recorte das imagens das tábuas foram ajustadas suas alças de corte em: 0 pixels a esquerda, 0 pixels a direita, 800 pixels abaixo e 800 pixels acima. Gerando, após o recorte, uma imagem de 2592 pixels de comprimento por 344 pixels de largura. Reduzindo a imagem em aproximadamente $85 \%$ do seu tamanho original em bytes, originado um novo 
arquivo com aproximadamente 300 kilobytes. Essa redução, da imagem original para imagem final, é melhor visualizada nas Figuras 20 e 21. Por fim a imagem foi gravada em formato JPEG, com nome diferente do nome da imagem original, gerando, assim, um segundo arquivo de imagem, mantendo a imagem original intacta, para futuros trabalhos.

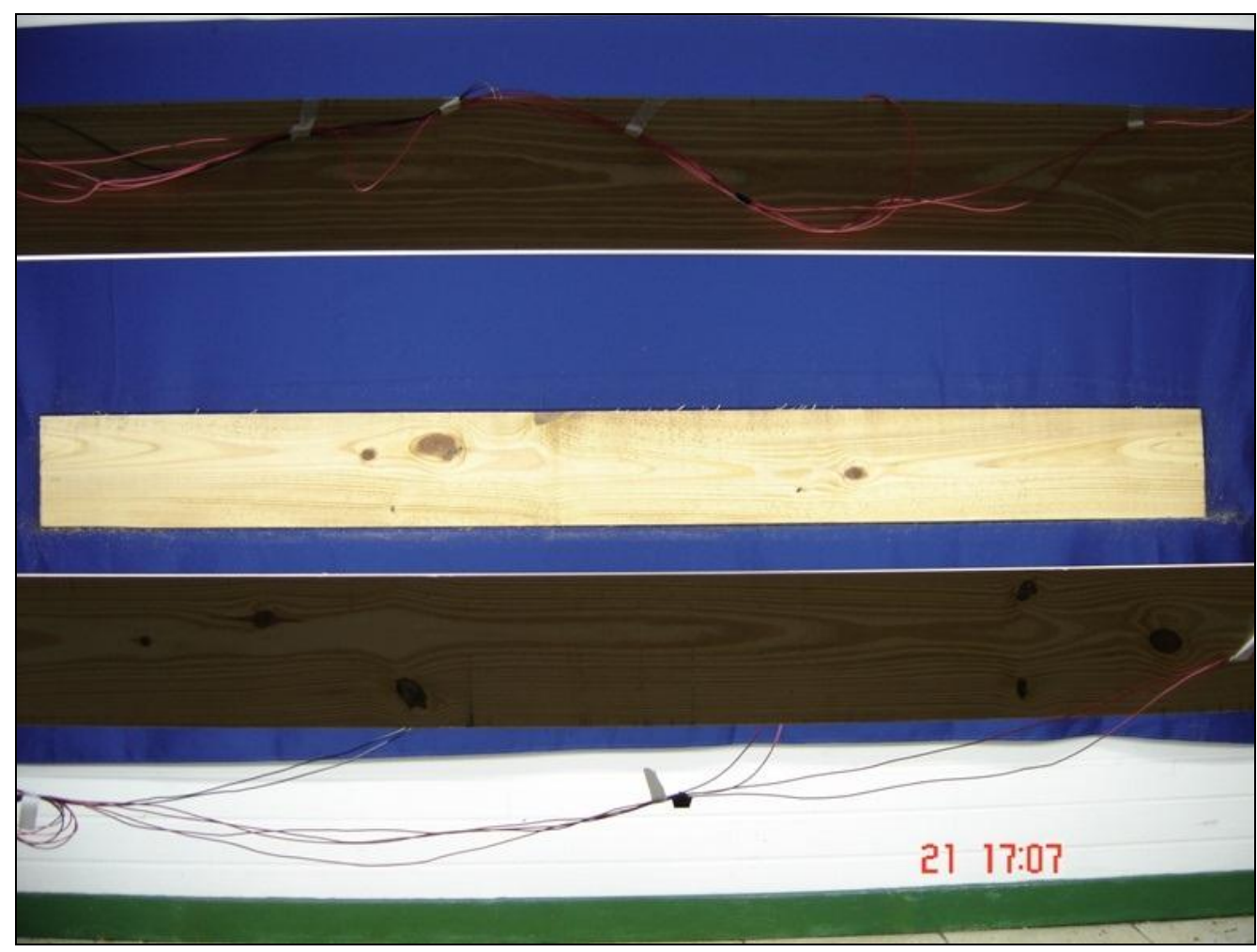

Figura 20 - Imagem digital original da tábua antes do recorte

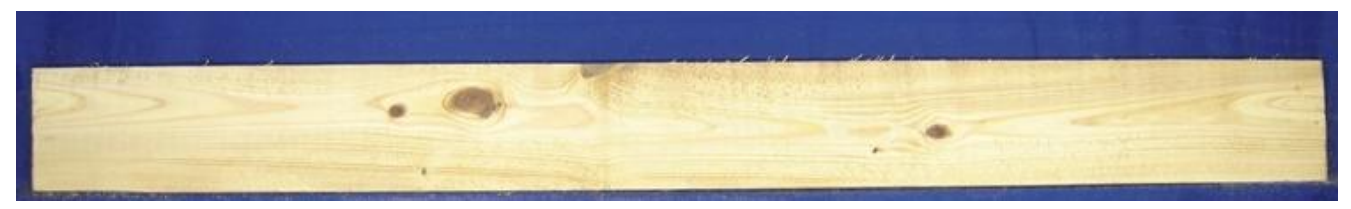

Figura 21 - Imagem digital após recorte no Microsoft Office Picture Manager

\subsubsection{Classificação das tábuas}

Antes do armazenamento das imagens no banco de dados foi realizada a classificação das imagens. Esse processo de classificação se fez necessário para que o banco de dados contemplasse não apenas imagens de tábuas e seus defeitos, mas também o efeito da incidência de tais defeitos nas tábuas, no âmbito da classificação de tábuas de madeira quanto a sua qualidade. 
O processo ocorreu de forma distinta para cada grupo de imagens trabalhado nesse projeto. A classificação das tábuas do grupo 1 foi realizada e descrita por Rall (2010). Primeiramente, através de visão humana, seguindo-se metodologia específica indicada na ABNT e, em seguida, automaticamente, com uso do software SAIMP, também desenvolvido por Rall (2010). A classificação por visão humana está sumarizada na Tabela 5 .

Tabela 5 - Classificação das tábuas do grupo 1

\begin{tabular}{lcc}
\hline Classe & Ocorrências & Porcentagem \\
\hline Super & 16 & 19 \\
Extra & 0 & 0 \\
Primeira & 41 & 49 \\
Segunda & 27 & 32 \\
Terceira & 0 & 0 \\
\hline Geral: & 84 & 100 \\
\hline
\end{tabular}

Parte das tábuas do grupo 2 foi classificada por meio de suas imagens digitais colhidas anteriormente. Foi empregado o mesmo método utilizado na classificação por visão humana e seguindo a norma específica, porém a medição das dimensões dos defeitos foi feita através de ferramenta de seleção do software de edição de imagens GIMP, em sua configuração padrão, sem necessidade de calibração. Esse software indica, ao se circundar uma região da imagem, o seu tamanho na unidade de medida que se desejar. Sendo assim, com a imagem da tábua na área de trabalho do GIMP selecionou-se, com a ferramenta de seleção retangular, a imagem da tábua em seus limites: superior, inferior, esquerdo e direito, excluindo o fundo azul que acompanha a imagem e registrando suas medidas em centímetros. Em seguida foram circundados os defeitos, um a um, e registrado suas medidas, também em centímetros. De posse dessas medidas foram computadas as porcentagens que a região de defeito ocupa na imagem da tábua como um todo, como especifica a norma. Para auxiliar no registro dos valores medidos, na construção das fórmulas e na execução dos cálculos, foi criada uma planilha com o uso do software Microsoft Excel.

Nesse processo de classificação das tábuas de todos os grupos não foram contemplados defeitos como encanoamento, arqueamento, encurvamento e esmoado, os quais dependeriam de imagens em diversos ângulos ou em três dimensões, o que não era objetivo deste trabalho. As tábuas que apresentaram tal defeitonão foram 
classificadas, porém foram armazenadas no banco de dados para compor a base de dados com diversidade imagens digitais de defeitos.

\subsubsection{Caracterização das imagens e blocos de defeitos}

A etapa seguinte à aquisição das imagens das tábuas consistiu em pré-avaliação das imagens com o programa GIMP (GNU Image Manipulation Program), que é um software de distribuição gratuita para manipulação e criação de imagens. Foram analisadas as imagens, buscando a detecção de problemas na aquisição, que pudessem prejudicar etapas posteriores do processo, devido à baixa qualidade da imagem. Foram encontradas imagens que apresentavam distorções geradas pelo equipamento, imagens com interferência de objetos que adentraram o campo visual no ato da coleta, entre outras. Tais imagens foram descartadas, reduzindo a amostra dos Grupos 2 e 3 de 324 imagens para 298 imagens. Uma porcentagem de erro (em torno de 8\%) não significativa para um processo estritamente manual e plenamente suscetível ao erro humano.

Ainda com uso do GIMP foram selecionadas e duplicadas porções menores das imagens das tábuas - regiões que apresentavam defeitos - gerando arquivos menores de imagens digitais, relacionados e associados à tábua original, que representaram os defeitos encontrados nas tábuas. Tais blocos foram classificados segundo os tipos de defeitos destacados pela norma NBR-12297 (ABNT, 1991a). Isso permitiu gerar um conjunto de imagens digitais, correlacionada apenas aos defeitos das tábuas de madeira, criando um catálogo dos principais defeitos encontrados em tábuas de Pinus, basicamente os nós, as medulas e as bolsas de resina.

Além dos blocos de defeitos, foram criados blocos de imagens de regiões sadias, mantendo-se, igualmente, os vínculos com as informações de suas imagens de origem. Como há uma variação visual entre as imagens das tábuas de madeira sadia, a seleção de conjuntos de imagens contemplando madeira sadia pode contribuir com a análise da imagem como um todo.

\subsection{Desenvolvimento do banco de dados de tábuas}

Após aquisição das imagens e a determinação das informações que são armazenadas sobre as imagens - metadados -, foi iniciada a etapa de modelagem e 
definição da base de dados multimídia. Para isso foram utilizadas ferramentas gratuitas e proprietárias. Algumas dessas ferramentas são específicas para modelagem de dados como o MySQL Workbench e BrModelo, já outras não, como o Microsoft Excel e Word. No capítulo 5 são apresentados os documentos criados para o banco de dados de imagens digitais de tábuas de Pinus:

- modelo conceitual - foi utilizado o BrModelo, que é uma ferramenta computacional de apoio a engenharia de software, conhecida como ferramenta CASE (Computer Aided Software Engineering), de distribuição gratuita.

- modelo lógico - representado pelo diagrama de entidades e relacionamentos - DER foi empregada ferramenta gratuita, também categorizada como ferramenta CASE, chamada MySQL Workbench, que contém ferramentas de apoio a geração da estrutura das tabelas, além de ferramentas que geram os relacionamentos entre as elas e as restrições impostas pelas regras de negócio ao projeto do banco de dados.

- modelo físico - documento textual que contém os comandos utilizados para construção da estrutura física do banco de dados na sequência lógica, em linguagem SQL, conhecido como "script de comandos". Tal documento, se aplicado corretamente, cria uma cópia exata da estrutura do banco de dados. Esse documento foi gerado por ferramenta específica para exportação de script constante no SGBD MyQSL, empregado em na construção do banco de dados.

- dicionário de dados - planilha que lista e descreve os campos de cada tabela do banco de dados. Esse documento foi construído com a utilização do Microsoft Excel.

\subsection{Construção e povoamento do banco de dados no SGBD}

Após a modelagem do banco de dados, foi realizada a implementação desse banco de dados no MySQL, formado por tabelas, que são capazes de receber os dados (imagens e seus metadados), armazená-los, organizá-los e prover ferramentas de pesquisa para as consultas e obtenção desses dados.

O banco de dados é atualmente mantido em um computador portátil até que seja possível transferi-lo a um equipamento mais robusto, para que possa ser disponibilizado ao público em geral, para consulta em um sistema web. Nesse sentido, já existe um estudo junto ao STI da FCA - Serviço Técnico de Informática da Faculdade de 
Ciências Agronômicas - UNESP - Botucatu, analisando a possibilidade de uso de um de seus equipamentos para hospedar e disponibilizar o banco de dados.

Após os testes de funcionalidade do banco de dados, realizados com poucos dados, seguiu-se o povoamento do banco com os dados reais, finalizando o processo de desenvolvimento do banco de dados.

A Figura 22 ilustra a tela de implementação do sistema de gerenciamento de banco de dados MySQL, no momento do desenvolvimento do banco de dados do projeto e com detalhe de uma tabela em construção.

Foram usadas duas ferramentas de ambiente gráfico para implementar o banco de dados no MySQL. Tais ferramentas apresentam o sistema de gerenciamento de banco de dados de uma forma mais amigável e faz uso de recursos gráficos para facilitar o trabalho do desenvolvedor. As ferramentas usadas foram o MySQL Query Browser e o MySQL Workbench. O MySQL Query Browser é uma ferramenta mais antiga e de domínio já adquirido, por isso a escolha pela mesma na construção do banco de dados. A ferramenta MySQL Workbench tem a mesma finalidade da citada anteriormente, porém é recente e necessita de mais tempo para adaptação. Mesmo assim optou-se por usála, pois ela disponibiliza um ambiente gráfico mais rico e ferramentas integradas de modelagem e implementação do banco, além de dispor recurso de engenharia reversa ${ }^{1}$, a qual foi utilizada para gerar novas versões do DER.

O banco de dados recebeu dados multimídia (imagens das tábuas dos Grupos 1 a 3 e de seus blocos de defeitos) e dados textuais (os metadados).

\footnotetext{
${ }^{1}$ Consiste no processo de geração do projeto a partir da análise e detalhamento de um produto final.
} 


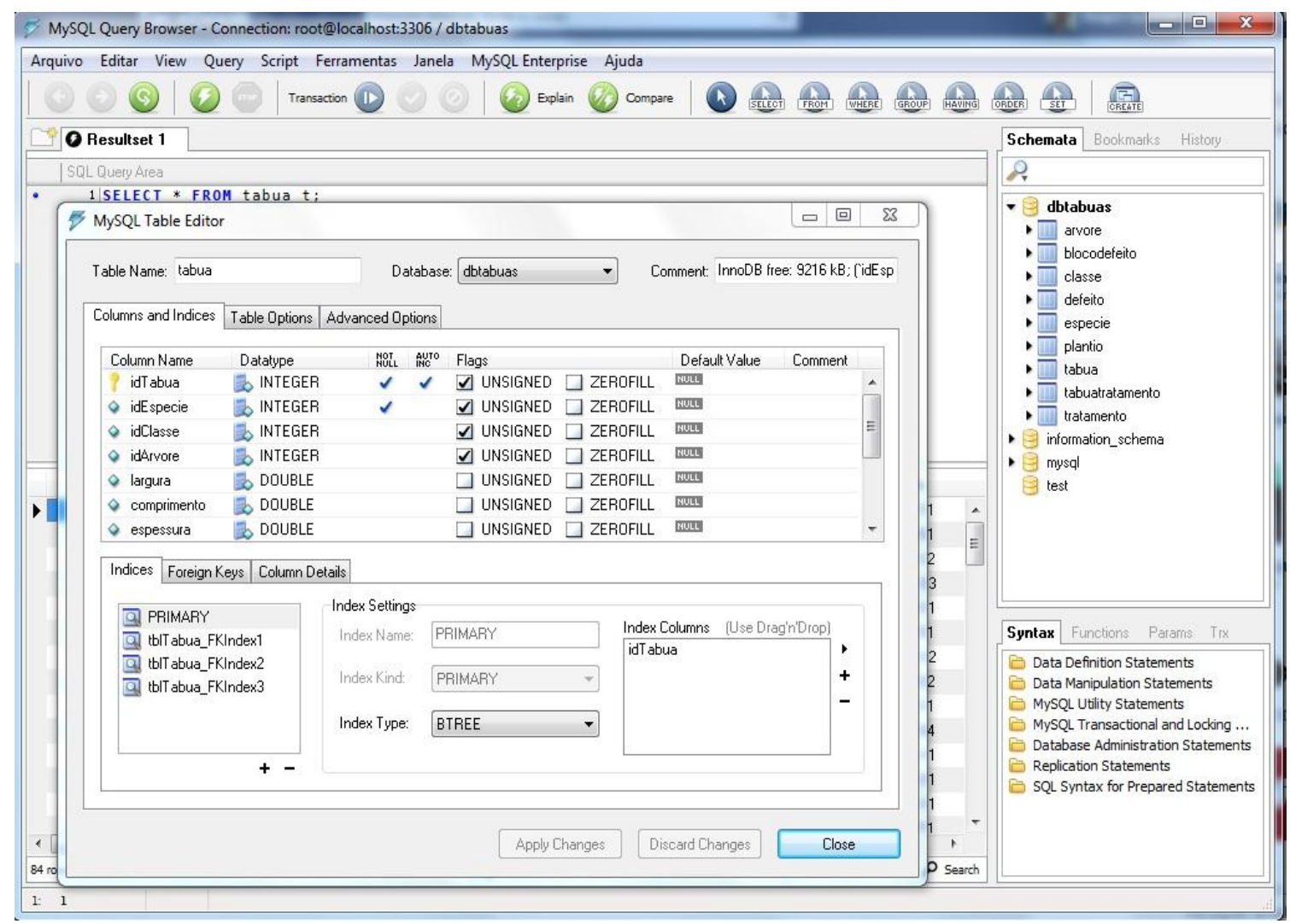

Figura 22 - Tela de implementação do SGBD MySQL.

\subsection{Desenvolvimento do sistema web}

O sistema foi desenvolvido usando a linguagem de programação Java. Para isso foram utilizados os softwares gratuitos NetBeans e GlassFish. O NetBeans é um ambiente de desenvolvimento integrado que permite a criação de softwares e, em especial, tem suporte a Java, que foi a linguagem utilizada no. O GlassFish é um repositório de aplicações que permite a execução de sistemas web desenvolvidos em Java. No desenvolvimento foi utilizado o mesmo computador que recebeu as imagens das tábuas e implementou o banco de dados. Nele já estava instalada a versão do Java para o desenvolvimentos de sistemas web, além dos demais programas citados.

Foram previamente analisadas e detalhadas as funcionalidades que o sistema deveria apresentar, que compreendiam ações de inserção de dados e imagens no sistema por um administrador, consulta das imagens e metadados armazenados e recuperação das imagens, segundo um determinado critério de consulta e pesquisa. Assim, a recuperação e a inserção de imagens no sistema foram desenvolvidas como um serviço $w e b$, podendo essas funcionalidades serem utilizadas de maneira independente, desde que 
atendidas às exigências dessas ações. Isso originou critérios para gerar solicitação de uso das funcionalidades e critérios para gerar as respostas e resultados das operações realizadas. Por fim, a etapa de desenvolvimento envolveu a criação dos códigos fontes, que executam as ações propriamente ditas e a sua ligação com todas as telas definidas para o sistema, além da conexão com o sistema gerenciador de banco de dados, para realizar o acesso às informações da base de dados de imagens. A etapa seguinte foi a de especificação e execução de testes funcionais do sistema. Foram gerados roteiros de uso do sistema, baseados no detalhamento de especificações do sistema web e da base de dados. Foram, ainda, definidos pares de itens a serem analisados, contendo as ações a serem executadas no sistema e as respectivas respostas esperadas, visando à detecção de problemas e erros, que exigiram ajustes, de maneira a atender as expectativas e necessidades previamente estabelecidas.

Com o sistema testado e validado, foram inseridas as informações (imagens e metadados) coletadas. Essa ação permitiu uma última avaliação de carga do sistema antes de sua disponibilização, colocá-lo em produção (abrindo-o para uso público).

Conforme já comentado, pretende-se disponibilizar publicamente o sistema web, com o apoio do STI-FCA/UNESP - Botucatu. 


\section{RESULTADOS E DISCUSSÃO}

\subsection{Imagens originadas pelo processo de coleta}

Conforme demonstrado na Tabela 4 , foi gerada uma população de 408 imagens de tábuas de Pinus taeda L. e elliottii. Além das imagens das tábuas, o banco de dados recebeu as imagens de blocos de defeitos extraídos das imagens das tábuas, que geraram um catálogo digital de amostras de defeitos como medula, nó e bolsa de resina. No desdobro das árvores e classificação dos defeitos percebeu-se que foi difícil encontrar tábuas com defeitos como furo de inseto, manchas, bolsa de resina, entre outros. Isso dificultou a catalogação de tais defeitos por intermédio de imagens digitais colhidas do mesmo talhão.

A Figura 23 apresenta algumas das imagens do grupo 3 (tábuas de Pinus elliotti desdobradas, aplainadas e refiladas), após sua manipulação no software de edição de imagens, para destacar a tábua dos demais componentes, e no estado em que foram armazenadas no banco de dados. É fácil observar que o defeito de maior incidência nas tábuas é o nó em primeiro lugar e em seguida a medula. Também, devido à escolha da espécie de Pinus elliottii para esse grupo, não é difícil encontrar bolsas de resina nas tábuas, já que a espécie tem essa característica.

A variação na largura das tábuas, foi devida à variação do diâmetro das toras originais. 

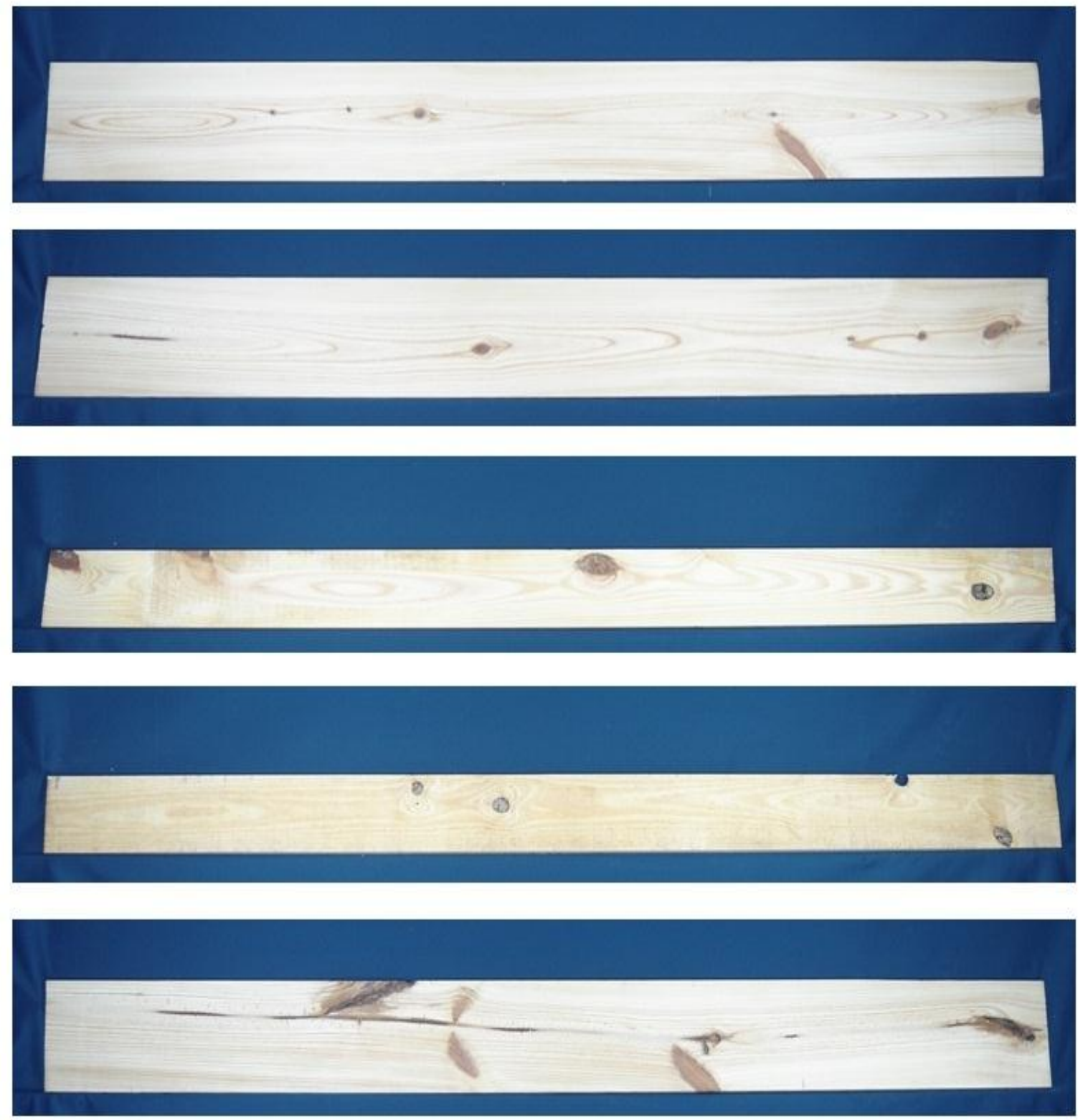

Figura 23 - Imagens das tábuas do grupo 3 após manipulação para armazenamento no banco de dados

As Figuras 24a a 24g demonstram a imagem digital do detalhe dos diversos defeitos e seus tipos, tais imagens foram extraídas das imagens originais de tábuas do grupo 3, colhidas para o projeto, e estão apresentadas como foram armazenadas no banco de dados.

Notam-se os diferentes tipos de nós, sendo que a Figura 24e apresenta o nó vazado posicionado na borda da tábua, que fica evidenciado devido ao realce com o fundo azul utilizado na coleta das imagens. Também se percebe a dificuldade 
em diferenciar os tipos de nós entre si, dificuldade maior encontrada durante a caracterização entre um nó cariado e um nó firme, e entre um nó cariado e um nó solto.

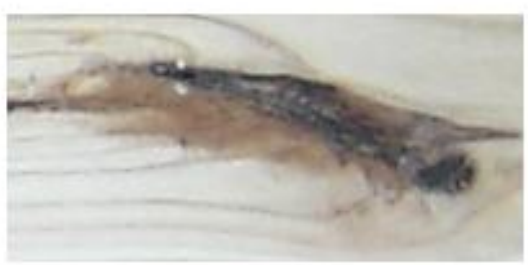

a) Bolsa de resina

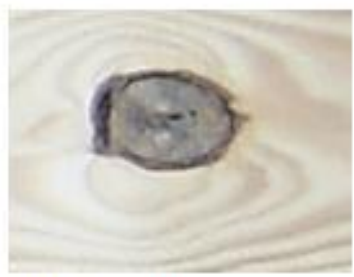

d) Nó solto

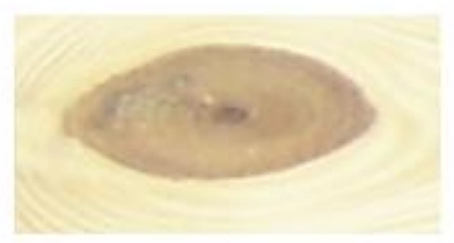

b) Nó firme

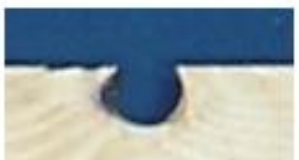

e) Nó vazado

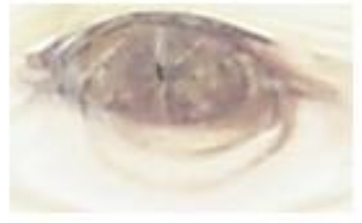

c) Nó cariado

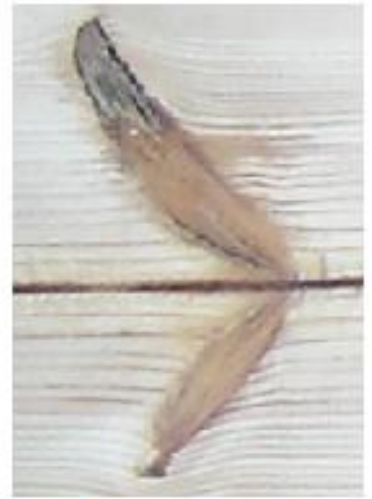

f) Nó de gravata

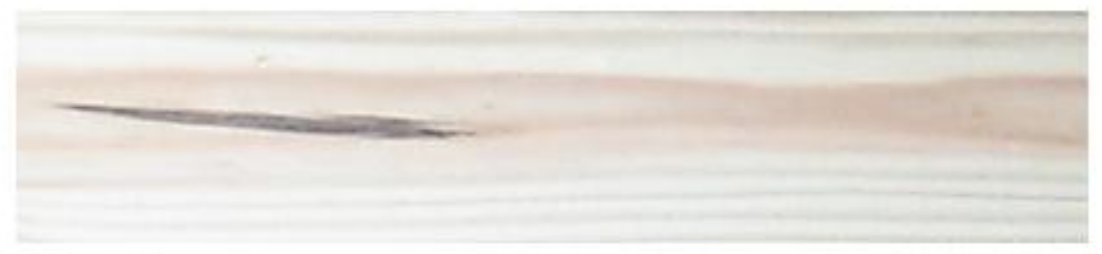

g) Medula

Figura 24 - Detalhe de alguns defeitos apresentados nas imagens colhidas

\subsection{Classificação das imagens através do software SAIMP}

Os resultados da classificação de parte das tábuas dos grupos 2 e 3, que foi classificada aplicando-se o método de classificação visual sobre as suas imagens digitais, está sumarizado em uma planilha elaborada no software Microsoft Excel no Apêndice 1.

As tábuas do grupo 1 (84 tábuas no total) foram, além de sua classificação por método visual aplicando-se a norma vigente, classificadas pelo software SAIMP (RALL, 2010). Os resultados da classificação está apresentado no Apêndice 2. 


\subsection{Modelagem do banco de dados}

Nesse processo foram os gerados documentos textuais e gráficos que descrevem o sistema e são utilizados para possíveis alterações e remodelagem, conforme descrito nos materiais e métodos. Esses documentos, juntamente com as tecnologias, os softwares empregados no desenvolvimento e manipulação do banco de dados, além dos arquivos que armazenas as tabela com os dados, compõem o banco de dados.

\subsubsection{Modelo conceitual do banco de dados}

O objetivo principal na construção desse modelo conceitual foi prover um documento, de fácil entendimento, sobre a estrutura proposta para concepção do banco de dados do projeto. A ferramenta BrModelo, que é de distribuição gratuita, utilizada para construções do presente modelo conceitual, se mostrou eficiente e de fácil manipulação, além de disponibilizar os recursos gráficos necessários para sua geração. Outra ferramenta que poderia ter sido usada é o software Visio da Microsoft, mas não foi adotado por ser uma ferramenta paga e apesar de prover recursos mais avançados, os mesmo não seriam necessários para construção do modelo em questão, não justificando sua aquisição.

Neste documento estão apresentadas, de forma gráfica, as entidades que são componentes principais do banco de dados (por retângulos), suas características (por pequenas circunferências) e suas relações básicas (por losangos). Cada retângulo representa uma entidade que compõe o banco de dados de imagens de tábuas que necessita ser armazenado. Esses retângulos representam as tabelas a serem criadas quando do desenvolvimento do banco de dados. Os atributos (características) de cada entidade são representados por pequenas circunferências e o atributo identificador por uma circunferência preenchida na cor preta. $\mathrm{Na}$ fase de desenvolvimento do banco de dados os atributos recebem o nome de campos, sendo que poderão surgir novos atributo, pois, no modelo conceitual, são suprimidas algumas informações técnicas para facilitar o entendimento. Pelas especificações do banco de dados sua principal entidade é a de 
Tábuas, a qual se relaciona direta ou indiretamente com todas as outras entidades. Tais relações são representadas pelos losangos e podem ser observados no modelo construído.

O resultado final é um documento gráfico consistente, que atinge seus objetivos, representando de forma simples a integração entre os componentes do banco de dados.

Uma relação entendida mais facilmente na representação gráfica do que na textual pode ser exemplificada pela relação que existe entre uma tábua e os tratamentos que ela pode receber, outra relação que também exemplifica é a existente entre a tábua e os defeitos existentes. Além de evidenciar quais atributos devem ser armazenados de cada entidade para que possa ser bem caracterizado.

A Figura 25 apresenta o resultado da construção do modelo conceitual construído para o banco de dados de imagens digitais de tábuas de Pinus proposto no projeto, utilizando-se a ferramenta gratuita BrModelo. 


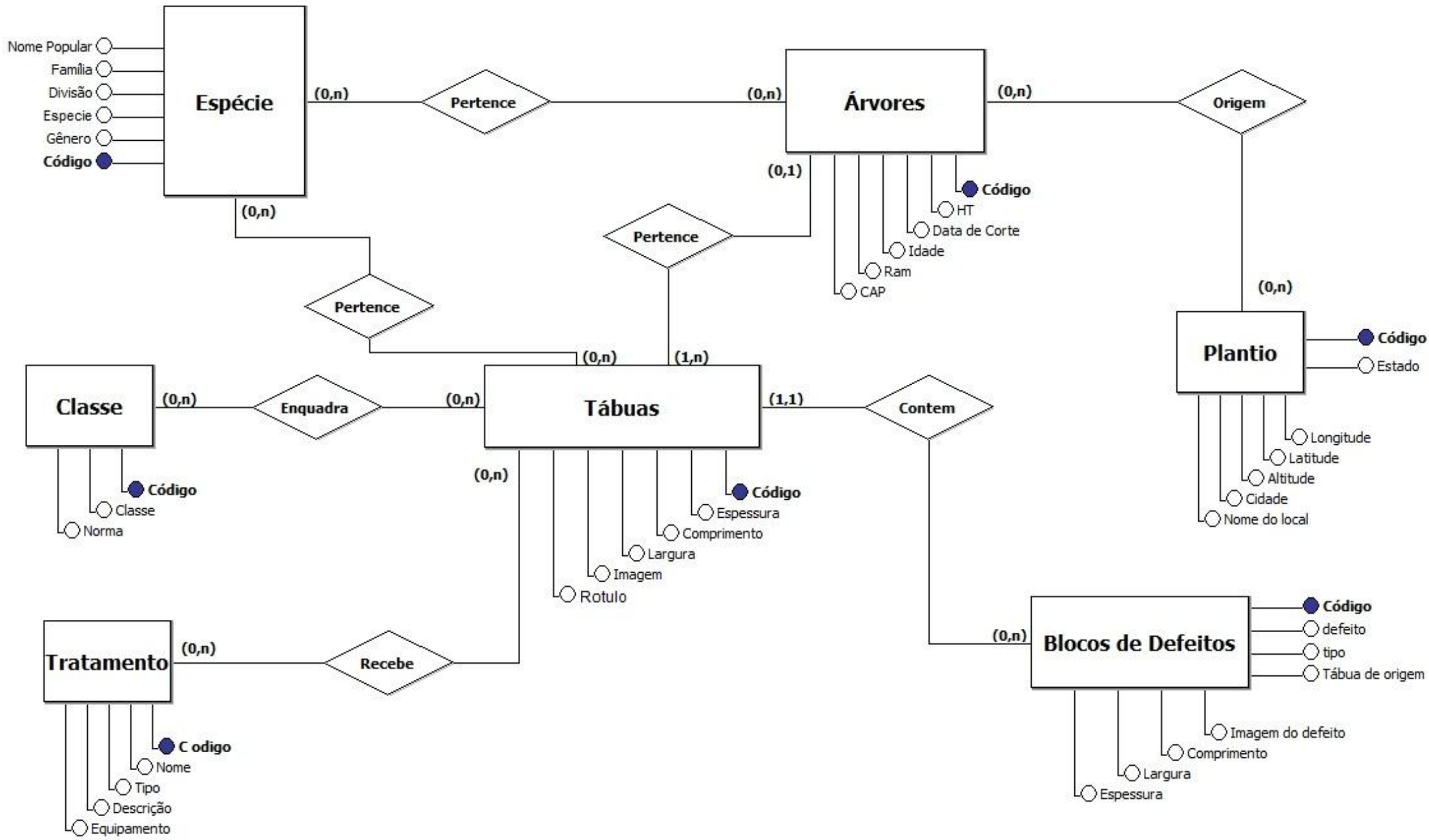

Figura 25 - Modelo conceitual do banco de dados de tábuas diagramado no software BrModelo 


\subsubsection{Modelo lógico, diagrama entidade e relacionamento}

O modelo entidade e relacionamento, cujo resultado é um diagrama chamado de Diagrama Entidade e Relacionamento (DER), em contrapartida ao modelo conceitual, é um documento de conteúdo técnico que exige um conhecimento básico sobre as teorias de bancos de dados para ser entendido. É um documento primordial e contribui muito na construção e reconstrução de um banco de dados.

O MySQL Workbench, software utilizado na construção desse modelo, se mostrou adequado e suficiente. Construiu de forma relativamente fácil, em comparação a outras ferramentas existentes no mercado, o DER.

A Figura 26 apresenta o diagrama de entidade e relacionamento do banco de dados de imagens digitais de tatuas de Pinus.

O diagrama construído representa as entidades como elas foram implementadas no banco de dados, com seus nomes reais e seus atributos definidos, seguindo-se as regras gerais para construção de bancos de dados. Uma diferença básica é a nomenclatura, que pode ser percebida comparando-se o nome dos atributos no modelo conceitual apresentado anteriormente e os nomes dos mesmos atributos no DER. A apresentação gráfica também muda bastante, além do modelo apresentar outras características como índices (indexes), chaves primária e estrangeira (primary e fk_index). São apresentados não só os atributos, que recebem o nome de campos do banco de dados, mas também o tipo de dados que cada campo armazenará. Para exemplificar tem-se o campo "descrição", que é um campo que armazena dados textuais e recebeu o tipo VARCHAR enquanto os campos "largura" e "espessura", que armazenam dados numéricos, foram definidos como DOUBLE, que define, em banco de dados, o tipo de dados numéricos com aceitação de casas decimais.

As relações entre as entidades também são representadas, porém de forma menos clara do que no modelo conceitual, mas ainda de fácil entendimento por um técnico da área. Ou seja, o DER gerado pode ser usado por um técnico em banco de dados para recriar as tabelas e os relacionamentos entre elas de modo a reconstruir o banco de dados de imagens digitais de tábuas de Pinus, se necessário. 


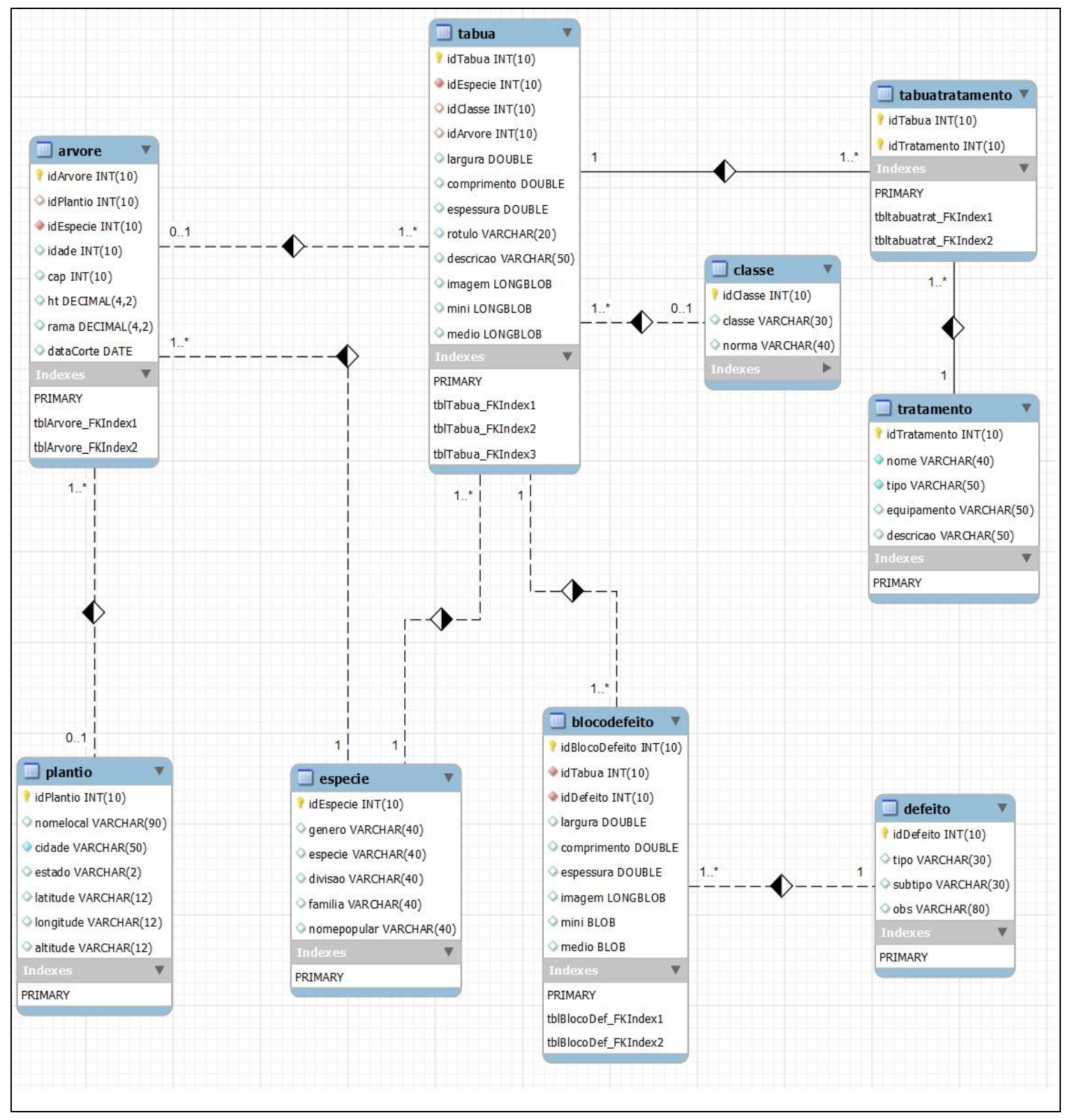

Figura 26 - Diagrama de entidade e relacionamento (DER) construído no software MySQL Workbench.

\subsubsection{Estruturas das tabelas construídas}

Para cada entidade modelada anteriormente, foi construída uma tabela no banco de dados, as quais devem seguir exatamente o que foi determinado no diagrama entidade e relacionamento. Ou seja, a tabela é o produto físico da modelagem, na qual todas as especificações definidas na fase do projeto são aplicadas e implementadas.

Utilizando o SGBD MySQL e digitando os comandos da 
linguagem de banco de dados SQL, constantes no modelo físico, foram construídas as tabelas e estabelecidos os relacionamentos diretos e indiretos entre cada uma delas. A construção das tabelas ocorreu por meio da definição de cada campo necessário para cada tabela, dos tipos de dados que esses campos recebem, do tamanho, ou seja, a quantidade máxima de dígitos numéricos ou textuais que os campos armazenariam, além das restrições impostas pelas regras de negócios estabelecidas ao se estudar o problema. Tais restrições são: campos que não podem ser nulos "NOT NULL", ou seja, não podem ficar sem valor definido; campos que não podem ser duplicados "PRIMARY KEY", representado pela chave amarela ao lado do nome do campo, representada na interface gráfica do MySQL Querybrowser, e que garantem a unicidade dos dados. E os campos de uma tabela que serão associados a campos de outras tabelas, garantem a integridade referencial no banco de dados. Exemplos de campos que fazem uso dessas restrições são os campos "IdTabua", "IdDefeito", "IdBlocodeDefeito" e todos os outros campos que seguem esta nomenclatura começada com as letras Id, que significam identificador, o que não é uma regra definida para bancos de dados, porém é visto como boa prática na implementação dos mesmos.

Percebeu-se, na estrutura das tabelas construídas, que os campos que receberam dados numéricos foram definidos como INTEGER ou DOUBLE e que os campos que receberam dados textuais foram definidos como VARCHAR seguido do numero de caracteres (entre parênteses) que o campo pode armazenar. Os campos que receberam as imagens digitais das tábuas foram definidos como variações do tipo de dados BLOB, que significa Binary Long Object, ou objeto binário longo.

As Figuras 27 a 34 ilustram as tabelas construídas no MySQL, que receberam os dados. Como as figuras apresentam resultados semelhantes aos das figuras do capítulo sobre dicionário de dados que detalha a estrutura das tabelas, a explicação das mesmas se dará no referido capítulo. 


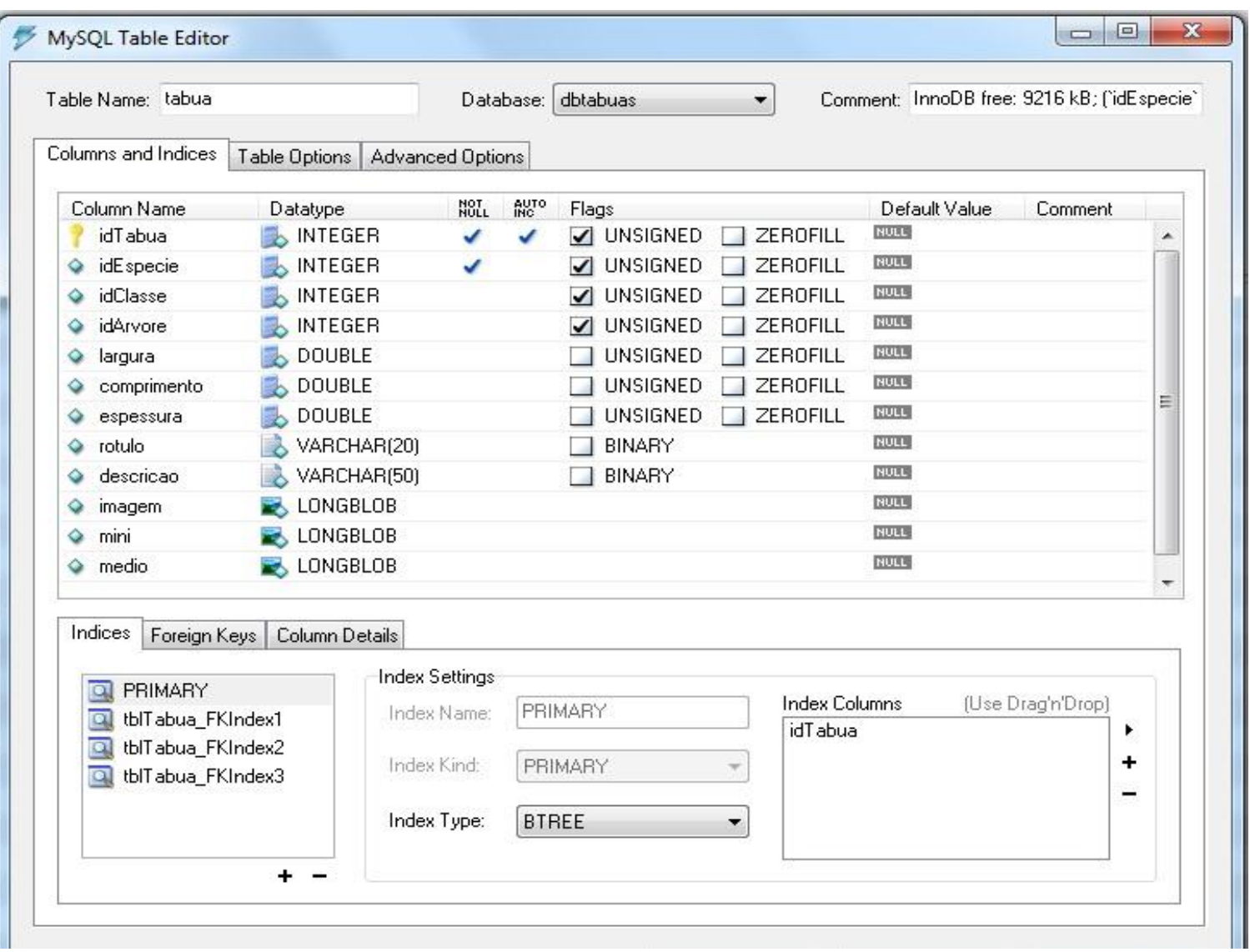

Figura 27 - Estrutura da tabela que receberá metadados e imagens das tábuas

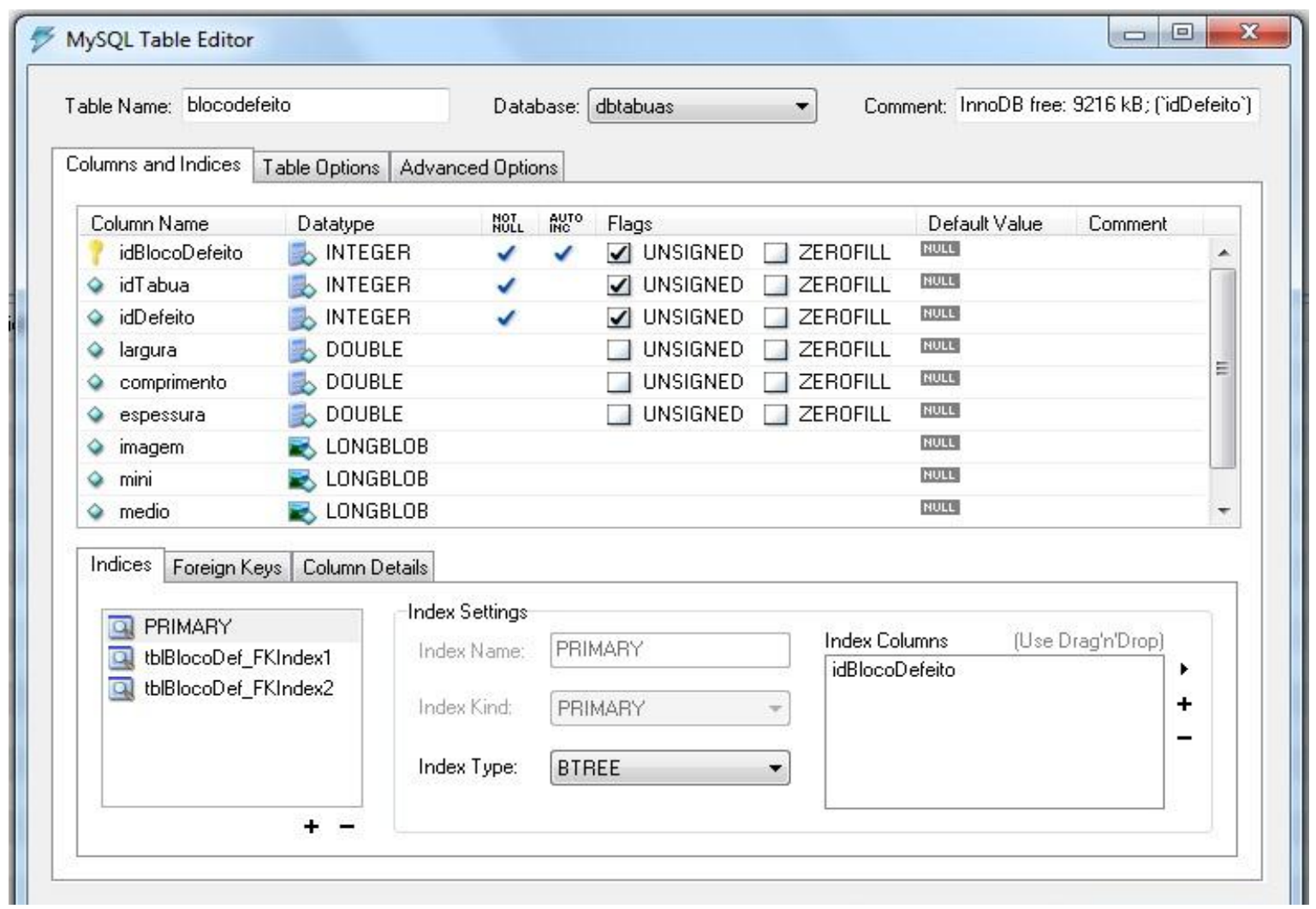

Figura 28 - Estrutura da tabela que receberá metadados e imagens dos blocos de defeito 


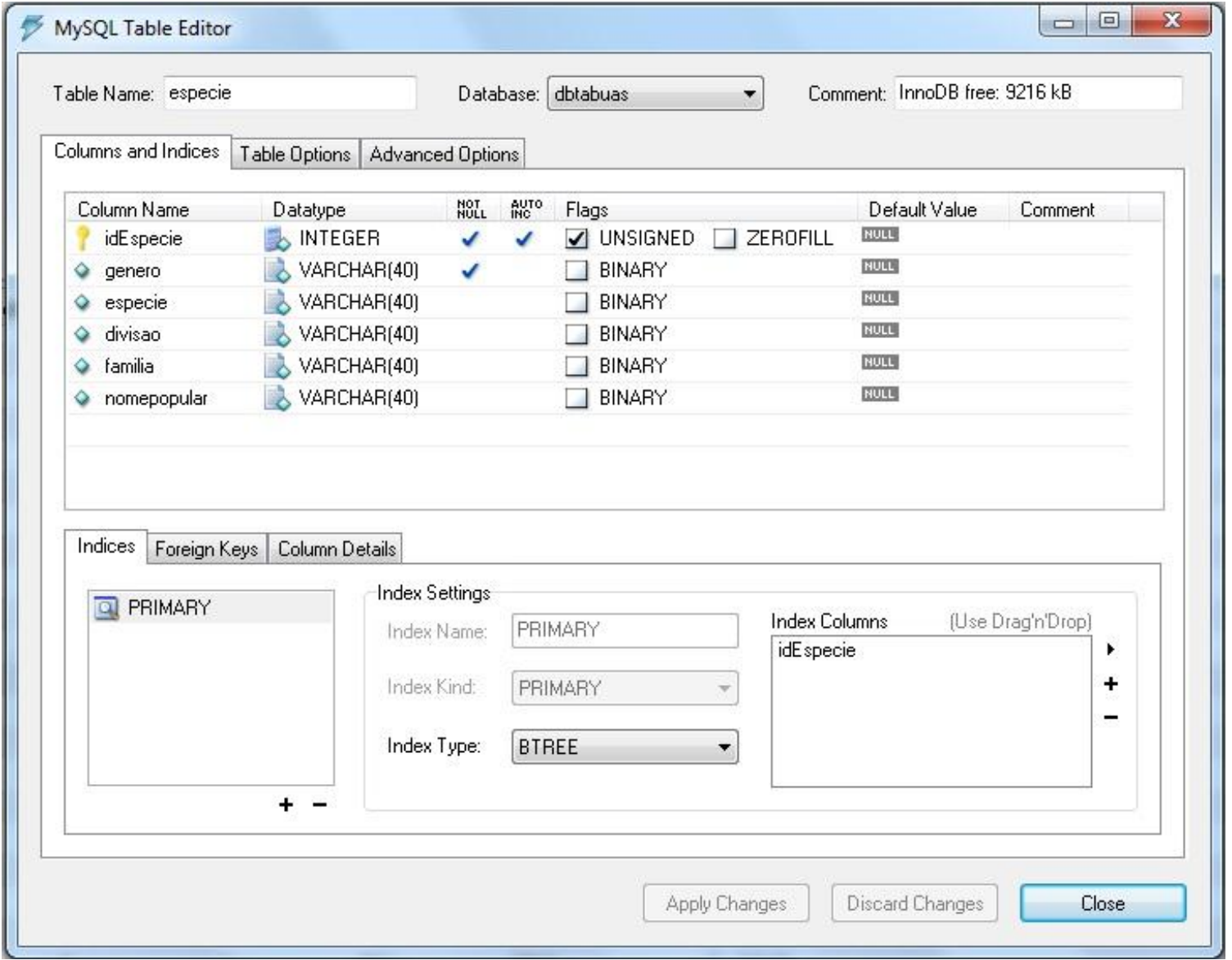

Figura 29 - Estrutura da tabela que receberá dados sobre as espécies

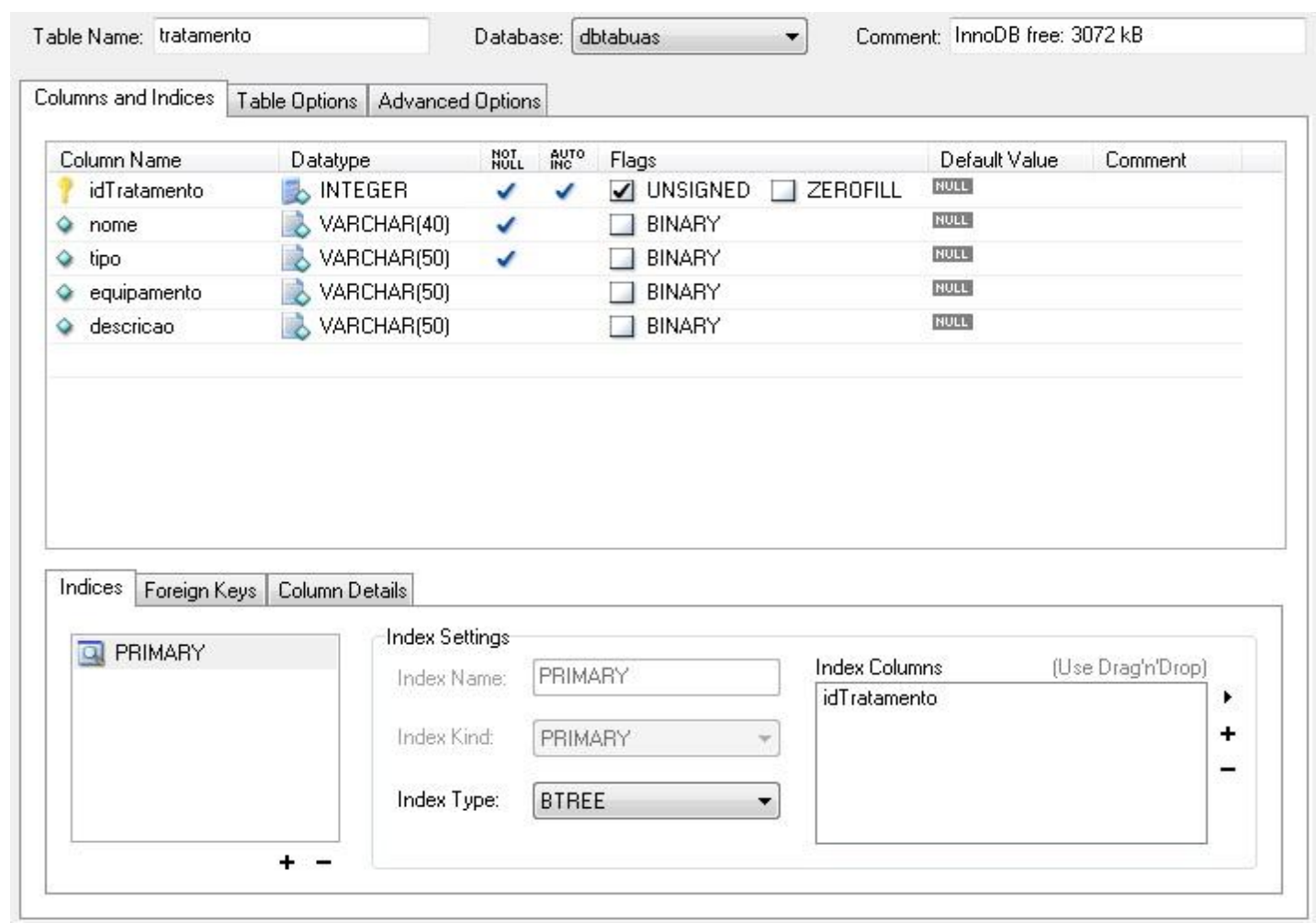

Figura 30 - Estrutura da tabela que receberá dados sobre tratamentos aplicados 


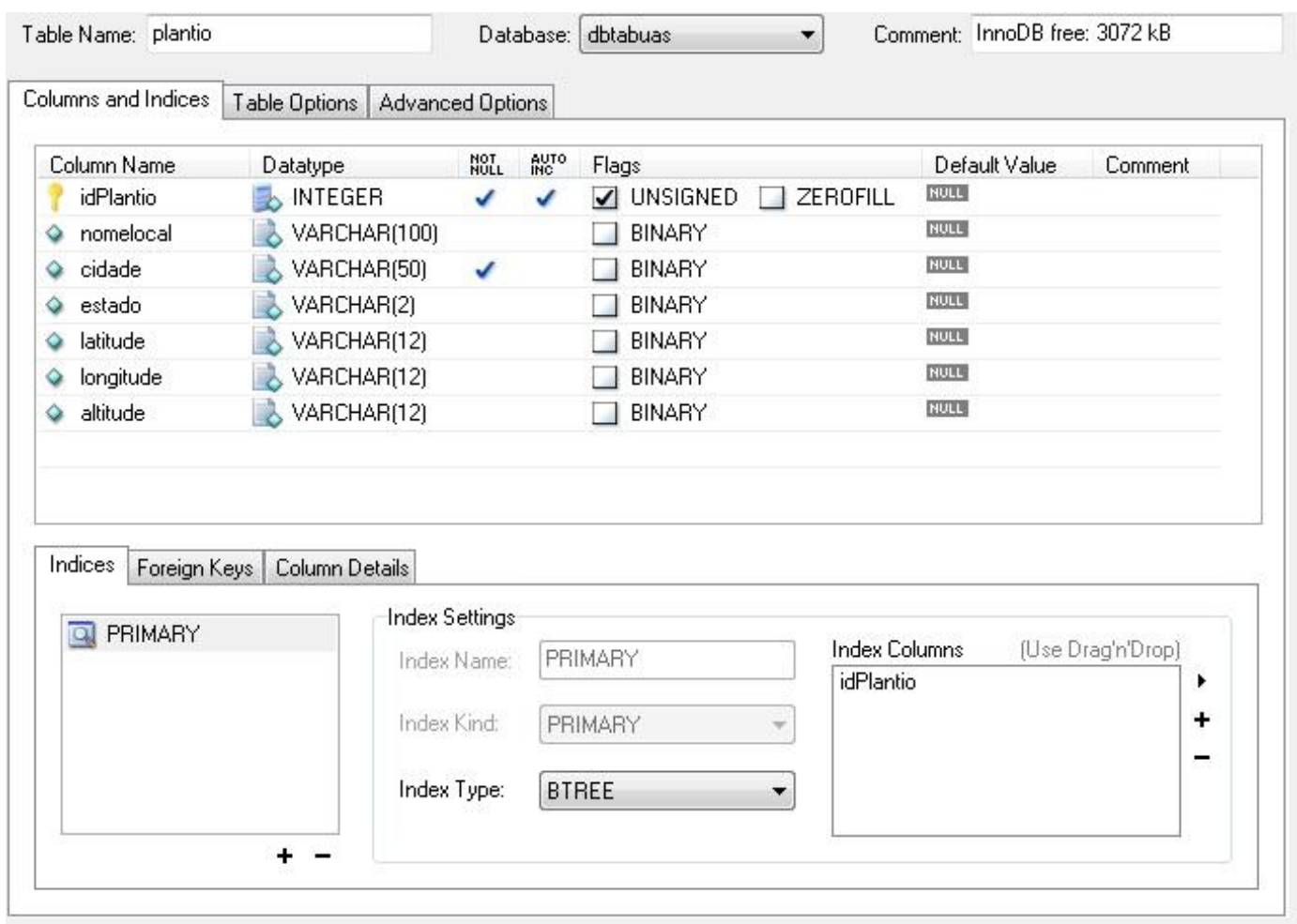

Figura 31 - Estrutura da tabela que receberá dados sobre a região de plantio da árvore

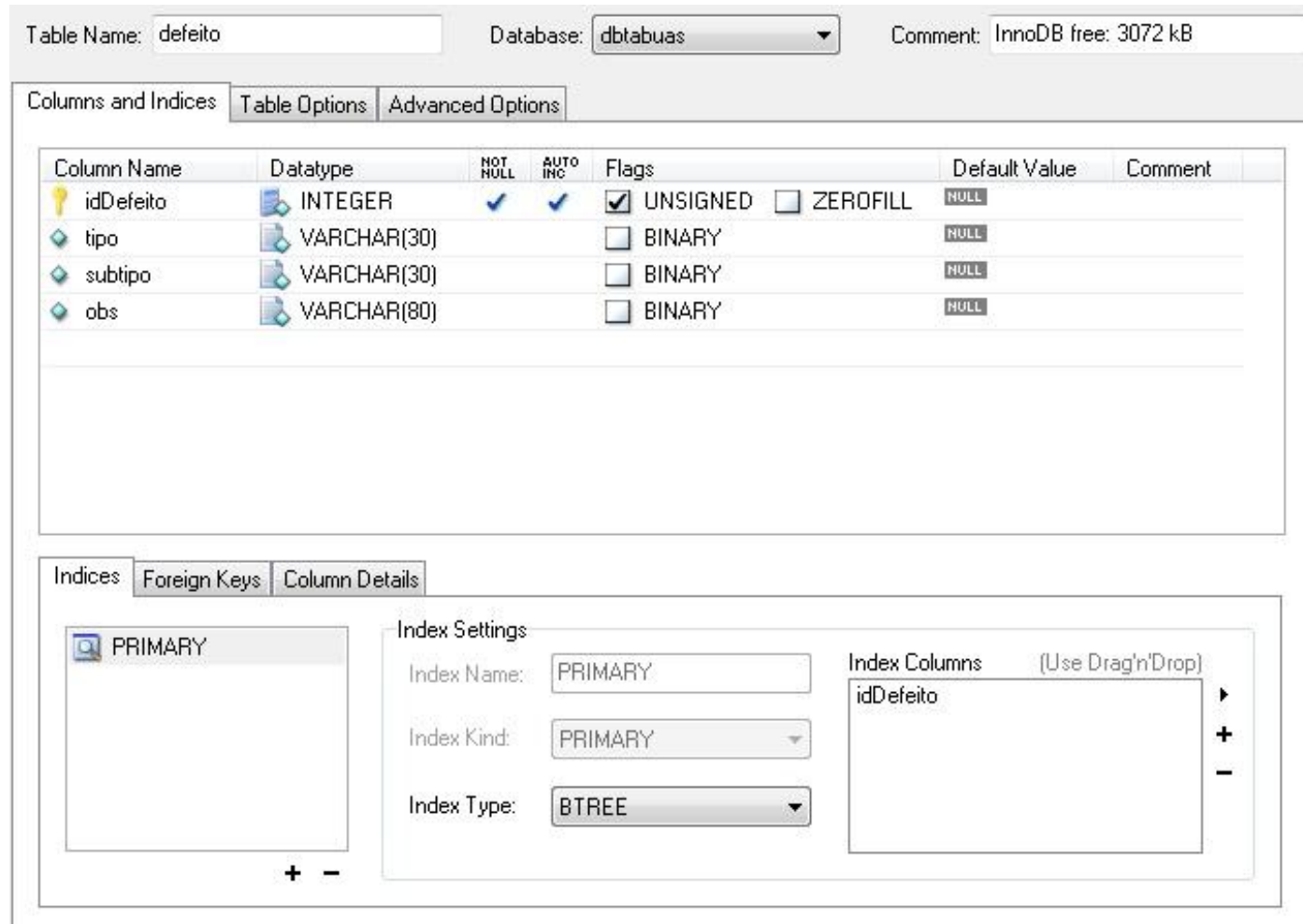

Figura 32 - Estrutura da tabela que armazenara defeitos catalogados na norma 


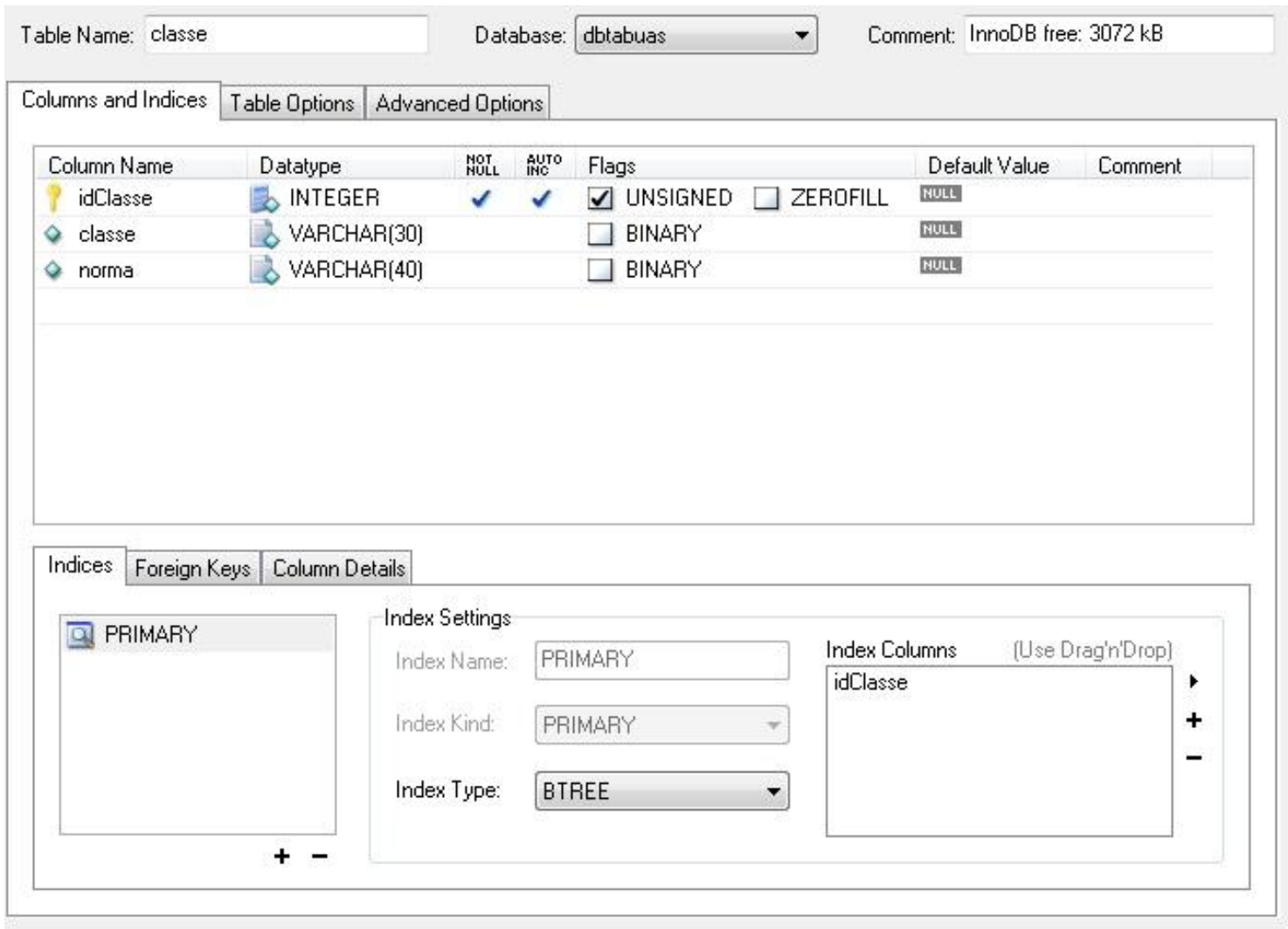

Figura 33 - Estrutura da tabela que armazenara as classes catalogadas na norma

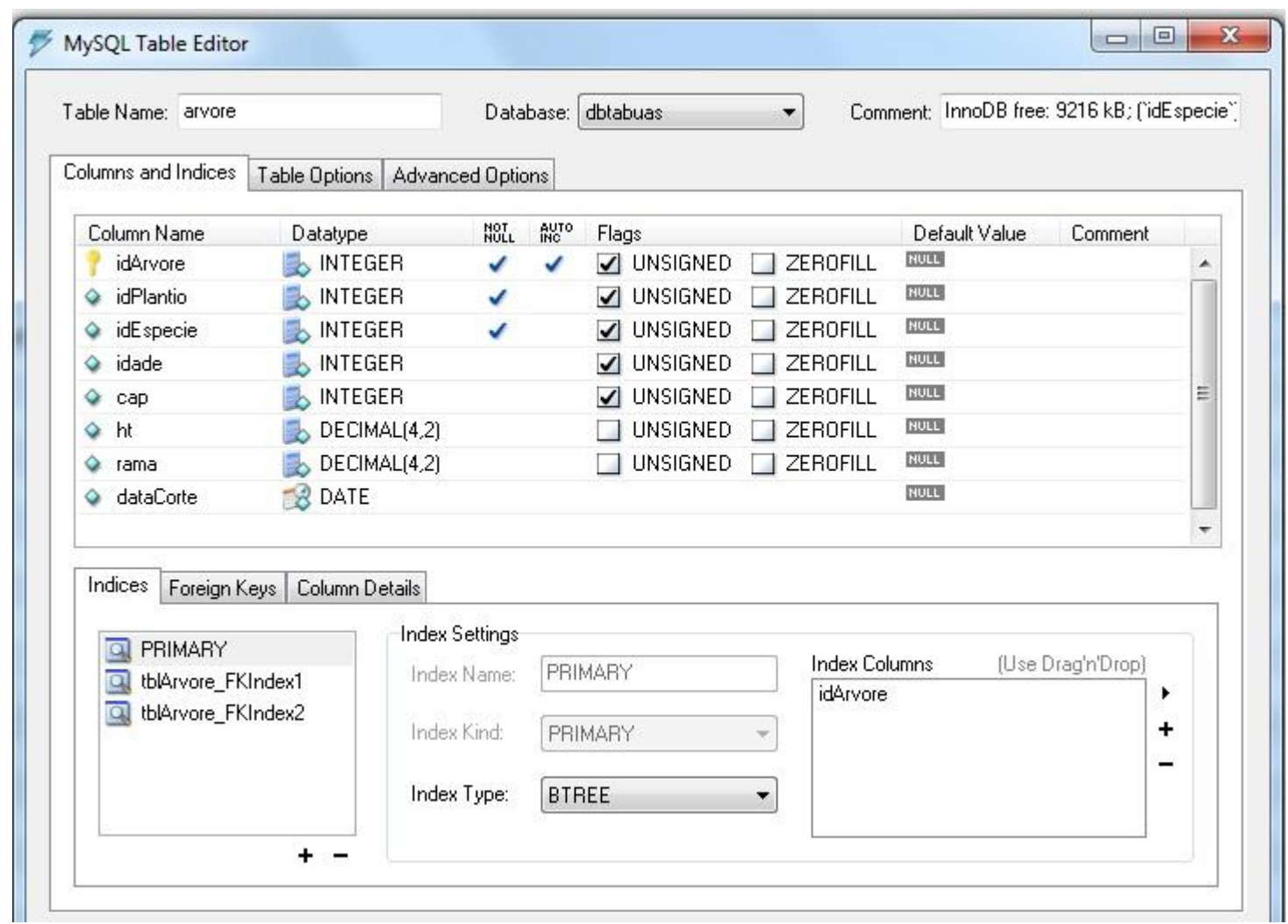

Figura 34 - Estrutura da tabela que armazenara dados sobre as árvores de origem das tábuas 


\subsubsection{Modelo físico}

Aplicando-se uma ferramenta do MySQL conhecida como "dump", foi gerado um documento textual contendo todos os comandos SQL utilizados para construir as tabelas, definir seus atributos e estabelecer as relações de referência entre as tabelas. Outra maneira é, ao digitar cada comando no SGDB, copiar tais comandos e colando em um software de edição de textos. Esse segundo método se mostra mais demorado, podendo gerar erros pelo fato do processo "copiar e colar" ser totalmente manual. O método "dump" foi o escolhido e empregado nesse trabalho, por ser mais confiável e gerar um documento livre de erros. A Figura 35 apresenta o modelo físico gerado pelo processo de "dump", a partir da digitação adequada do comando mysqldump do SGBD MySQL, na linha de comando do sistema operacional (prompt do DOS).

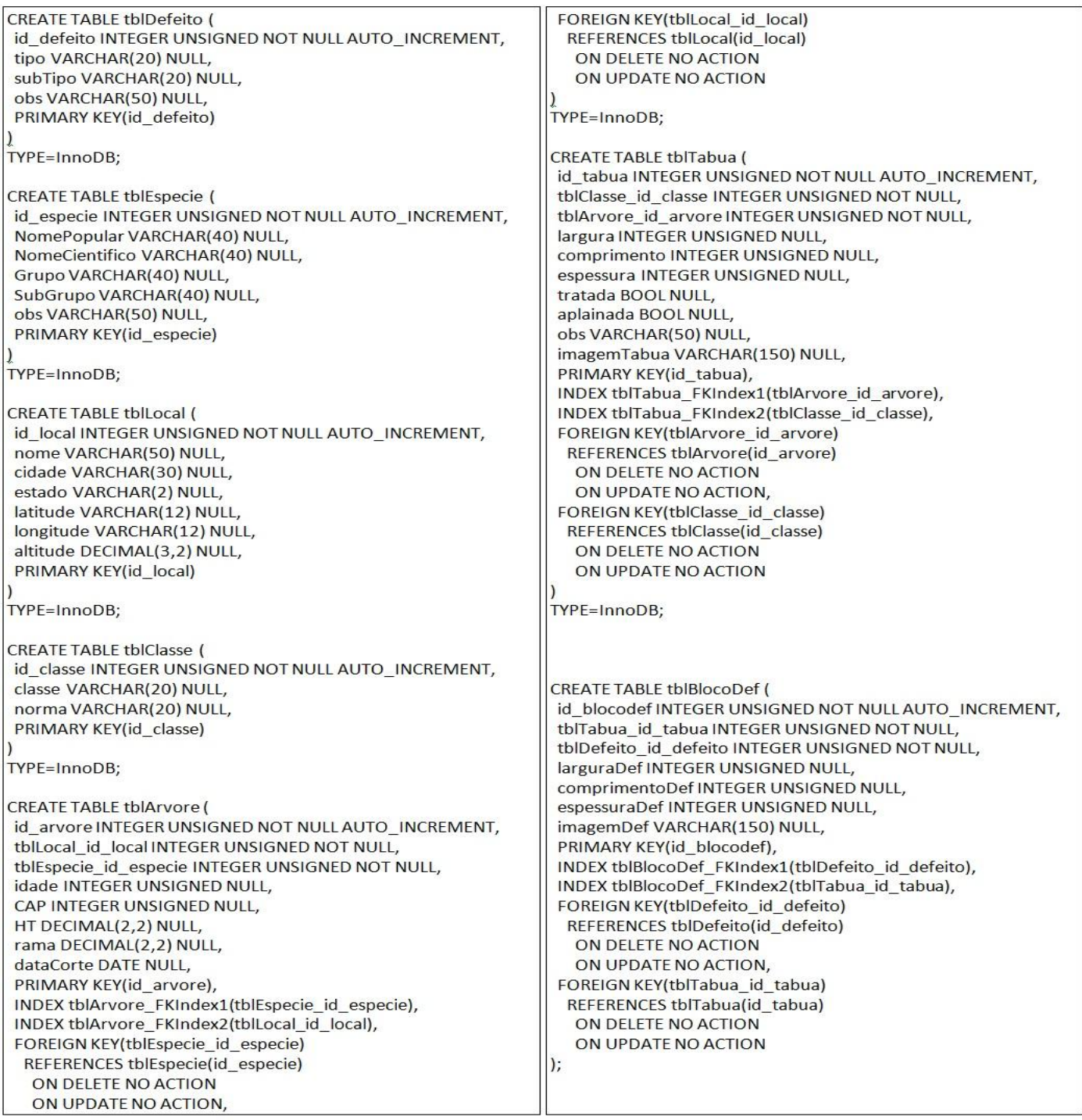

Figura 35 - Modelo físico do banco de dados de tábuas gerado pelo MySQLDump. 
Os comandos SQL constantes desse documento, se executados linha a linha e na ordem em que se encontram no mesmo (em sequência de script), geram o banco de dados construído de forma idêntica, se aplicado no mesmo SGBD no qual foi criado.

\subsubsection{Dicionário de dados}

Neste documento observam-se outros detalhes, que não constam na estrutura das tabelas já apresentadas. Pode-se notar a coluna de descrição dos campos preenchida e uma coluna com exemplos de dados que podem ser armazenado naquele determinado campo. Essas duas colunas esclarecem, juntas, quais tipos de informações os campos foram preparados para receber. As demais colunas detalham o nome do campo no banco de dados, o tipo de dados que o campo aceita, o tamanho do campo e suas restrições, tais como não poder ser um campo com valor nulo ou não poder receber valores repetidos no campo. Quando observa-se nas restrições o termo "Estrangeira", significa que aquele campo tem uma relação de referência com um campo de outra tabela. As Figuras 36 a 39 ilustram as telas da planilha construída para descrever os dados gerados a partir da extração e análise de requisitos para o banco de dados em questão. Esse documento se mostrou importante para o processo de construção do banco de dados, pois demonstra a estrutura previamente definida para cada tabela.

A Figura 36 detalha, especificamente, as tabelas de defeito, espécie e classe. Essas tabelas foram construídas no banco de dados para receberem dados auxiliares às tabelas principais, que armazenam as imagens das tábuas e dos blocos de defeitos. A tabela "defeitos" recebe a lista de defeitos catalogados na norma ABNT específica. A tabela de "espécies" armazena dados básicos das espécies que possuem imagens cadastradas no banco de dados.

A tabela de classes recebeu as classes definidas na norma específica da ABNT. As tabelas auxiliares foram preenchidas antes do povoamento das tabelas de imagens de tábuas e de blocos de defeitos. Outras tabelas auxiliares estão representadas nas Figuras 37 e 38. As tabelas plantio, árvore e tratamento também recebem dados que auxiliam as tabelas principais de imagens e são relacionadas às mesmas. A tabela "tratamento" recebeu dados de tratamentos comuns aplicados em tábuas de madeira serrada, tais como secagem, aplainamento, refilamento e preservante. As árvores, das quais foram desdobradas tábuas, foram catalogadas na tabela "árvores" e os dados de sua 
localização, armazenados na tabela "plantio". Optou-se por duas tabelas distintas, pois, em uma colaboração de imagens de tábuas ou de imagens de blocos de defeitos por fontes externas (outras instituições que por ventura possa colaborar enviando imagens de tábuas com defeitos interessantes ou raros) pode-se ter apenas os dados sobre a localização do plantio de onde a árvore foi extraída e não os dados da árvore em si, uma vez que se tem apenas a tábua e poucos dados de sua origem. Isso prejudicaria a estrutura do banco de dados e essa técnica se fez necessária.

A Figura 39 (e também parte da Figura 38) detalham as tabelas principais do banco de dados, que são assim chamadas por armazenarem as imagens das tábuas e dos blocos de defeitos, as quais são o foco principal deste trabalho. Pode-se observar na tabela de blocos de defeitos que os campos "IdTabua" e "IdDefeito" são campos numéricos que recebem valores referentes ao código de identificação de tábuas específicas e defeitos específicos, já armazenados nas tabelas de origem. Essa técnica garante que a imagem do bloco de defeito seja associada ao registro da tábua da qual o mesmo foi extraído e ainda que se escolha um defeito que já tenha sido armazenado na tabela de defeitos.

\subsubsection{Implementação do banco de dados}

A Figura 40 apresenta a tela principal da interface gráfica do MySQL Workbench, desenvolvida para facilitar a operação do sistema de gerenciamento de banco de dados MySQL. Apresentando o banco de dados de imagens de tábuas sendo desenvolvido. Percebeu-se, nessa figura, que o MySQL Workbench é uma ferramenta que interagiu com diversos componentes do projeto. Na porção superior direita da imagem chamada de Diagram visualiza-se parte do DER gerado para o banco de dados em questão. $\mathrm{Na}$ porção inferior direita da figura tem-se a estrutura da tabela de tábuas. No lado esquerdo central da imagem, pode-se visualizar uma estrutura que elenca as tabelas construídas para o projeto.

Com o banco de dados pronto para receber os dados e imagens, seguiu-se a fase de testes, onde foram inseridos os dados e verificados alguns aspectos de funcionamento e corrigindo possíveis equívocos de modelagem e implementação. Porém, o processo de modelagem serve justamente para minimizar tais erros. Sendo os testes bem sucedidos, seguiu-se o povoamento do banco de dados com os dados reais, finalizando o processo de desenvolvimento do banco de dados. 


\begin{tabular}{|c|c|c|c|c|c|}
\hline \\
\hline \multicolumn{6}{|c|}{$\begin{array}{l}\text { DEFEITOS } \\
\begin{array}{|l|l}\text { Campo } & \text { Tipo Dados }\end{array}\end{array}$} \\
\hline idDefeito & \begin{tabular}{|c|c} 
& Tipo Dados \\
& INTEGER
\end{tabular} & UNSIGNED NOT NULL AUTO_INCREMENT, & Primaria & Código do defeito gerado automaticamente & \\
\hline tipo & $\operatorname{VARCHAR}(30)$ & NULL, & & Especifica o tipo principal segundo a norma & nó, medula, furo, etc \\
\hline subtipo & $\operatorname{VARCHAR}(30)$ & NULL, & & Especificação do defeito & $\begin{array}{l}\text { vazado, cariado, inseto } \\
\text { inativo }\end{array}$ \\
\hline
\end{tabular}

\begin{tabular}{|l|c|c|l|l|}
\hline ESPECIE & Tipo Dados & Restrições & Chave & Descrição \\
\hline Campo & INTEGER & UNSIGNED NOT NULL AUTO_INCREMENT, & Primaria & Código do defeito gerado automaticamente \\
\hline idEspecie & VARCHAR(40) & NULL, & $\begin{array}{l}\text { Gênero na qual se enquadra a árvore da } \\
\text { espécie }\end{array}$ & $\begin{array}{l}\text { Espécie na qual se enquadra a árvore do } \\
\text { gênero }\end{array}$ \\
\hline especie & VARCHAR(40) & NOT NULL, & $\begin{array}{l}\text { Divisão na qual se enquadra a árvore da } \\
\text { espécie }\end{array}$ \\
\hline divisao & VARCHAR(40) & NULL, & $\begin{array}{l}\text { Família na qual se enquadra a árvore da } \\
\text { espécie }\end{array}$ \\
\hline familia & VARCHAR(40) & NULL, & Nome popular da espécie \\
\hline nomepopular & VARCHAR(80) & NULL, & & Pinaceae \\
\hline
\end{tabular}

\begin{tabular}{|l|c|l|l|l|l|}
\hline CLASSE & Tipo Dados & Restrições & Chave & Descrição \\
\hline Campo & INTEGER & UNSIGNED NOT NULL AUTO_INCREMENT, & Primaria & Código da classe gerado automaticamente & \\
\hline idClasse & VARCHAR(30) & NOT NULL, & & $\begin{array}{l}\text { Classe na qual a tábua se enquadrou após } \\
\text { classificação }\end{array}$ & Super, Terceira classe \\
\hline classe & VARCHAR(40) & NULL, & & Norma base para classificação \\
\hline norma & & NBR 11700 \\
\hline
\end{tabular}

Figura 36- Dicionário de dados com descrição das tabelas de defeito, espécie e tábua. 


\begin{tabular}{|c|c|c|c|c|c|}
\hline \multicolumn{6}{|l|}{ PLANTIO } \\
\hline Campo & Tipo Dados & Restrições & Chave & Descrição & Exemplo \\
\hline idPlantio & INTEGER & UNSIGNED NOT NULL AUTO_INCREMENT, & Primaria & Código do defeito gerado automaticamente & \\
\hline nomelocal & $\operatorname{VARCHAR}(100)$ & NULL, & & $\begin{array}{l}\text { Nome da instituição, fazenda, região de } \\
\text { plantio }\end{array}$ & $\begin{array}{l}\text { Horto Manduri, Fazenda } \\
\text { Lageado }\end{array}$ \\
\hline cidade & VARCHAR(50) & NOT NULL, & & Cidade do plantio & \\
\hline estado & VARCHAR(2) & NULL, & & Estado & \\
\hline latitude & VARCHAR(12) & NULL, & & $\begin{array}{l}\text { Latitude do talhão, se possivel, senão do } \\
\text { plantio }\end{array}$ & \\
\hline longitude & VARCHAR(12) & NULL, & & $\begin{array}{l}\text { Longitude do talhão, se possivel, senão do } \\
\text { plantio }\end{array}$ & \\
\hline altitude & VARCHAR(12) & NULL, & & $\begin{array}{l}\text { Altitude do talhão, se possivel, senão do } \\
\text { plantio }\end{array}$ & \\
\hline
\end{tabular}

\begin{tabular}{|l|c|c|l|l|}
\hline ARVORE & Tipo Dados & Restrições & Chave & Descrição \\
\hline Campo & INTEGER & UNSIGNED NOT NULL AUTO_INCREMENT, & Primaria & Código do defeito gerado automaticamente \\
\hline idPlantio & INTEGER & UNSIGNED NULL, & Estrangeira & $\begin{array}{l}\text { Código do plantio cadastrado de onde a } \\
\text { árvore foi retirada }\end{array}$ \\
\hline idEspecie & INTEGER & UNSIGNED NOT NULL, & Estrangeira & $\begin{array}{l}\text { Código da espécie da árvore previamente } \\
\text { cadastrada }\end{array}$ \\
\hline idade & INTEGER & UNSIGNED NULL, & Idade exata ou aproximada \\
\hline cap & INTEGER & UNSIGNED NULL, & $\begin{array}{l}\text { Circunferência da árvore na altura do } \\
\text { peito,em centímetros, a 1,30m do solo }\end{array}$ \\
\hline ht & DECIMAL(2,2) & NULL, & Altura total da árvore em metros \\
\hline rama & DECIMAL(2,2) & NULL, & Altura da primeira rama, em relação ao solo & \\
\hline datacorte & DATE & NULL, & & Data de derrubada da árvore \\
\hline
\end{tabular}

Figura 37 - Dicionário de dados com descrição das tabelas de plantio e árvore 


\begin{tabular}{|l|c|c|l|l|}
\hline TRATAMENTO & Tipo Dados & Restrições & Chave & Descrição \\
\hline Campo & INTEGER & UNSIGNED NOT NULL AUTO_INCREMENT, & Primaria & Código do defeito gerado automaticamente \\
\hline nome & VARCHAR(40) & NOT NULL, & Nome comum do tratamento aplicado \\
\hline tipo & VARCHAR(50) & NOT NULL, & $\begin{array}{l}\text { Eplainamento, refilamento, } \\
\text { preservação }\end{array}$ \\
\hline equipamento & VARCHAR(50) & NULL, & Face, borda, CBA \\
\hline descricao & VARCHAR(50) & NULL, & $\begin{array}{l}\text { Plaina industrial, plaina } \\
\text { manual, autoclave }\end{array}$ \\
\hline
\end{tabular}

\begin{tabular}{|l|c|c|l|l|}
\hline BLOCODEFEITO & Tipo Dados & Restrições & Chave & Descrição \\
\hline Campo & INTEGER & UNSIGNED NOT NULL AUTO_INCREMENT, & Primaria & Código do defeito gerado automaticamente \\
\hline IdBlocoDefeito & INTEGER & UNSIGNED NOT NULL, & Estrangeira & Código da tábua na qual se encontra o defeito \\
\hline idTabua & INTEGER & UNSIGNED NOT NULL, & Estrangeira & $\begin{array}{l}\text { Código do tipo de defeito catalogado na } \\
\text { tabela defeitos }\end{array}$ \\
\hline idDefeito & DOUBLE & NULL, & & Largura do defeito, em centímetros \\
\hline largura & DOUBLE & NULL, & Comprimento do defeito, centímetros \\
\hline comprimento & DOUBLE & NULL, & Espessura do defeito, em centímetros \\
\hline espessura & LONGBLOB, & & & Imagem original do defeito, .JPG \\
\hline imagem & BLOB, & Imagem do defeito em miniatura, .JPG & Imagem mediana para pré visualização, site, \\
\hline mini & BLOB, & $\begin{array}{l}\text { Aplicado de grande } \\
\text { extensão, medula }\end{array}$ \\
\hline medio & & & \\
\hline
\end{tabular}

Figura 38 - Dicionário de dados com descrição das tabelas de tratamento e bloco de defeito 


\begin{tabular}{|c|c|c|c|c|c|}
\hline \multicolumn{6}{|l|}{ TABUA } \\
\hline Campo & Tipo Dados & Restrições & Chave & Descrição & Exemplo \\
\hline idTabua & INTEGER & UNSIGNED NOT NULL AUTO_INCREMENT, & Primaria & Código do defeito gerado automaticamente & \\
\hline idEspecie & INTEGER & UNSIGNED NOT NULL, & Estrangeira & $\begin{array}{l}\text { Código da espécie da árvore previamente } \\
\text { cadastrada }\end{array}$ & \\
\hline idClasse & INTEGER & UNSIGNED, & Estrangeira & $\begin{array}{l}\text { Código da espécie da árvore previamente } \\
\text { cadastrada }\end{array}$ & \\
\hline idTratamento & INTEGER & UNSIGNED, & Estrangeira & $\begin{array}{l}\text { Código do tratamento recebido pela tábua, já } \\
\text { cadastrado }\end{array}$ & \\
\hline idArvore & INTEGER & UNSIGNED, & Estrangeira & $\begin{array}{l}\text { Código da árvore da qual a tábua foi } \\
\text { desdobrada }\end{array}$ & \\
\hline largura & DOUBLE & NULL, & & Largura da tábua, em centímetros & \\
\hline comprimento & DOUBLE & NULL, & & Comprimento da tábua, em centímetros & \\
\hline espessura & DOUBLE & NULL, & & Espessura da tábua, em centímetros & \\
\hline descricao & VARCHAR (50), & & & $\begin{array}{l}\text { Alguma observação pertinente sobre aspectos } \\
\text { tábua }\end{array}$ & \\
\hline imagem & LONGBLOB, & & & Imagem original em formato .JPG da tábua & \\
\hline $\operatorname{mini}$ & LONGBLOB, & & & Imagem miniatura .JPG da tábua para o site & \\
\hline media & LONGBLOB, & & & $\begin{array}{l}\text { Imagem mediana para pré visualização, site, } \\
\text {.JPG }\end{array}$ & \\
\hline
\end{tabular}

Figura 39 - Dicionário de dados - tabela de tábuas 


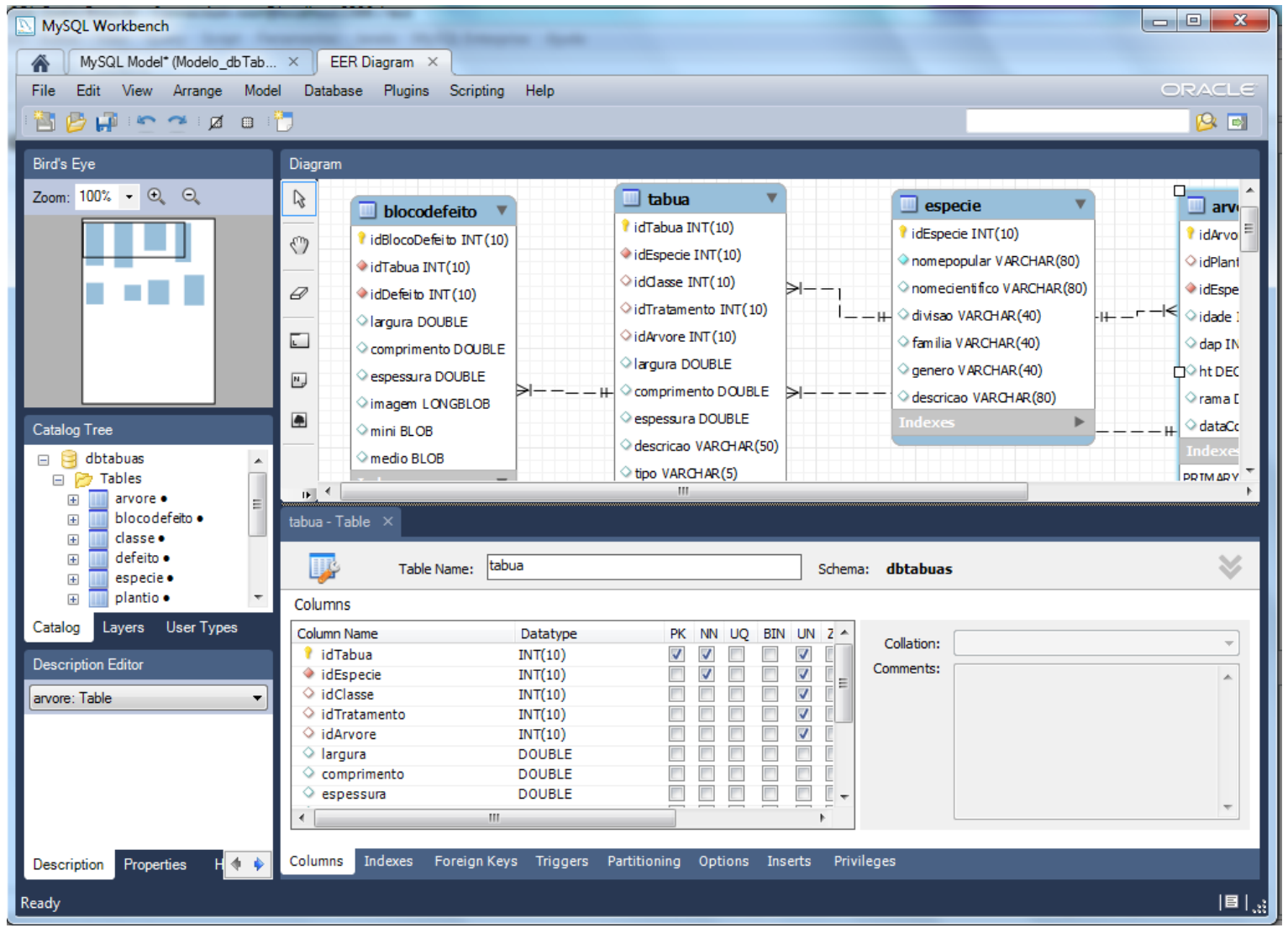

Figura 40 - Banco de dados sendo desenvolvido no MySQL Workbench

\subsection{Sistema web para acesso ao banco de dados}

A aplicação desenvolvida para acesso ao banco de dados é um software que funciona sobre a plataforma web. Sendo assim, a partir do momento que o sistema computacional for instalado em um computador que trabalhe como servidor da aplicação desenvolvida, basta o usuário ter conhecimento de sua existência e endereço e utilizar um computador com acesso à internet.

Tendo finalizado o desenvolvimento do sistema web, o banco de dados ficou totalmente integrado ao sistema, possibilitando o uso pleno de todos os seus recursos de manipulação na base de imagens.

Para o desenvolvimento do sistema computacional voltado para ambiente web, foi utilizada a plataforma Java, que inclui a linguagem de programação Java, o container de aplicações Glassfish e a máquina virtual Java (JVM).

Para o processo de desenvolvimento do programa propriamente dito, que consiste em codificar linha a linha os comandos da linguagem de programação escolhida, foi empregada a interface de desenvolvimento de software (IDE) Netbeans 
versão 7.2.1. Todas as ferramentas utilizadas neste processo foram escolhidos por oferecerem grande poder de desenvolvimento ao programador e são todos voltados especificamente para aplicações web, além de serem todos gratuitos.

Esse conjunto de ferramentas se mostrou eficiente e atingiu todos os resultados esperados, contribuindo para a implementação de uma aplicação, que apesar de trabalhar com imagens o que as torna naturalmente pesadas e de funcionamento custoso para o browser, se apresentou leve e de fácil manipulação, com retorno das imagens de forma relativamente ágil.

A Figura 41 apresenta a tela de desenvolvimento do sistema web no

Netbeans IDE 7.2.1.

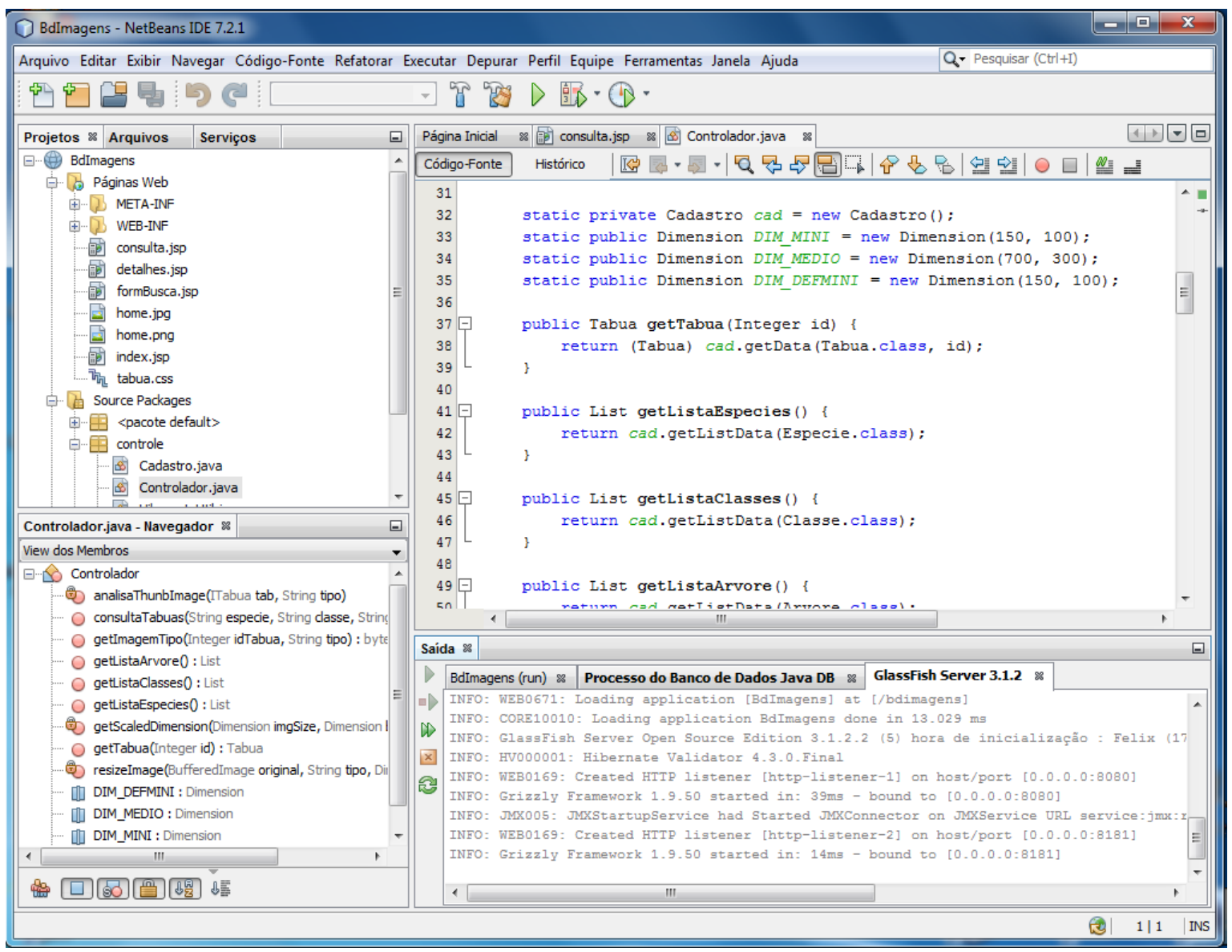

Figura 41 - Tela de processo de desenvolvimento do sistema web no ambiente de desenvolvimento de softwares Netbeans.

\subsubsection{Tela inicial do sistema}

Uma tela inicial foi criada com o objetivo de apresentar o sistema computacional, abordando seus criadores e razões de sua existência. Essa tela de 
apresentação segue o que é de costume em sites de internet e é conhecida como home ou página inicial do site.

A Figura 42 mostra a página inicial do sistema web conhecida como Home, que apresenta as boas vindas ao usuário e, geralmente, traz informações básicas sobre o site que está sendo acessado.

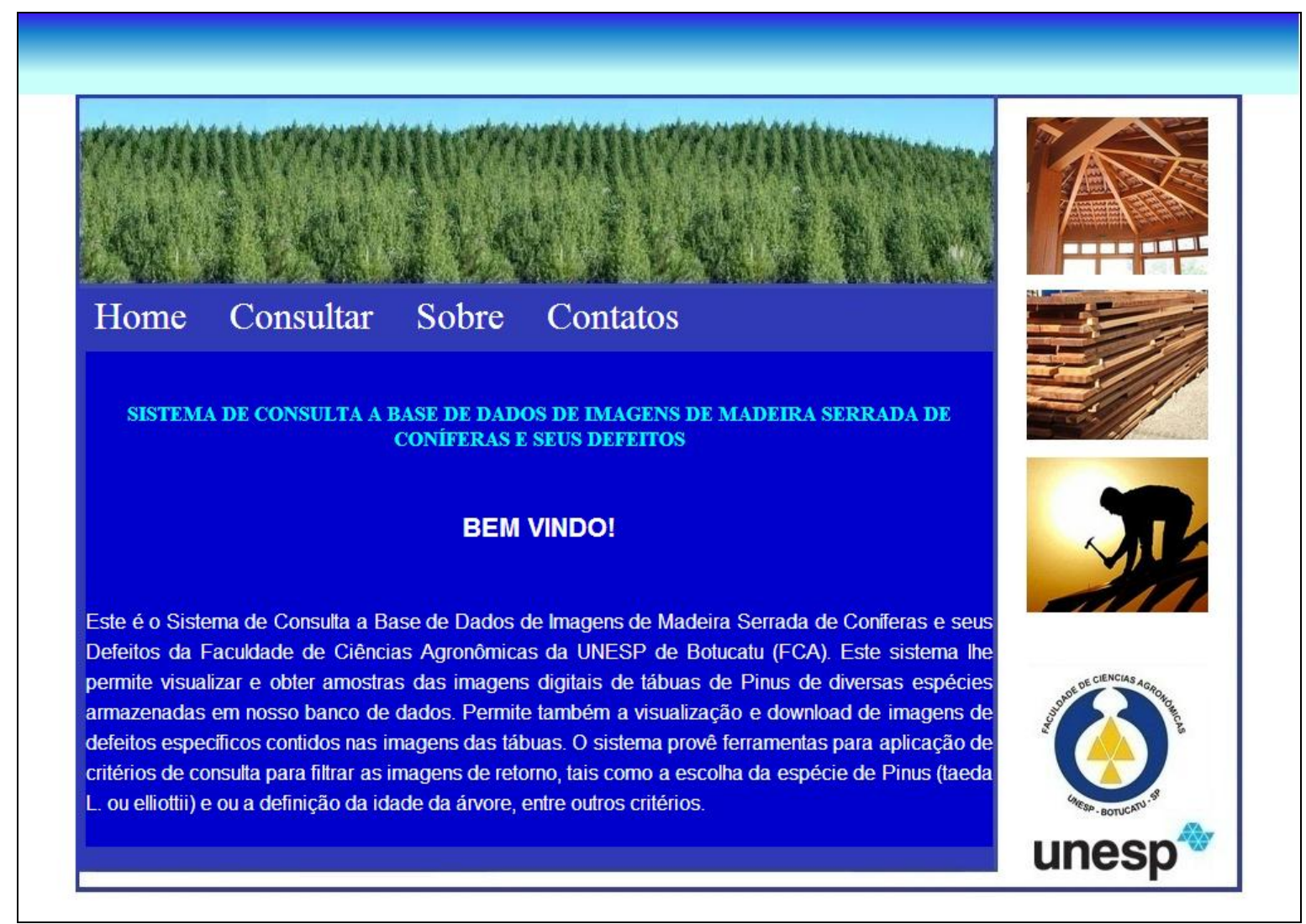

Figura 42 - Tela inicial do sistema web (home)

\subsubsection{Tela de consulta de imagens e metadados das tábuas}

$\mathrm{Na}$ Figura 43, ilustra-se a tela de consulta do sistema web, que apresenta uma interface de consulta na base de imagens e o resultado da pesquisa, com o retorno da imagem da tábua que apresenta maior relevância e consistência aos critérios de consulta. Também são apresentadas as imagens dos blocos de defeitos da tábua em questão, se os mesmos tiverem sidos armazenados.

No lado direito da tela de consulta são apresentadas miniaturas de todas as tábuas que satisfazem o critério de seleção estabelecido. Tais critérios são definidos por meio de seleção, clicando-se nas setas que constam nas caixas de opções que são localizadas na porção inferior da tela. Cada caixa de opções apresenta apenas os dados 
cadastrados e possíveis para consulta. Por exemplo, ao clicar na seta da caixa "Espécie" serão trazidas duas opções, Elliottii e Taeda L, pois só essas duas espécies foram catalogadas por conterem imagens de tábuas de tais espécies armazenadas no banco. A estrutura do banco de dados criado exige que, antes de armazenar uma imagem de tábua de determinada espécie, seja cadastrada a espécie em questão. O mesmo acontece com outros campos, tais como tipos de defeito, classe e tratamento, para cadastrar imagens que fazem referência a esses dados os mesmo devem ter sido previamente cadastrados.

Por fim, depois de estabelecer os critérios de consulta, basta clicar no botão buscar para se ter os resultados na tela. Caso não haja imagens que satisfaçam todos os critérios pode-se ir reduzindo a combinação até que se tenha retorno de alguma imagem relevante.

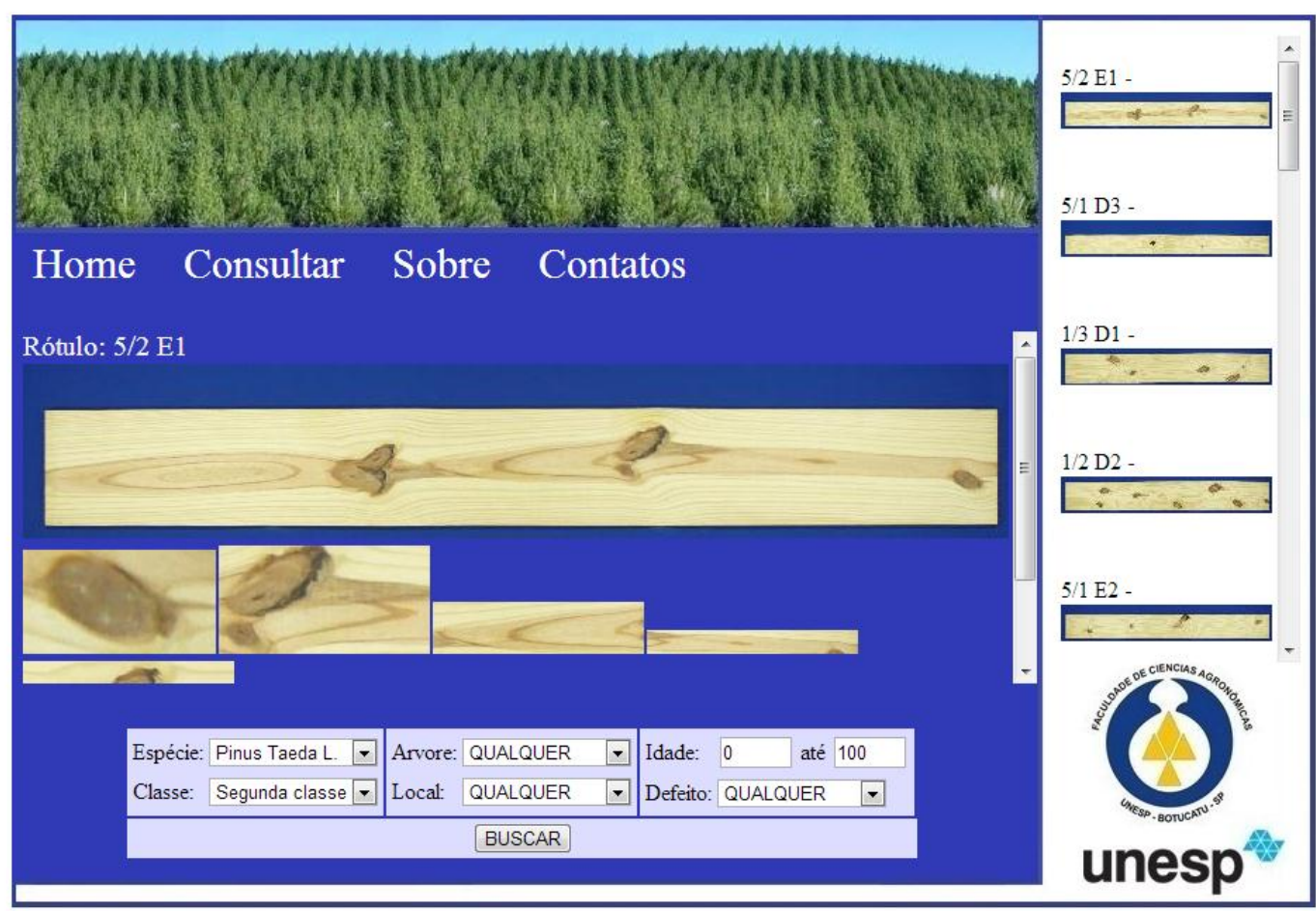

Figura 43 - Tela de consulta do sistema web

\subsubsection{Tela de detalhamento do resultado da pesquisa}

A Figura 44 ilustra a tela de detalhamento do resultado da pesquisa. Esta tela é apresentada assim que o usuário clica sobre a imagem da tábua apresentada no centro da tela de consulta da qual deseja obter mais detalhes. Essa tela traz a imagem em tamanho real, com a resolução espacial com que é adquirida originalmente no estúdio. Traz também os metadados da imagem como dimensões e dados da árvore de origem, gênero e 
espécie, ou seja, todos os dados relacionados à tábua, além de imagens dos seus defeitos, se catalogados. Na interface desta tela, é possível promover a descarga tanto da imagem da tábua como das imagens dos defeitos apresentados. Para que isso seja possível, basta clicar com o botão direito do mouse sobre a imagem que um menu suspenso surge na tela com opções para: salvar uma cópia da imagem ou copiar a imagem para área de transferência. Clicando sobre o item "Salvar imagem" do menu, basta escolher onde gravar o arquivo e atribuir-lhe um nome. Assim tem-se o arquivo da imagem digital da tábua, ou do defeito, transferido para qualquer dispositivo de armazenamento. Para a obtenção dos dados referentes à imagem apresentada no detalhamento, basta selecionar os dados apresentados com o mouse, copiá-los e colá-los em qualquer software que edite textos.

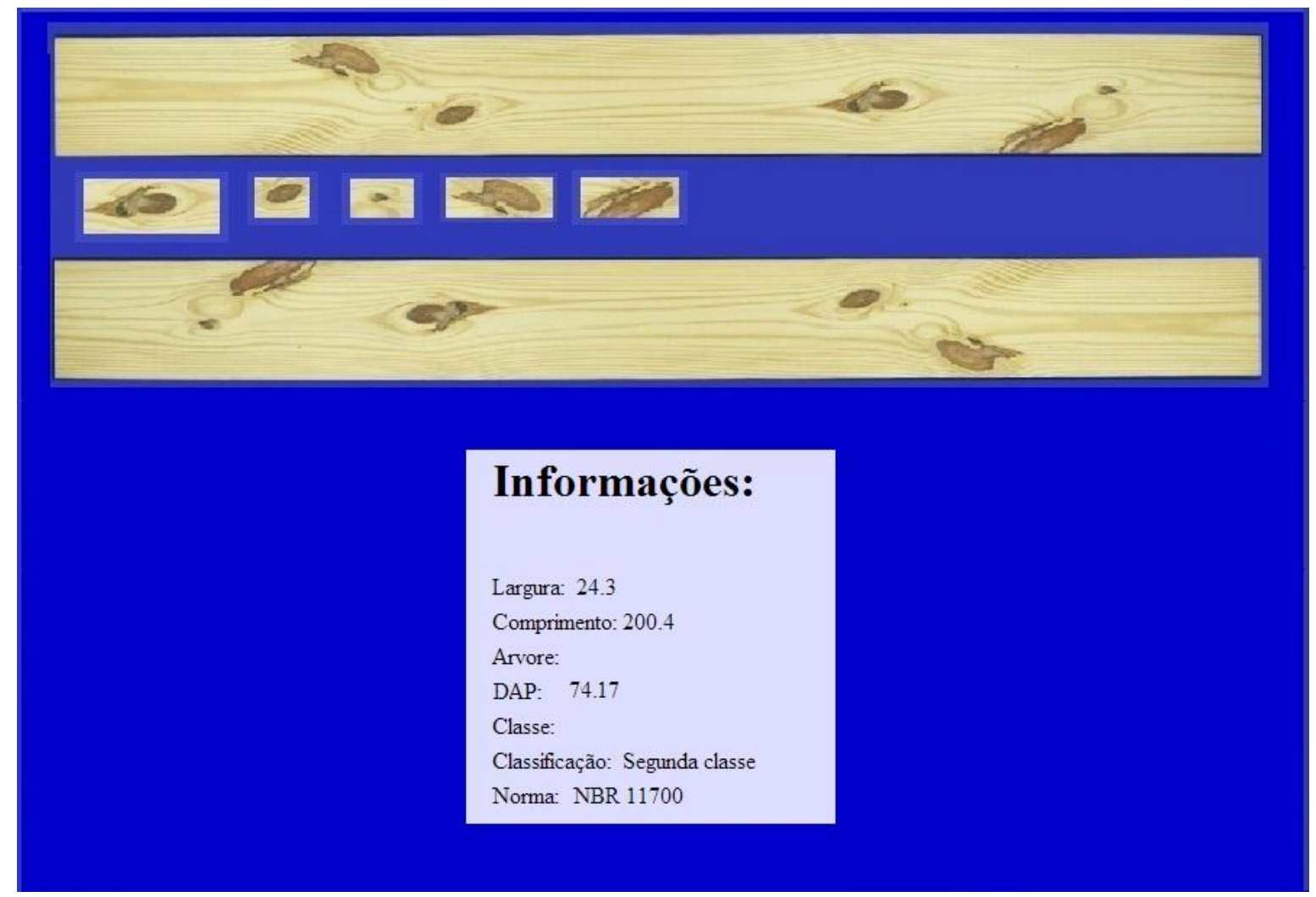

Figura 44 - Tela de detalhamento da imagem e download 


\section{CONSIDERAÇÕES FINAIS}

Tem-se, ao final desse trabalho, o banco de dados construído e povoado com uma gama significativa de imagens de tábuas e blocos de defeito, assim como o sistema computacional desenvolvido, para funcionamento em plataforma web e com as funcionalidades propostas implementadas. Os quais eram objetivos principais desse trabalho.

Entende-se que os objetivos específicos também foram alcançados dada a efetivação da caracterização das imagens das tábuas e separação de blocos de imagens das regiões com apresentação de defeitos, além de serem definidos os metadados que acompanham as imagens e implementados os campos específicos na tabela de tábuas do banco de dados para armazenar cada informação relevante referente a mesma, que por fim caracteriza a imagem, além da tabela que recebe as imagens das tábuas, construiu-se a tabela que armazena as imagens dos blocos de defeito e seu dados pertinentes.

Conseguiu-se apresentar o banco de dados associado a um sistema computacional de forma que o primeiro possa ser acessado através da internet utilizando-se o segundo, em plataforma web. Essa característica, de todo o sistema funcionar sobre plataforma web, era muito importante para o êxito projeto, pois ela garante que o acesso ao banco de dados, após o mesmo ser hospedado e disponibilizado em infraestrutura de computação específica para isso, possa dar-se de forma pública, bastando para isso o acesso do usuário a internet.

Algumas melhorias no software e adaptações no banco de dados sempre se farão necessárias e são apontadas como próximos passos para futuros projetos. 
Sistemas computadorizados revelam necessidades de adaptações somente à medida que são utilizados em larga escala. Além de algumas ferramentas que surgem, com o avanço tecnológico, na área de desenvolvimento de sistemas, sites e bancos de dados, o que acontece de forma bem rápida e dinâmica. Um pesquisador que acompanhe tais mudanças e exigências e as aplique ao sistema também seria importante para a viabilidade do projeto.

$\mathrm{Na}$ continuidade dessa linha de pesquisa propõe-se criar uma ferramenta no sistema desenvolvido para receber contribuição de imagens de outras regiões e colaboradores, a fim de obter amostras de defeitos não catalogados no presente trabalho por falta de tábuas que os apresentassem.

Além disso, e para viabilidade de tal funcionalidade, deve-se criar uma comissão para avaliar as imagens enviadas por colaboradores, os quais devem ser previamente cadastrados para garantir a origem da imagem. Essa comissão teria a incumbência de avaliar as imagens antes de inseri-las no banco de dados. Tal avaliação envolveria a verificação da resolução espacial mínima da imagem e da certificação de originalidade da amostra, bem como da idoneidade do usuário que a submeteu.

Outro andamento para esse trabalho seria a hospedagem da base de dados em um provedor mantido pela instituição para que o mesmo tenha visibilidade mundial, já que o banco de dados é veiculado por um sistema desenvolvido para plataforma web, e por isso pode ser acessado via internet a partir de qualquer computador interligado a rede no mundo.

O sistema computacional desenvolvido e o banco de dados implementado podem ser aplicados e disponibilizados para acesso público de imediato, bastando para tanto que recursos tecnológicos necessário sejam disponibilizados. $\mathrm{O}$ banco de dados possui uma gama de imagens catalogadas que certamente contribui para outros trabalhos relacionados à madeira serrada Pinus, bem como em aplicações comerciais dessas tábuas, além ter demonstrado, de imediato, sua utilidade no desenvolvimento de novas tecnologias de classificação automatizada de tábuas, mais baratas e acessíveis que as disponíveis atualmente. 


\section{REFERÊNCIAS}

ABIMCI-ASSOCIAÇÃO BRASILEIRA DA INDÚSTRIA DE MADEIRA PROCESSADA MECANICAMENTE. Estudo setorial 2008: ano base 2007. ABIMCI, 2008 .

ABNT-ASSOCIAÇÃO BRASILEIRA DE NORMAS TÉCNICAS. NBR- 11700: Madeira serrada de coníferas provenientes de reflorestamento para uso geral: classificação. Rio de Janeiro, $1991 b$.

ABNT-ASSOCIAÇÃO BRASILEIRA DE NORMAS TÉCNICAS. NBR- 12297: Madeira serrada de coníferas provenientes de reflorestamento para uso geral: Medição e quantificação de defeitos. Rio de Janeiro, 1991a.

ABNT-ASSOCIAÇÃO BRASILEIRA DE NORMAS TÉCNICAS. NBR- 12498: Madeira serrada de coníferas provenientes de reflorestamento para uso geral: Dimensões e lotes. Rio de Janeiro, 1991b.

ABPM-ASSOCIAÇÃO BRASILEIRA DE PRODUTORES DE MADEIRAS. Pinus: catálogo de normas de madeira serrada. Curitiba, 2001. 34 p.

ABRAF-ASSOCIAÇÃO BRASILEIRA DE PRODUTORES DE FLORESTAS PLANTADAS. Anuário estatístico da ABRAF 2012. Ano base 2011. Brasília, 2010, $140 \mathrm{P}$

APPLICATION SERVERS. Servidores de Aplicações. Disponível em: <www.iweb.com.br/iweb/pdfs/20031008-appservers-01.pdf >. Acessado em: 03 mai. 2013.

BALLARIN, A. W.; PALMA, H. A. L.. Resistência e rigidez da Madeira Pinus. Revista da Madeira, agosto: 38- 42, 2004.

BERNI, C. A.; BOLZA, E.; CHRISTENSEN, F. J.. South american timbers: the characteristics, properties and uses of 190 species. Melbourne: Ivory House, 229 p, 1979. 
BUYENS, J. Desenvolvendo banco de dados na web. 1 ed. São Paulo: Editora Makron Books do Brasil, 2001. 545 p.

CRUZ, E. S. et al. Comparação de classificadores de imagens digitais na determinação da cobertura do solo. Engenharia Agrícola, Viçosa, v. 28, n. 2, p. 237-244, 2008.

DATE, C.J. Introdução a sistemas de banco de dados. São Paulo: Editora Campus. 2004. 900 p. ISBN 85-352-1273-6.

DEITEL, H. M. XML Como programar. 1 ed. Porto Alegre: Editora Bookman, 2001. $953 \mathrm{p}$.

FRANÇA, B. M. Banco de dados multimídia. Disponível em: <http://www.inf.ufrgs.br / clesio/cmp151/cmp15120021/artigo_montgomery.pdf> Acesso em: 2 ago. 2012.

GILL, T.; GILLILAND, A. J.; WHALEN, M.; WOODLEY, M. S. Introduction to metadata. Disponível em: <http://www.getty.edu/research/publications/electronicpubli cations/intrometa data/index.html>. Acesso em: 23 jan. 2013.

GOMES, J.; VELHO, L. Computação gráfica. Rio de Janeiro: Instituto de Matemática Pura e Aplicada, 1998. v. 1.

GOMES, J. G. et al. Desenvolvimento e avaliação de um protótipo classificador de tábuas usando técnicas de visão artificial. Revista Árvore, Viçosa, v. 32, n. 5, p. 949959, 2008.

GONZALEZ, R.C.; WOODS, R.E. Processamento de imagens digitais. São Paulo: Edgard Blucher, 2000. 509 p.

HORSTMANN, C. Conceitos de programação com o essencial de Java. 3 ed. Porto Alegre: Editora Bookman, 2003. 779 p.

JAIMES, A.; CHRISTEL, M.; SÉBASTIEN, G., ET AL. Multimedia information retrieval: What is it, and why isn't anyone using it?. Singapura: ACM, 2005. 398 p.

KAUPPINEN, H. Development of a color machine vision method for wood surface inspection. 1999. 133f. Dissertation (Master in Electrical of Engineering)-University of Oulu, Oulu, 1999.

KHOURY Jr., J.K.; PINTO, F.A.C.; QUIEROZ, D.N.; DELLA LUCIA, R.M.; RESENDE, R.C. Redes neurais para reconhecimento de defeitos de madeira serrada de eucalipto em imagens digitais. Scientia Florestalis, Piracicaba, n. 70, p. 85-96, 2006.

KLINE, D. E.; SURAK, C.; ARAMAN, P. A.. Automated hardwood lumber grading utilizing a multiple sensor machine vision technology. Computers and electronics in agriculture, n.41, p.139-155, 2003.

KOIVO, A. J.; KIM, C. W. Automatic classification of surface defects on red oak boards. Forest Products Journal, Madison, v. 39, n. 9, p. 22-30, 1989. 
KRONKA, F. J. N.; BERTOLANI, F.; PONCE, R.H. A cultura do Pinus no Brasil. Páginas e Letras, 2005. 156 p.

LARMAN, C. Utilizando UML e padrões. 1 ed. Porto Alegre: Editora Bookman, 2005. 697

LEITE, M. Técnicas de programação: Uma abordagem moderna. 1 ed. Rio de Janeiro: Editora Brasport, 2006. 399 p.

MEDINA, M., FERTIG, C. Algoritmos e programação - Teoria e prática. São Paulo. Novatec Editora, 2005. Disponível em: http://186.202.25.177/livros/algoritmos/capitulo 857522073X.pdf>. Acessado em: 25 abr. 2013.

MySQL, Manual de referência do MySQL 5.5. Disponível em: http://dev.mysql.com /doc/refman/5.5/en/introduction.html. Acessado em: 02 mai. 2013.

OLIVEIRA, L. E. S. et al. Inspeção automática de defeitos em madeiras de Pinus usando visão computacional. Revista de Informática Teórica e Aplicada, Porto Alegre, v. 25, n. 2, p. 203-217, 2008.

QUOIRIN, N. S. R. Diagnóstico de defeitos em madeira por tomografia de raios- X. 2004. 142 f. Dissertação (Mestrado em Engenharia de Materiais e Processos)-Universidade Federal do Paraná, Paraná, 2004.

RALL, R. Processamento de imagens digitais para detecção e quantificação de defeitos na madeira serrada de coníferas de reflorestamento de uso não estrutural. 2010. 126 f. Tese (Doutorado em Agronomia)-Universidade Estadual Paulista, São Paulo, 2010.

RALL, R.; BALLARIN, A. W. Influência das características dos anéis de crescimento na densidade, resistência e rigidez da madeira de Pinus taeda L. Energia na Agricultura, Botucatu, v. 22, n. 2, p. 81-93, 2007.

SHIMIZU, J. Y.. Pínus na silviculura brasileira. Revista da madeira, agosto:22-28, 2004.

SEVERO, C. NetBeans IDE 4.1. Rio de Janeiro: BRASPORT Livros e Multimídia Ltda, 2005. $245 \mathrm{p}$.

SIMÕES, J. W.; BRANDI, R. M.; LEITE, N. B.; BALLONI, E. A.. Formação, manejo e exploração de florestas com espécies de rápido crescimento. Brasília, IBDF, 1981. 131 p.

SOUZA, S. E. V. Novidades do GlassFish 3.1. Disponível em <http://www. devmedia.com.br/articles/viewcomp_forprint.asp?comp=21124 >. Acessado em 05 abr. 2013.

SPÓSITO M. B. Dinâmica temporal e espacial da mancha preta (Guignardia citricarpa) e quantificação dos danos causados à cultura dos citros. $2003.112 \mathrm{f}$. Tese (Doutorado em Agronomia) - Escola Superior de Agricultura Luiz de Queiroz, Universidade de São Paulo, Piracicaba, 2003. 
TEIXEIRA, E. F.; CICERO, S. M.; NETO, D. D. Análise de imagens digitais na avaliação de plântulas de milho. Revista Brasileira de Sementes, Pelotas, v. 28, n. 2, p. 159-167, 2006.

TITTEL, E. Rede de computadores (Coleção Schaum). 1 ed. Porto Alegre: Editora Bookman, 2002. 258 p.

TRIGO, T. Equipamento fotográfico: teoria e prática. São Paulo: Editora Senac, 2005. 260p.

WARKEN, R. Netbeans 7.1 Early Release. 2012. Apresenta Especificações sobre Netbeans. Disponível em: <http://www.javafree.org/news/view.jf?idNew=1274>. Acesso em: 21 abr. 2013.

ZABOT, L. et al. Uso de imagens digitais para avaliação de plântulas de feijão. Revista Brasileira de Sementes, Pelotas, v. 30, n. 2, p. 184-192, 2008.

ZANETI JUNIOR, L. A. Sistemas de informação baseados na tecnologia web: um estudo sobre seu desenvolvimento. 1 ed. São Paulo: Editora Campus, 2003. 189 p. 
APÊNDICE 1

Resultados da classificação visual de parte das tábuas dos grupos 2 e 3 a partir de suas imagens 
Resultado da classificação manual das tábuas do grupo 2 e 3, aplicada sobre as imagens digitais das tábuas.

\begin{tabular}{|c|c|c|c|c|c|}
\hline $\begin{array}{l}\text { Num. } \\
\text { Código }\end{array}$ & $\begin{array}{l}\text { Comprimento } \\
\text { (cm) }\end{array}$ & $\begin{array}{l}\text { Largura } \\
\text { (cm) }\end{array}$ & Rotulo & Face & $\begin{array}{c}\text { Classificação } \\
\text { Visual da Imagem }\end{array}$ \\
\hline 247 & 248 & 24,5 & $1 \_5 \mathrm{C} 1$ & 1 & Primeira \\
\hline 248 & 248 & 24,5 & 1_5 C1 & 2 & Primeira \\
\hline 249 & 248 & 25,0 & 1_5 C2 & 1 & Segunda \\
\hline 250 & 248 & 25,0 & $1 \_5 \mathrm{C} 2$ & 2 & Primeira \\
\hline 253 & 249 & 23,0 & 1_5 D1 & 1 & Terceira \\
\hline 254 & 249 & 23,0 & 1_5 D1 & 2 & Terceira \\
\hline 255 & 249 & 23,0 & 1_5 D2 & 1 & Segunda \\
\hline 256 & 249 & 23,0 & 1_5 D2 & 2 & Segunda \\
\hline 261 & 248 & 23,0 & 1_6 C1 & 1 & Primeira \\
\hline 262 & 248 & 23,0 & 1_6 C1 & 2 & Segunda \\
\hline 263 & 248 & 23,0 & $1 \_6 \mathrm{C} 2$ & 1 & Primeira \\
\hline 264 & 248 & 23,0 & $1 \_6 \mathrm{C} 2$ & 2 & Segunda \\
\hline 265 & 248 & 23,5 & 1_6 C3 & 1 & Primeira \\
\hline 266 & 248 & 23,5 & 1_6 C3 & 2 & Segunda \\
\hline 267 & 248 & 19,5 & 1_6 D1 & 1 & Extra \\
\hline 268 & 248 & 19,5 & 1_6 D1 & 2 & Extra \\
\hline 269 & 248 & 14,5 & 1_6 D2 & 1 & Primeira \\
\hline 270 & 248 & 14,5 & 1_6 D2 & 2 & Primeira \\
\hline 273 & 248 & 14,5 & 1_6 E2 & 1 & Primeira \\
\hline 274 & 248 & 14,5 & 1_6 E2 & 2 & Extra \\
\hline 275 & 251 & 24,5 & 1_7 C1 & 1 & Primeira \\
\hline 276 & 251 & 24,5 & $1 \_7 \mathrm{C} 1$ & 2 & Primeira \\
\hline 277 & 251 & 24,5 & 1_7 C2 & 1 & Extra \\
\hline 278 & 251 & 24,5 & 1_7 C2 & 2 & Primeira \\
\hline 285 & 251 & 20,5 & 1_7 E1 & 1 & Primeira \\
\hline 286 & 251 & 20,5 & 1_7 E1 & 2 & Segunda \\
\hline 287 & 251 & 14,0 & 1_7 E2 & 1 & Extra \\
\hline 288 & 251 & 14,0 & 1_7 E2 & 2 & Extra \\
\hline 293 & 248 & 16,5 & $1 \_8 \mathrm{C} 2$ & 1 & Segunda \\
\hline 294 & 248 & 16,5 & $1 \_8 \mathrm{C} 2$ & 2 & Segunda \\
\hline 303 & 247 & 24,5 & 2_2 D1 & 1 & Terceira \\
\hline 304 & 247 & 24,5 & 2_2 D1 & 2 & Terceira \\
\hline 307 & 247 & 24,0 & 2_2 E2 & 1 & Super \\
\hline 308 & 247 & 24,0 & 2_2 E2 & 2 & Extra \\
\hline 309 & 249 & 29,0 & $2 \_3 \mathrm{C} 1$ & 1 & Primeira \\
\hline 310 & 249 & 29,0 & 2_3 C1 & 2 & Primeira \\
\hline 319 & 249 & 19,5 & 2_3 E3 & 1 & Super \\
\hline 320 & 249 & 19,5 & 2_3 E3 & 2 & Primeira \\
\hline
\end{tabular}




\begin{tabular}{|c|c|c|c|c|c|}
\hline 321 & 251 & 22,0 & 2_4 D2 & 1 & Primeira \\
\hline 322 & 251 & 22,0 & 2_4 D2 & 2 & Primeira \\
\hline 325 & 249 & 28,5 & 2_5 C1 & 1 & Extra \\
\hline 326 & 249 & 28,5 & 2_5 C1 & 2 & Extra \\
\hline 327 & 249 & 28,5 & 2_5 C2 & 1 & Extra \\
\hline 328 & 249 & 28,5 & $2 \_5 \mathrm{C} 2$ & 2 & Segunda \\
\hline 329 & 249 & 29,0 & 2_5 C3 & 1 & Segunda \\
\hline 330 & 249 & 29,0 & $2 \_5 \mathrm{C} 3$ & 2 & Segunda \\
\hline 335 & 249 & 0,0 & 2_5 E1 & 1 & Primeira \\
\hline 336 & 249 & 0,0 & $2 \_5 \mathrm{E} 1$ & 2 & Segunda \\
\hline 347 & 249 & 19,5 & 2_7 D1 & 1 & Super \\
\hline 348 & 249 & 19,5 & 2_7 D1 & 2 & Extra \\
\hline 349 & 249 & 19,0 & 2_8 D1 & 1 & Extra \\
\hline 350 & 249 & 19,0 & 2_8 D1 & 2 & Primeira \\
\hline 365 & 250 & 24,5 & 3_3 E2 & 1 & Primeira \\
\hline 366 & 250 & 24,5 & 3_3 E2 & 2 & Primeira \\
\hline 367 & 250 & 23,0 & 3_4 E1 & 1 & Segunda \\
\hline 368 & 250 & 23,0 & 3_4 E1 & 2 & Segunda \\
\hline 369 & 250 & 13,0 & 3_4 E3 & 1 & Primeira \\
\hline 370 & 250 & 13,0 & 3_4 E3 & 2 & Primeira \\
\hline 371 & 251 & 19,5 & $3 \_5 \mathrm{D} 1$ & 1 & Extra \\
\hline 372 & 251 & 19,5 & $3 \_5$ D1 & 2 & Extra \\
\hline 373 & 251 & 16,0 & $3 \_5 \mathrm{D} 2$ & 1 & Primeira \\
\hline 374 & 251 & 16,0 & $3 \_5 \mathrm{D} 2$ & 2 & Primeira \\
\hline 375 & 251 & 22,0 & 3_5 E1 & 1 & Primeira \\
\hline 376 & 251 & 22,0 & $3 \_5 \mathrm{E} 1$ & 2 & Extra \\
\hline 377 & 251 & 16,5 & 3_5 E2 & 1 & Primeira \\
\hline 378 & 251 & 16,5 & 3_5 E2 & 2 & Primeira \\
\hline 383 & 247 & 23,0 & 3_6 E1 & 1 & Super \\
\hline 384 & 247 & 23,0 & 3_6 E1 & 2 & Primeira \\
\hline 385 & 247 & 19,0 & 3_6 E2 & 1 & Extra \\
\hline 386 & 247 & 19,0 & 3_6 E2 & 2 & Primeira \\
\hline 387 & 252 & 22,5 & 3_7 C1 & 1 & Primeira \\
\hline 388 & 252 & 22,5 & 3_7 C1 & 2 & Primeira \\
\hline 393 & 252 & 17,5 & 3_7 D1 & 1 & Primeira \\
\hline 394 & 252 & 17,5 & 3_7 D1 & 2 & Primeira \\
\hline 395 & 252 & 21,0 & $3 \_7$ D2 & 1 & Segunda \\
\hline 396 & 252 & 21,0 & 3_7 D2 & 2 & Primeira \\
\hline 401 & 251 & 20,0 & 3_8 C3 & 1 & Segunda \\
\hline 402 & 251 & 20,0 & 3_8 C 3 & 2 & Segunda \\
\hline 407 & 251 & 19,5 & 3_8 E1 & 1 & Primeira \\
\hline 408 & 251 & 19,5 & 3_8 E1 & 2 & Primeira \\
\hline
\end{tabular}


APÊNDICE 2

Resultado da classificação das tábuas do grupo 1, por processo manual e via software SAIMP 
Resultado da classificação das tábuas do grupo 1, manual e via software

\begin{tabular}{|c|c|c|c|c|c|}
\hline Num. & $\begin{array}{l}\text { Referência } \\
\text { da tábua }\end{array}$ & $\begin{array}{c}\text { Comprimento } \\
(\mathbf{m m})\end{array}$ & $\begin{array}{c}\text { Largura } \\
(\mathbf{m m})\end{array}$ & $\begin{array}{c}\text { Classificação } \\
\text { Manual }\end{array}$ & $\begin{array}{l}\text { Classificação } \\
\text { Software }\end{array}$ \\
\hline 1 & $5 / 2 \mathrm{E} 1$ & 2004 & 243 & Segunda & Segunda \\
\hline 2 & 1/3 E1 & 2004 & 290 & Primeira & Primeira \\
\hline 3 & $6 / 2 \mathrm{E} 2$ & 2004 & 242 & Segunda & Primeira \\
\hline 4 & 5/1 D3 & 2004 & 195 & Segunda & Segunda \\
\hline 5 & $1 / 3 \mathrm{D} 1$ & 2004 & 290 & Segunda & Segunda \\
\hline 6 & 3/1 E1 & 2004 & 241 & Segunda & Primeira \\
\hline 7 & $1 / 2 \mathrm{D} 2$ & 2005 & 289 & Segunda & Segunda \\
\hline 8 & 5/1 E2 & 2004 & 241 & Segunda & Segunda \\
\hline 9 & 4/1 E1 & 2004 & 248 & Primeira & Primeira \\
\hline 10 & $1 / 1 \mathrm{E} 4$ & 2004 & 240 & Primeira & Segunda \\
\hline 11 & 3/1 D1 & 2004 & 241 & Primeira & Primeira \\
\hline 12 & 6/1 D1 & 2004 & 242 & Segunda & Segunda \\
\hline 13 & 2/3 D1 & 2004 & 245 & Primeira & Primeira \\
\hline 14 & 1/2 E1 & 2004 & 297 & Segunda & Segunda \\
\hline 15 & $5 / 2 \mathrm{D} 1$ & 2004 & 244 & Primeira & Primeira \\
\hline 16 & 5/3 E1 & 2004 & 243 & Primeira & Primeira \\
\hline 17 & 4/3 E1 & 2004 & 243 & Super & Extra \\
\hline 18 & $5 / 2 \mathrm{E} 2$ & 2004 & 242 & Segunda & Segunda \\
\hline 19 & 2/3 E1 & 2003 & 244 & Primeira & Primeira \\
\hline 20 & 3/2 E1 & 2004 & 245 & Super & Super \\
\hline 21 & 4/4 E1 & 2004 & 170 & Primeira & Extra \\
\hline 22 & 3/3 E1 & 2004 & 193 & Super & Super \\
\hline 23 & 2/2 D1 & 2004 & 244 & Super & Super \\
\hline 24 & 5/4 E1 & 2004 & 195 & Super & Super \\
\hline 25 & $1 / 3 \mathrm{D} 2$ & 2004 & 243 & Primeira & Primeira \\
\hline 26 & 3/1 E2 & 2004 & 240 & Segunda & Segunda \\
\hline 27 & 1/1 E1 & 2004 & 304 & Segunda & Segunda \\
\hline 28 & 5/1 D1 & 2005 & 291 & Segunda & Segunda \\
\hline 29 & $6 / 1 \mathrm{E} 1$ & 2004 & 290 & Primeira & Primeira \\
\hline 30 & 1/1 D2 & 2004 & 290 & Segunda & Segunda \\
\hline 31 & $4 / 2 \mathrm{E} 1$ & 2004 & 242 & Super & Super \\
\hline 32 & 6/3 E3 & 2003 & 138 & Super & Super \\
\hline 33 & $5 / 1 \mathrm{D} 2$ & 2004 & 240 & Primeira & Primeira \\
\hline 34 & 2/2 D2 & 2004 & 196 & Super & Super \\
\hline 35 & 2/1 E3 & 2004 & 168 & Primeira & Primeira \\
\hline 36 & 6/2 D1 & 2005 & 194 & Segunda & Segunda \\
\hline 37 & $6 / 2 \mathrm{E} 3$ & 2004 & 195 & Primeira & Primeira \\
\hline 38 & $1 / 2 \mathrm{E} 2$ & 2004 & 192 & Primeira & Primeira \\
\hline 39 & 6/3 D1 & 2005 & 196 & Primeira & Extra \\
\hline 40 & 1/1 D1 & 2004 & 326 & Segunda & Segunda \\
\hline
\end{tabular}




\begin{tabular}{|c|c|c|c|c|c|}
\hline 41 & $2 / 1 \mathrm{D} 4$ & 2004 & 166 & Primeira & Primeira \\
\hline 42 & $6 / 2 \mathrm{D} 2$ & 2004 & 166 & Primeira & Primeira \\
\hline 43 & 1/1 D3 & 2005 & 239 & Segunda & Segunda \\
\hline 44 & 4/1 E2 & 2004 & 247 & Super & Super \\
\hline 45 & 6/1 E2 & 2004 & 241 & Segunda & Segunda \\
\hline 46 & $1 / 2 \mathrm{D} 3$ & 2004 & 241 & Segunda & Segunda \\
\hline 47 & 3/3 D1 & 2004 & 296 & Primeira & Primeira \\
\hline 48 & $2 / 2 \mathrm{E} 1$ & 2004 & 244 & Super & Super \\
\hline 49 & 2/1 E1 & 2004 & 290 & Super & Super \\
\hline 50 & 1/1 E3 & 2004 & 301 & Segunda & Segunda \\
\hline 51 & $5 / 2 \mathrm{D} 3$ & 2004 & 167 & Segunda & Segunda \\
\hline 52 & $3 / 2 \mathrm{E} 3$ & 2004 & 165 & Primeira & Primeira \\
\hline 53 & 4/1 D1 & 2004 & 195 & Super & Super \\
\hline 54 & 6/3 E1 & 2004 & 195 & Super & Super \\
\hline 55 & $6 / 1 \mathrm{E} 4$ & 2004 & 133 & Primeira & Primeira \\
\hline 56 & 2/1 D2 & 2004 & 242 & Primeira & Primeira \\
\hline 57 & 4/1 D2 & 2004 & 138 & Super & Super \\
\hline 58 & 4/3 D1 & 2005 & 195 & Primeira & Primeira \\
\hline 59 & 6/4 E1 & 2004 & 138 & Primeira & Primeira \\
\hline 60 & $1 / 2 \mathrm{D} 4$ & 2004 & 165 & Primeira & Primeira \\
\hline 61 & 3/1 D3 & 2004 & 166 & Segunda & Segunda \\
\hline 62 & 1/4 E1 & 2004 & 196 & Segunda & Segunda \\
\hline 63 & $6 / 3 \mathrm{D} 2$ & 2005 & 138 & Primeira & Primeira \\
\hline 64 & $5 / 3 \mathrm{E} 4$ & 2004 & 137 & Primeira & Primeira \\
\hline 65 & 4/3 D2 & 2004 & 167 & Primeira & Primeira \\
\hline 66 & $4 / 2 \mathrm{D} 2$ & 2004 & 166 & Primeira & Primeira \\
\hline 67 & 4/4 D1 & 2004 & 195 & Super & Super \\
\hline 68 & 1/4 D2 & 2004 & 195 & Primeira & Primeira \\
\hline 69 & $1 / 4 \mathrm{D} 3$ & 2004 & 139 & Primeira & Primeira \\
\hline 70 & 6/1 D3 & 2004 & 166 & Primeira & Primeira \\
\hline 71 & 1/3 D3 & 2004 & 195 & Primeira & Primeira \\
\hline 72 & 5/1 D4 & 2004 & 136 & Primeira & Primeira \\
\hline 73 & 4/3 E2 & 2004 & 196 & Super & Super \\
\hline 74 & 2/2 E3 & 2004 & 194 & Primeira & Primeira \\
\hline 75 & 5/3 D1 & 2004 & 194 & Primeira & Primeira \\
\hline 76 & 2/1 D1 & 2004 & 290 & Primeira & Primeira \\
\hline 77 & 1/1 E5 & 2004 & 192 & Segunda & Segunda \\
\hline 78 & 3/1 D2 & 2004 & 193 & Segunda & Segunda \\
\hline 79 & 1/4 E2 & 2005 & 137 & Segunda & Extra \\
\hline 80 & 5/1 E3 & 2005 & 167 & Segunda & Segunda \\
\hline 81 & 3/3 D1 & 2004 & 168 & Primeira & Primeira \\
\hline 82 & 3/2 D2 & 2004 & 166 & Primeira & Super \\
\hline 83 & 2/1 E1 & 2006 & 291 & Primeira & Primeira \\
\hline 84 & 1/1 E2 & 1959 & 303 & Primeira & Primeira \\
\hline
\end{tabular}

